\title{
Levantamento do potencial de regeneração natural

\author{
de florestas nativas \\ nas diferentes regiões do \\ estado do Espírito Santo
}

Marcelo Simonelli Sebastião Venâncio Martins Mário Sartori

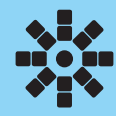

Edifes

aet if 8 
Levantamento do potencial de regeneração natural de florestas nativas nas diferentes regiões do estado do Espírito Santo 


\author{
Marcelo Simonelli \\ Sebastião Venâncio Martins \\ Mário Sartori
}

Frederico Lopes Raposo Filho

Gilmar Dadalto

Marcos Lima Pereira

\title{
Levantamento do potencial de regeneração natural de florestas nativas nas diferentes regiões do estado do Espírito Santo
}




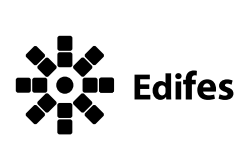

Editora do Instituto Federal de Educação, Ciência e Tecnologia do Espírito Santo R. Barão de Mauá, nº 30 - Jucutuquara 29040-689 - Vitória - ES

www.edifes.ifes.edu.br| editora@ifes.edu.br

Reitor: Jadir José Pela

Pró-Reitor de Administração e Orçamento: Lezi José Ferreira

Pró-Reitor de Desenvolvimento Institucional: Luciano de Oliveira Toledo

Pró-Reitora de Ensino: Adriana Pionttkovsky Barcellos

Pró-Reitor de Extensão: Renato Tannure Rotta de Almeida

Pró-Reitor de Pesquisa e Pós-Graduação: André Romero da Silva

Coordenador da Edifes: Adonai José Lacruz

\section{Conselho Editorial}

Aldo Rezende $•$ Ediu Carlos Lopes Lemos $•$ Felipe Zamborlini Saiter $•$ Francisco de Assis Boldt - Glória Maria de F. Viegas Aquije • Karine Silveira • Maria das Graças Ferreira Lobino

- Marize Lyra Silva Passos • Nelson Martinelli Filho • Pedro Vitor Morbach Dixini

- Rossanna dos Santos Santana Rubim • Viviane Bessa Lopes Alvarenga

\section{Produção editorial}

Projeto Gráfico: Assessoria de Comunicação Social do Ifes

Revisão de texto: Eliane Silva

Diagramação e epub: Know-How Desenvolvimento Editorial

Capa: Romério Damascena

Imagem de capa: Acervo da autoria

Dados internacionais de Catalogação na Publicação

\footnotetext{
L655 Levantamento do potencial de regeneração natural de florestas nativas nas diferentes regiões do estado do Espírito Santo [recurso eletrônico] / Marcelo Simonelli... [et al.]. - Vitória, ES : Edifes, 2021. 1 recurso on-line : ePub.

Vários autores.

ISBN: 978-65-86361-98-8 (e-book).

1. Florestas - Reprodução. 2. Florestas - Espírito Santo (Estado). I. Simonelli, Marcelo. II. Martins, Sebastião Venâncio. III. Sartori, Mário. IV. Raposo Filho, Frederico Lopes. V. Dadalto, Gilmar. VI. Pereira, Marcos Lima. VII. Título.
}

CDD $22-577.38152$

Bibliotecária Rossanna dos Santos Santana Rubim - CRB6- ES 403

(c) 2021 Instituto Federal do Espírito Santo

Todos os direitos reservados.

É permitida a reprodução parcial desta obra, desde que citada a fonte.

O conteúdo dos textos é de inteira responsabilidade do autor. 


\section{Sumário}

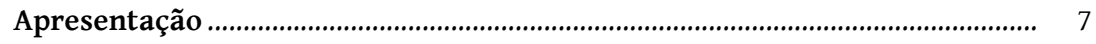

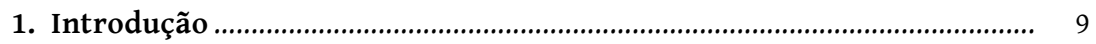

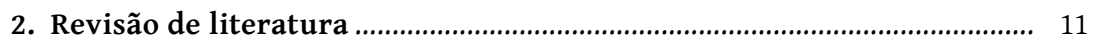

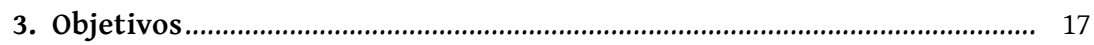

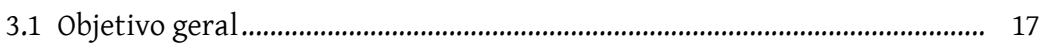

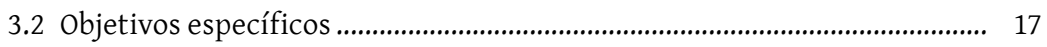

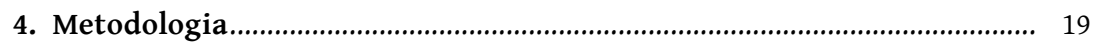

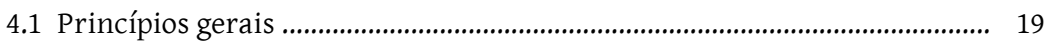

4.2 Determinação da dimensão amostral.......................................................... 19

4.3 Levantamento do número de fragmentos florestais regenerados.............. 21

4.4 Cálculo estatístico amostral ........................................................................... 22

4.5 Estudo dos fragmentos florestais através de técnicas de

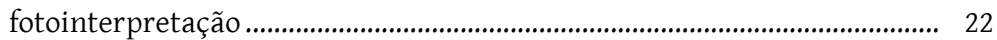

4.6 Zoneamento para regeneração florestal natural do estado

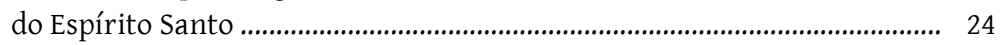

4.7 Levantamento de dados em campo ........................................................... 31

4.8 Análises estatísticas................................................................................... 32

4.9 Classificação das zonas do Espírito Santo de acordo com o potencial de regeneração natural ...................................................................................... 32

4.10 Síntese da metodologia............................................................................ 35 


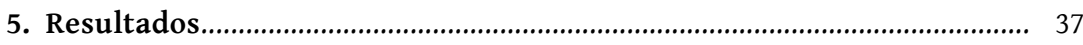

5.1 Fatores que influenciaram a regeneração natural...................................... 37

5.1.1 Distância das florestas fornecedoras de propágulos (florestas matrizes)......................................................................................... 37

5.1.2 Estrutura e funcionalidade das florestas matrizes............................. 38

5.1.3 Existência de bancos de sementes no solo .......................................... 38

5.1.4 Diferença de cota altimétrica entre a floresta matriz e a área regenerada .................................................................................... 39

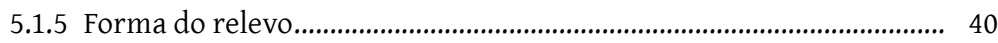

5.1.6 Presença de espécies-problema ......................................................... 42

5.1.7 Ações antrópicas .............................................................................. 42

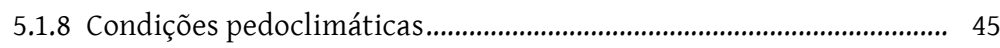

5.2 Dados das florestas regeneradas e florestas fornecedoras

de propágulos (matrizes) ................................................................................. 45

5.3 Classificação das Zonas de acordo com o potencial de Regeneração

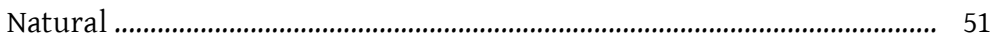

5.4 Caracterização florística das áreas regeneradas do Espírito Santo............ 54

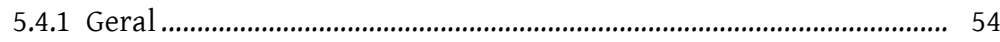

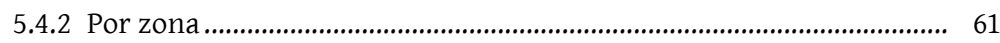

5.4.2.1 Zona Extremo Norte ............................................................. 61

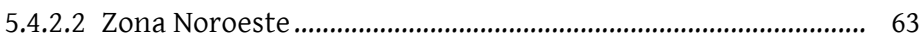

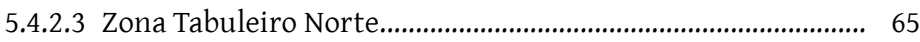

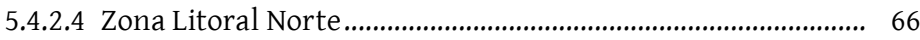

5.4.2.5 Zona Extremo Oeste Seco .................................................... 68

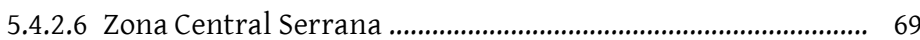

5.4.2.7 Zona Transição Metropolitana/Central Serrana.................... 70

5.4.2.8 Zona Metropolitana ................................................................... 72

5.4.2.9 Zona Tabuleiro Sul/Extremo Sul Baixo ................................... 74

5.4.2.10 Zona Central Sul ..................................................................... 75

5.4.2.11 Zona Extremo Sul Acidentado............................................... 75

5.4.2.12 Zona Polo Caparaó.................................................................. 77

6. Principais constatações, conclusões e recomendações ............................ 79

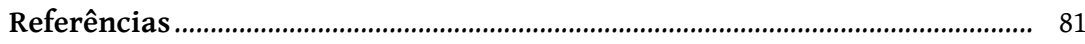

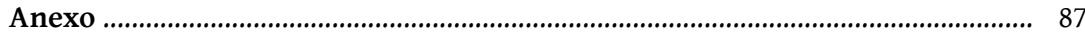




\section{Apresentação}

A presente obra é o resultado do projeto intitulado "Levantamento do potencial de regeneração natural de florestas nativas nas diferentes regiões do Estado do Espírito Santo", desenvolvido pelo Centro de Desenvolvimento do Agronegócio (CEDAGRO) em articulação com pesquisadores do Instituto Federal do Espírito Santo (IFES), Universidade Federal de Viçosa (UFV), Universidade Federal do Espírito Santo (UFES), Secretaria de Estado da Agricultura, Abastecimento, Aquicultura e Pesca do Espírito Santo (SEAG), Instituto Capixaba de Pesquisa, Assistência Técnica e Extensão Rural (INCAPER) e Instituto de Defesa Agropecuária e Florestal do Espírito Santo (IDAF). O referido projeto foi financiado pela Fibria e pela Rodosol.

A obra apresenta um estudo minucioso do potencial de regeneração natural das florestas do Espírito Santo e vem ao encontro das questões de qualidade da restauração, bem como de sua aplicabilidade, tendo em vista que a restauração de áreas através do processo convencional de reflorestamento apresenta alto custo e, em muitos casos, baixa eficiência no estabelecimento das mudas, o que dificulta a aceitação por parte dos produtores rurais. Visa prover os técnicos de uma ferramenta para o diagnóstico local da viabilidade de ocorrência de regeneração natural de floresta em determinada área. 0 objetivo principal foi levantar o potencial de regeneração natural nas diferentes regiões do Estado do Espírito Santo, visando contribuir no processo de aumento da cobertura florestal nativa de forma simples, eficiente, com baixo custo e maior aceitação pelos produtores rurais e outros componentes do setor florestal capixaba. Também subsidiará decisões relativas ao uso de tecnologias apropriadas para a restauração florestal, com foco na otimização dos 
recursos, funções ecológicas e redução dos custos da restauração. Será também uma ferramenta para a utilização no setor público e na iniciativa privada, visando à elaboração de propostas de restauração florestal através da regeneração natural.

No final do livro, são resumidas as principais constatações, conclusões e recomendações do estudo, fornecendo, desta forma, dados e informações que servirão de base para a elaboração de estratégias de restauração florestal dos programas e ações de políticas públicas e privadas relativas ao tema. 


\section{1 \\ Introdução}

O Estado do Espírito Santo sofreu um processo acelerado e indiscriminado de desmatamento, restando atualmente cerca de $11 \%$ de florestas de origem nativa primária e secundária nos seus estágios médio e avançado de regeneração (SOS Mata Atlântica, 2010), que se encontram, em sua maior parte, em manchas dispersas, compondo pequenos fragmentos florestais.

No entanto, apesar do baixo percentual de cobertura florestal natural, existe uma grande variabilidade nas diferentes regiões do Estado, oscilando de 1\% a 41\%. Os menores índices estão concentrados na Região Norte e em municípios do litoral sul, enquanto a Região Serrana é a que possui os maiores percentuais de florestas naturais.

Com o objetivo de reverter esse cenário atual, a iniciativa pública e a iniciativa privada estadual vêm desenvolvendo alguns programas, projetos e ações com foco na restauração florestal, reflorestamentos e desenvolvimento de sistemas agroflorestais, todos buscando atingir a ampliação da cobertura florestal natural do Estado.

No Brasil, a partir da década de 1980, iniciou-se uma frente de reação ao processo de degradação ambiental, cujo foco é a restauração dos ecossistemas já degradados (MARTINS, 2012). Paralelamente, ocorreu uma mudança na forma de se fazer restauração, embasada principalmente nos aspectos de sucessão ecológica. Com isso, projetos estritamente agronômicos e silviculturais vêm sendo substituídos por projetos com enfoque na ecologia vegetal e na ecologia da restauração, com prioridade para a restauração da resiliência dos ecossistemas.

Atualmente, as técnicas e metodologias que buscam a restauração florestal visam à maximização da resiliência potencial do ambiente em estudo, na tentativa de favorecer os mecanismos naturais que permitem a reação da natureza (CAMPELLO, 1998). 
Nessa premissa, que são os fundamentos da sucessão ecológica, por meio de pesquisas e iniciativas de restauração, muito tem se buscado otimizar a restauração através da própria capacidade do meio ambiente em se regenerar, tendo como base os processos ecológicos que ocorrem na regeneração natural.

Essa nova frente de estudos e procedimentos de restauração florestal, baseada nos aspectos da regeneração natural, vem ao encontro das questões de qualidade da restauração, bem como de sua aplicabilidade, tendo em vista que a restauração de áreas através do processo convencional de reflorestamento apresenta alto custo e, em muitos casos, baixa eficiência no estabelecimento das mudas, o que dificulta a aceitação por parte dos produtores rurais.

Outro aspecto a ser considerado é que a restauração florestal através da regeneração natural apresenta um custo por área significativamente inferior quando comparado aos reflorestamentos que contemplam o plantio de mudas, o que é interessante para o Espírito Santo, onde aproximadamente $80 \%$ dos imóveis rurais são ocupados por agricultores familiares que, em sua grande maioria, não possuem condições econômicas de restaurar áreas por meio das técnicas de plantio. Dessa forma, o processo de regeneração natural para a restauração florestal é a forma mais ecológica, econômica e de fácil aceitação pelos produtores rurais.

Com isso, e diante dos desafios de se ampliar a cobertura florestal e atender à Legislação Florestal, faz-se necessário identificar a capacidade que as diferentes regiões do Espírito Santo têm de formarem uma cobertura florestal por meio dos processos de regeneração natural, bem como de prover os técnicos de uma ferramenta para o diagnóstico local da viabilidade de ocorrência de regeneração natural de floresta em determinada área. 


\section{2 \\ Revisão de literatura}

Segundo Gama et al. (2002), a regeneração natural decorre da interação de processos naturais de restabelecimento do ecossistema florestal. É, portanto, parte do ciclo de crescimento da floresta e refere-se às fases iniciais de seu estabelecimento e desenvolvimento. 0 estudo da regeneração natural permite a realização de previsões sobre o comportamento e o desenvolvimento futuro da floresta, pois fornece a relação e a quantidade de espécies que constituem seu estoque, bem como suas dimensões e sua distribuição na área (CARVALHO, 1982).

O termo regeneração natural representa um parâmetro fitossociológico, logo ele é calculado, e não medido ou contado, e representa também a estrutura da regeneração natural, pois é um parâmetro que expressa a densidade (abundância relativa), a distribuição espacial (frequência relativa) e a estratificação (categoria de tamanho relativa) dos indivíduos de uma espécie ou da floresta, isto é, da regeneração natural, sendo seu valor dado pela média aritmética desses três parâmetros. Densidade, frequência, dominância, índice de valor de importância, classe absoluta e relativa de tamanho da regeneração natural e valor de importância ampliado para a regeneração natural também podem ser avaliados considerando o descrito por Curtis e McIntosh (1951) e por Finol (1971).

É importante destacar também que o termo regeneração natural pode ser interpretado como um dos extratos da floresta, formado pelo banco de plântulas e indivíduos jovens, e também como o processo em que as florestas se regeneram após distúrbios, como a regeneração em clareiras, em campos de cultivo abandonados e outros.

Na restauração florestal através da regeneração natural, não são usadas técnicas de plantio ou outras intervenções silviculturais, sendo este o meio mais econômico de restauração, pois estão ausentes os custos 
com a produção e/ou compra de mudas, mão de obra, insumos e manutenção do plantio. Para Magnago et al. (2012), a regeneração natural é ferramenta importante para a restauração florestal, principalmente para grandes áreas geográficas, onde os métodos de plantio e outros podem ser inviáveis devido aos elevados custos financeiros.

Para que a regeneração natural ocorra, é necessário que se inicie o processo de sucessão, caracterizado pela sequência de comunidades vegetais, animais e micro-organismos que sucessivamente vão ocupando uma área ao longo do tempo (KIMMINS; MAILLY, 1996). Para isso, os componentes naturais que atuam na sucessão e que respondem às perturbações do meio, como as fontes de propágulos, os agentes de dispersão, as condições microclimáticas e o substrato para o estabelecimento dos ingressos vegetativos, devem estar presentes e atuando (CAMPELLO, 1998).

Destaca-se, nesse sentido, a alta capacidade de reação da natureza às mais diversas alterações na vegetação, principalmente em regiões tropicais, uma vez que água e temperatura não são fatores limitantes (NEPSTAD et al., 1991), sendo demonstrada por Vieira e Scariot (2006) e Sampaio et al. (2007) a importância da regeneração natural na restauração de floresta estacional decidual. Contudo, em locais onde ocorre a degradação do solo, a ausência de matéria orgânica faz com que essas florestas apresentem baixa resiliência, ou seja, a reação ambiental para retorno às condições anteriores pode não ocorrer, ou ser muito lenta (CARPANEZZI et al., 1990).

Durigan e Engel (2012) relatam que, em muitas circunstâncias, pode-se contar com a resiliência do ecossistema e a restauração se fará naturalmente. Já Magnago et al. (2012) afirma que áreas degradadas podem vir a se recuperar naturalmente por meio de processos sucessionais, desde que a matriz onde estejam inseridas seja permeável à fauna e contenha fragmentos fornecedores de propágulos. Neste sentido, a restauração florestal pode ser com baixa diversidade ou depender apenas da regeneração natural quando a matriz da paisagem é florestal, uma vez que o enriquecimento com espécies nativas no decorrer do tempo tende a ser natural (MARTINS et al., 2012).

Rodrigues e Gandolfi (2004) e Martins (2013) abordam que isolar determinada área degradada dos fatores de perturbação é o primeiro procedimento a ser adotado na sua restauração. Os autores afirmam que o cercamento da área impede o acesso de animais (equinos, bovinos e caprinos etc.) e limita espacialmente a atividade agrícola, permitindo que os processos ecológicos se restabeleçam e promovam a regeneração natural das espécies. Nessa diretriz, e considerando uma paisagem favorável, muitas vezes basta remover os agentes degradantes e proteger as 
áreas para estimular a sucessão (FERRETTI, 2002; JESUS; ROLIM, 2005; MARTINS, 2007; 2013).

Como exemplo do que se refere ao potencial da regeneração natural como estratégia de restauração florestal, estudos desenvolvidos por Almeida Junior (2006) demonstram que, em 1970, as florestas em estágio médio/avançado e em estágio inicial de regeneração cobriam, respectivamente, $14,51 \%$ e 5,62\% da área do município de Santa Maria de Jetibá - ES, ao passo que, em 2005, as florestas em estágio médio apresentavam cobertura de $34,55 \%$ e em estágios iniciais, $2,62 \%$, o que deixa claro o sucesso da regeneração natural na recomposição da paisagem florestal do município.

Para promover o sucesso da regeneração natural, algumas premissas devem ser atendidas. Os fatores que influenciam diretamente os processos sucessionais de uma área são citados por Magnago et al. (2012), Martins (2009), Martins et al. (2012) e por Campello (1998): oferta de propágulos e banco de sementes; histórico de uso da área; presença de dispersores; exposição do relevo, condicionamento do substrato e presença de espécies-problema.

A oferta de propágulos pode ser considerada fator limitante para a regeneração de determinadas áreas (HOLL, 1999; CLARK; POULSEN, 2001). A distância da área a ser restaurada em relação a fragmentos florestais fornecedores de propágulos é estratégica para o sucesso da regeneração natural. A razão para isso é a importância dos fragmentos de vegetação florestal nativa como fornecedores de propágulos que permitem a recolonização vegetal (CAMPELLO, 1998).

A maioria das espécies se dispersa por via anemocórica ou zoocórica; portanto, a distância da fonte de propágulos influencia diretamente a quantidade dematerialvegetativo que chega sobre osolo(McCLANAHAN, 1986; SILVA et al., 1996). Estudos desenvolvidos por Kolb (1993) e Parrota (1993) mostram a existência de uma correlação negativa entre o fluxo de ingressos vegetativos e o aumento na distância das vegetações que abastecem o local, considerando que os agentes dispersores migram entre fragmentos florestais e que precisam se abrigar ou descansar durante esses trajetos.

Entretanto, o estado do banco de sementes do solo é forte indicativo da capacidade de resiliência de um ecossistema degradado ou dos estágios sucessionais de suas florestas (MAGNAGO et al., 2012). Através do banco de sementes do solo e outros propágulos, muitas espécies herbáceas e arbustivo-arbóreas conseguem permanecer no solo com capacidade de regeneração, ou seja, o potencial florístico inicial, representado por tecidos ou sementes em estado dormente no solo, pode ser suficiente para desencadear o processo sucessional (EGLER, 1954; MARTINS, 2009). 
O substrato onde os propágulos se estabeleceram para o início da regeneração natural é fator preponderante no sucesso da regeneração natural, pois há a necessidade de se ter condições mínimas de estrutura e fertilidade do solo para o desenvolvimento de uma cobertura vegetal (CAMPELLO, 1998). Segundo Magnago et al. (2012), em paisagens fragmentadas, intensamente cultivadas e com forte compactação do solo, dificilmente ocorrerá regeneração natural satisfatória, sendo necessário algum tipo de manejo que recupere as condições edáficas, associado à transferência de material alóctone.

Como componentes que influenciam os processos sucessionais e a regeneração natural estão os agentes dispersores. O papel dos dispersores de propágulos é fundamental tanto para o sucesso individual da planta quanto para a dinâmica das populações (VOLPATO et al., 2012).

De acordo com Campello (1998), os agentes dispersores podem ser divididos em abióticos e bióticos.

Entre os abióticos, estão as dispersões autocóricas (abertura do fruto e queda direta das sementes), hidrocórica (água), barocórica (queda do fruto); sendo que a dispersão anemocórica (vento) abrange maior número de espécies dentro do grupo, na maioria dos ambientes tropicais.

A via zoocórica compreende todos os agentes bióticos de dispersão. Morcegos, aves e pequenos roedores constituem alguns dos principais dispersores de espécies vegetais de hábitos de crescimento pioneiro, fundamentais no processo de sucessão vegetal. De maneira generalizada, a dispersão zoocórica tem maior influência em florestas tropicais, em razão da complexidade do ambiente e das relações coevolutivas (COSTA et al., 1992). Entretanto, com base nos resultados de alguns trabalhos, verifica-se também em termos gerais uma tendência de que, em ambientes degradados, ocorra uma prevalência da dispersão anemocórica nos estágios iniciais da sucessão.

Especificamente em se tratando da dispersão zoocórica por intermédio de aves, que incluem frutos em sua dieta, elas atuam na dispersão de sementes e são elementos relevantes nos processos de regeneração natural de paisagens degradadas (LOISELLE; BLAKE, 1991; GALINDOGONZÁLEZ et al., 2000; TABARELLI; PERES, 2002), sendo então agentes da aceleração dos processos de sucessão e recuperação da biodiversidade. Aves frugívoras frequentando áreas degradadas podem ser as principais responsáveis pela movimentação de propágulos de espécies pioneiras, o que contribui para o aumento da cobertura vegetal e o sombreamento do solo, permitindo que a regeneração natural aconteça por meio do estabelecimento de espécies secundárias e tardias (WUNDERLE, 1997; GUEVARA et al., 2004). 
O sucesso da regeneração natural, portanto, dependerá principalmente da capacidade dos propágulos de fontes florestais adjacentes de alcançarem a área em restauração, sendo a fauna dispersora de sementes apontada como o principal agente para que isso aconteça com sucesso (VOLPADO et al., 2012).

A exposição do relevo também é questão importante na determinação da velocidade da regeneração natural, pois áreas com declividade acentuada tendem a estar mais propícias a processos erosivos, atrasando ou inviabilizando a sucessão ecológica. Segundo Magnago et al. (2012), outro fator que está sujeito ao tipo de exposição do relevo refere-se à manutenção de umidade do solo. Áreas expostas ao sol da tarde tendem a manter menor umidade no solo e, por isso, dificultam o estabelecimento de indivíduos arbóreos, além de favorecer a propagação de gramíneas agressivas.

Finalizando os fatores que influenciam os processos sucessionais, tem-se a presença de espécies-problema, que são aquelas nativas ou exóticas que formam populações fora de seu sistema normal ou fora de seu tamanho desejável (MOREIRA; PIOVEZAN, 2005). Gramíneas invasoras (ex.: gramíneas africanas) podem impedir o processo de regeneração natural e as espécies nativas podem explodir em densidade ou biomassa (MAGNAGO et al., 2012). Um exemplo desse aspecto é o aumento de biomassa de espécies de lianas na borda de fragmentos florestais, que tem sido reportado por pesquisadores como um dos principais agentes que desaceleram os processos de avanços sucessionais nas florestas atlânticas.

Ecossistemas estáveis são resilientes a perturbações, sejam estas naturais ou resultantes da ação humana. Estimular ou conduzir a regeneração natural é um importante método de restaurar a vegetação nativa, devido ao custo reduzido e ao ganho em diversidade vegetal no local restaurado, pois permite que espécies de outras formas de vida que não somente a arbórea sejam incorporadas à área, aumentando a representatividade florística e genética das formações vegetais em restauração e com maior probabilidade de sucesso (RODRIGUES; GANDOLFI, 2004; MARTINS, 2013). 



\section{3 \\ Objetivos}

\subsection{Objetivo geral}

Levantar o potencial de regeneração natural nas diferentes regiões do Estado do Espírito Santo, visando contribuir no processo de aumento da cobertura florestal nativa de forma simples, eficiente, com baixo custo e maior aceitação pelos produtores rurais e outros componentes do setor florestal capixaba.

\subsection{Objetivos específicos}

- Fornecer dados e informações que servirão de base para a elaboração de estratégias de restauração florestal dos programas e ações de políticas públicas e privadas relativas ao tema.

- Subsidiar decisões relativas ao uso de tecnologias apropriadas para a restauração florestal, com foco na otimização dos recursos, funções ecológicas e redução dos custos da restauração.

- Fornecer uma ferramenta para a utilização no setor público e na iniciativa privada, visando à elaboração de propostas de restauração florestal por meio da regeneração natural, fazendo uso de um manual que contém uma matriz de enquadramento com as respectivas ações para a restauração.

- Diminuir as disparidades de cobertura florestal protegida encontrada nas diferentes regiões do Estado do Espírito Santo. 



\section{4 \\ Metodologia}

\subsection{Princípios gerais}

Para se alcançar o objetivo deste estudo, algumas etapas e atividades foram desenvolvidas, visando classificar as regiões do Estado do Espírito Santo quanto ao seu potencial de restauração florestal por meio da regeneração natural, indicando de forma regional sua capacidade em regenerar naturalmente uma vegetação florestal nativa. Os estudos desenvolvidos levaram também à elaboração de um manual de classificação e diagnóstico local do potencial de regeneração natural. A metodologia utilizada no estudo e todas as atividades estão descritas nos itens a seguir, considerando a ordem em que foram desenvolvidas.

\subsection{Determinação da dimensão amostral}

Para o estudo dos parâmetros florestais, foi necessário inicialmente determinar a dimensão amostral que representasse relevância estatística e confiabilidade da metodologia. Com isso, realizou-se um teste de aferição em vários locais representativos das diferentes macrorregiões do Estado, por meio do qual foi observado que o levantamento de $10 \%$ da área aferida proporcionou uma pequena variação (de aproximadamente 4,5\%) nos resultados dos parâmetros florestais avaliados. Portanto, concluiu-se que, ao se utilizarem $10 \%$ do total da área aferida, são obtidos dados confiáveis.

A área estudada (460.632,75 hectares), correspondente a 10\% da área total do Estado, foi estabelecida colocando-se uma malha sobre o mapa do Estado do Espírito Santo (Figura 1) e dividindo-o em 313 (trezentas e treze) unidades amostrais, distribuídas de forma equidistante, tendo uma área média por unidade em torno de 1.500 ha. O estabelecimento 
dessas unidades amostrais teve como referência a metodologia utilizada pela SOS Mata Atlântica em estudo realizado no Estado do Espírito Santo e em outros estudos e experiências de mapeamento florestal.

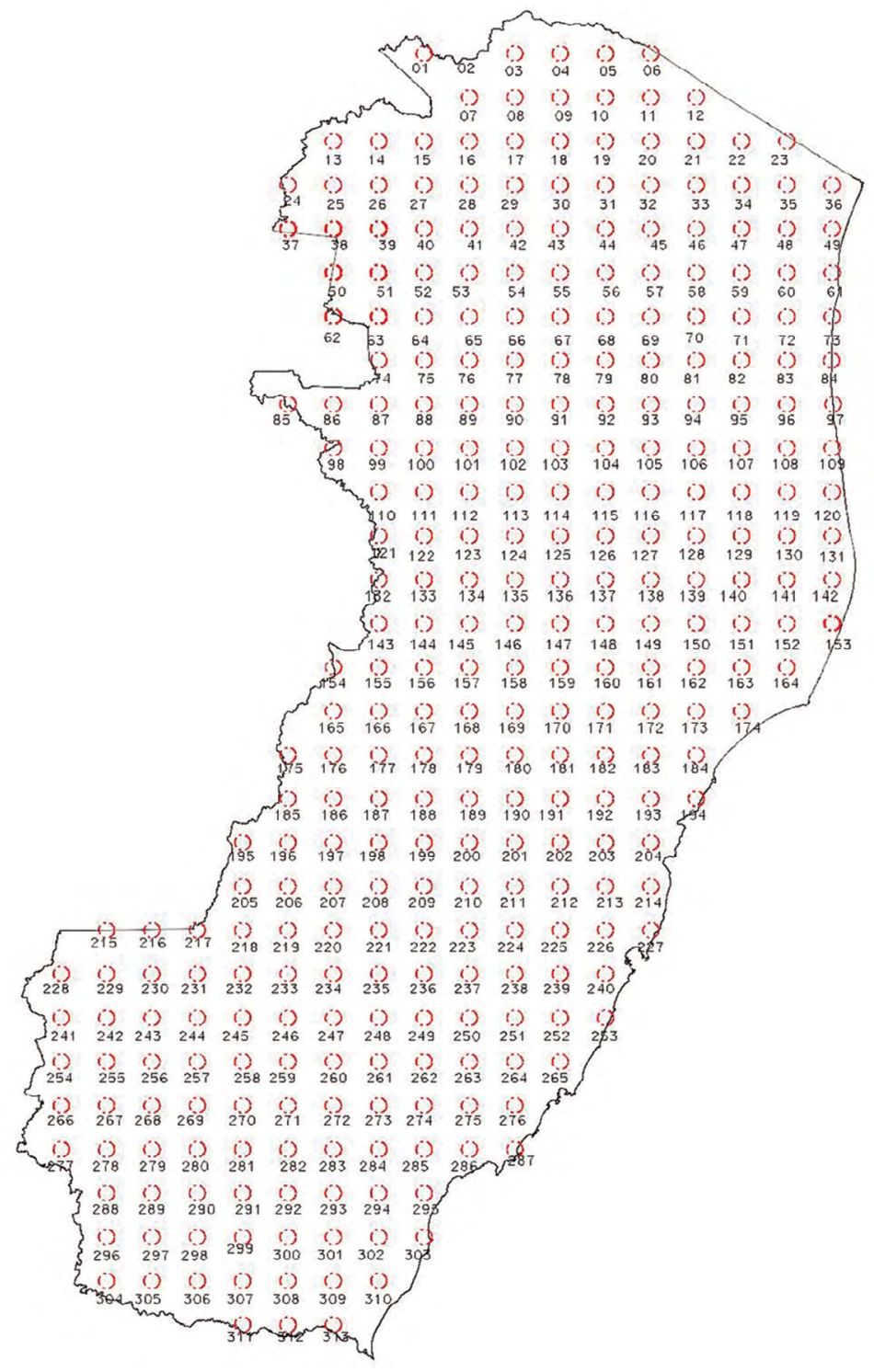

Figura 1 - Imagem da distribuição das unidades amostrais 


\subsection{Levantamento do número de fragmentos florestais regenerados}

Após o estabelecimento das amostras conforme demonstrado na etapa anterior, foi realizado o diagnóstico do número de fragmentos florestais regenerados, com área mínima de 1 (um) hectare, que se encontravam em estágio inicial de regeneração ou transição para estágio médio e os que se encontravam propriamente em estágio médio e avançado de regeneração.

Esses critérios foram estabelecidos considerando uma capacidade mínima de o fragmento florestal regenerado se perpetuar ao longo dos anos, possibilitado pela continuidade da sucessão ecológica, por isso o diagnóstico dos fragmentos regenerados considerou no mínimo aqueles que se encontravam em estágio inicial de regeneração ou transição para estágio médio.

A obtenção do número de fragmentos florestais regenerados foi realizada através da sobreposição de fotografias aéreas obtidas no ano de 1975 e fotografias aéreas obtidas no ano de 2007/2008. Por meio dessa sobreposição, foi possível diagnosticar o número de fragmentos florestais que se regeneraram considerando determinada unidade amostral sob estudo, ou seja, o diagnóstico foi feito quando na fotografia aérea obtida no ano de 1975, para determinada localidade, não havia fragmentos florestais, e na fotografia aérea do ano de 2007/2008, para a mesma localidade, existiam fragmentos florestais regenerados, conforme exemplificado na Figura 2.
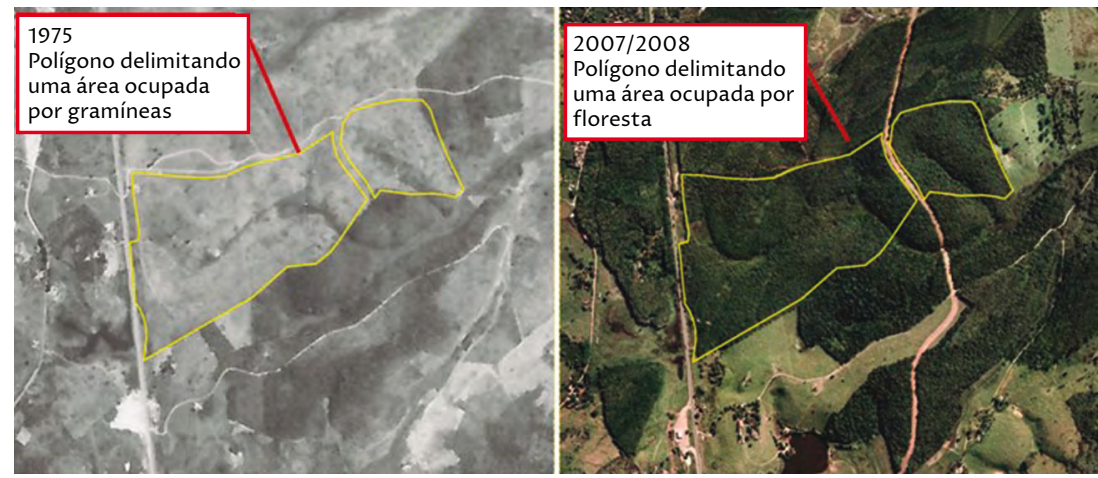

Figura 2 - Fotografias aéreas do ano de 1975 e de 2007/2008 demonstrando um fragmento florestal regenerado no Estado do Espírito Santo 
Após o diagnóstico do número de fragmentos florestais regenerados em cada unidade amostral, o valor obtido foi extrapolado para a área total do Espírito Santo, visando-se obter o número total/universo de fragmentos florestais regenerados e em processo de regeneração em todo o Estado. Esse universo foi a base para o cálculo amostral e também utilizado para a apresentação dos resultados no que se refere ao número de fragmentos florestais regenerados por zona.

\subsection{Cálculo estatístico amostral}

Após a obtenção do número de fragmentos florestais regenerados no Estado do Espírito Santo, foi realizado o cálculo estatístico amostral, com o objetivo de se obter o número de amostras/fragmentos florestais a serem estudados por meio da técnica de fotointerpretação e visitados em campo. Para o cálculo estatístico amostral, foram considerados $3 \%$ de margem de erro e nível de confiança de $90 \%$.

\subsection{Estudo dos fragmentos florestais através de técnicas de fotointerpretação}

Foi realizado o estudo em 700 fragmentos florestais regenerados, número obtido no cálculo amostral realizado na etapa anterior e tendo como base os 18.979 fragmentos florestais regenerados em todo o Espírito Santo, valor obtido no diagnóstico realizado na etapa 4.3. O critério para a distribuição do número de fragmentos florestais estudados em cada unidade amostral foi o da proporcionalidade, ou seja, nas unidades amostrais onde ocorreu maior quantidade de fragmentos florestais regenerados, maior número de fragmentos florestais foi estudado. Ressalta-se que em algumas unidades amostrais não foram constatados fragmentos florestais regenerados.

O estudo contemplou os seguintes parâmetros: diagnóstico do estágio de regeneração do fragmento florestal; distância entre um fragmento florestal regenerado e outro fragmento florestal matriz, com área acima de 3 (três) hectares e que apresentava relevância ecológica e um potencial de fornecer propágulos (principal parâmetro); bem como outros parâmetros florestais, como número de fragmentos florestais regenerados e fornecedores de propágulos por $\mathrm{km}^{2} /$ zona, tamanho médio dos fragmentos florestais regenerados e fornecedores de propágulos por zona e a área de fragmentos florestais regenerados e fornecedores de propágulos por zona (Figura 3). 


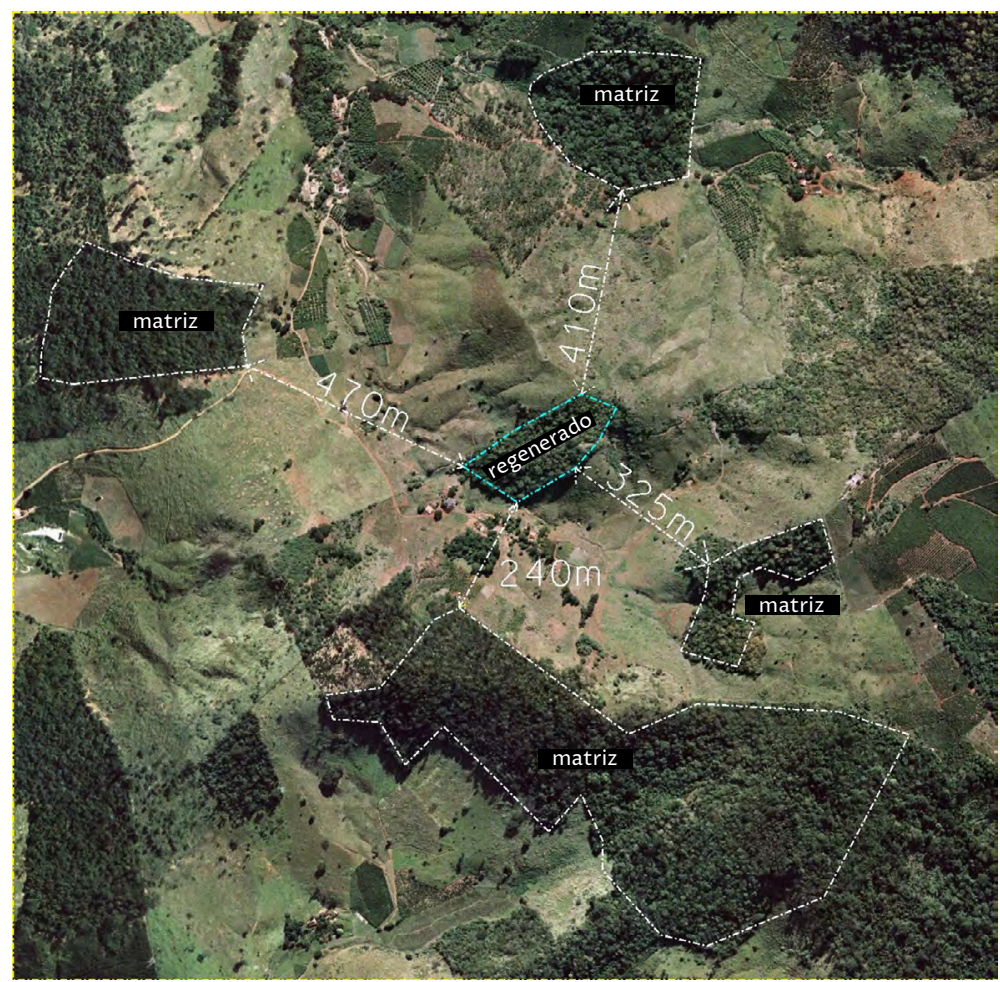

Figura 3 - Imagem de fragmentos florestais regenerados e fornecedores de propágulos demonstrando alguns parâmetros estudados

Outro estudo foi desenvolvido com o objetivo de se definir, em todas as zonas, o percentual de sua área, em relação à área total que tem potencial para receber propágulos em função de sua distância até determinado fragmento florestal de relevância ecológica e que seja um potencial fornecedor de propágulos. O percentual obtido foi o principal parâmetro utilizado para o enquadramento das zonas do Estado quanto ao seu potencial de regeneração natural.

Para este estudo, foi utilizado como base a média da distância entre os fragmentos florestais regenerados e os fragmentos florestais fornecedores de propágulos, considerando determinada zona. Os dados utilizados para o cálculo do valor médio foram aqueles que se encontravam dentro da curva-padrão de normalidade (maior frequência), tendo em vista o alto coeficiente de variação dos dados como um todo, como também a existência de diferenças nos fatores naturais dentro da mesma zona. Por isso, não foi utilizado o valor máximo de distância obtido entre 
o fragmento matriz (fornecedor de propágulos) e o fragmento regenerado (receptor de propágulos), e sim o valor médio das distâncias mais frequentes.

A partir desse valor médio, foi demarcado, em cada unidade amostral inserida em cada zona, um raio a partir da bordadura de todos os fragmentos florestais com área acima de 3 (três) hectares que apresentassem relevância ecológica e que fossem potenciais fornecedores de propágulos, delimitando uma área que representa a área potencial de receber propágulos.

Exemplificando: no cálculo dos valores médios de distância entre os fragmentos florestais potenciais fornecedores de propágulos e os fragmentos regenerados de determinada zona, foi obtido o valor de 500 metros. Em uma unidade amostral inserida nessa zona, foi demarcado um raio de 500 metros no entorno e a partir da bordadura em todos os fragmentos florestais matrizes. O computo da área na unidade amostral que foi abrangida pelo raio de 500 metros representou $66 \%$ da área total da unidade amostral, ou seja, considerando-se o fator distância de fonte de propágulo, que influencia diretamente os processos de regeneração natural, $66 \%$ da área total da unidade apresenta potencial para receber propágulos, conforme demonstrado na Figura 4. O percentual obtido foi utilizado na etapa 4.9 como critério para o enquadramento das zonas quanto ao seu potencial de regeneração natural.

\subsection{Zoneamento para regeneração florestal natural do estado do Espírito Santo}

Foi realizado um zoneamento do Estado do Espírito Santo de acordo com suas características pedológicas, topográficas, climáticas e de cobertura florestal de origem nativa, objetivando agrupar as diferentes áreas territoriais conforme suas semelhanças. Os mapas de unidades naturais, de precipitação, cobertura florestal e de pedologia foram utilizados como ferramenta para o zoneamento do Estado do Espírito Santo (Figura 5). 


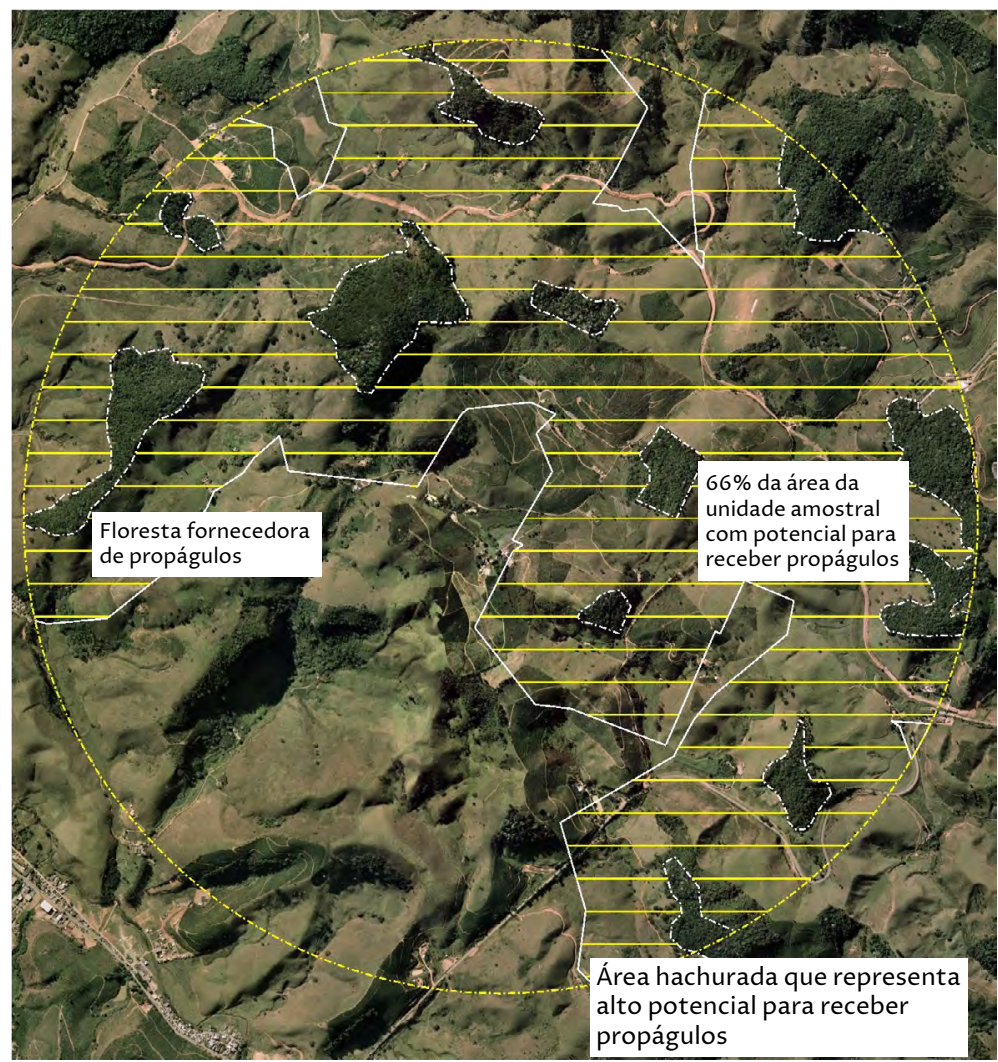

Figura 4 - Fotografia aérea de uma unidade amostral demonstrando o seu potencial para receber propágulos

O objetivo desse zoneamento foi possibilitar a classificação do potencial de regeneração natural de acordo com a similaridade entre os fatores pedoclimáticos e de cobertura florestal. Na Figura 6, está demonstrado o zoneamento realizado visando à classificação do potencial de regeneração natural, tendo como critério de agregação de áreas a metodologia descrita. A nomenclatura dada para as zonas foi a utilizada para a apresentação dos resultados. 

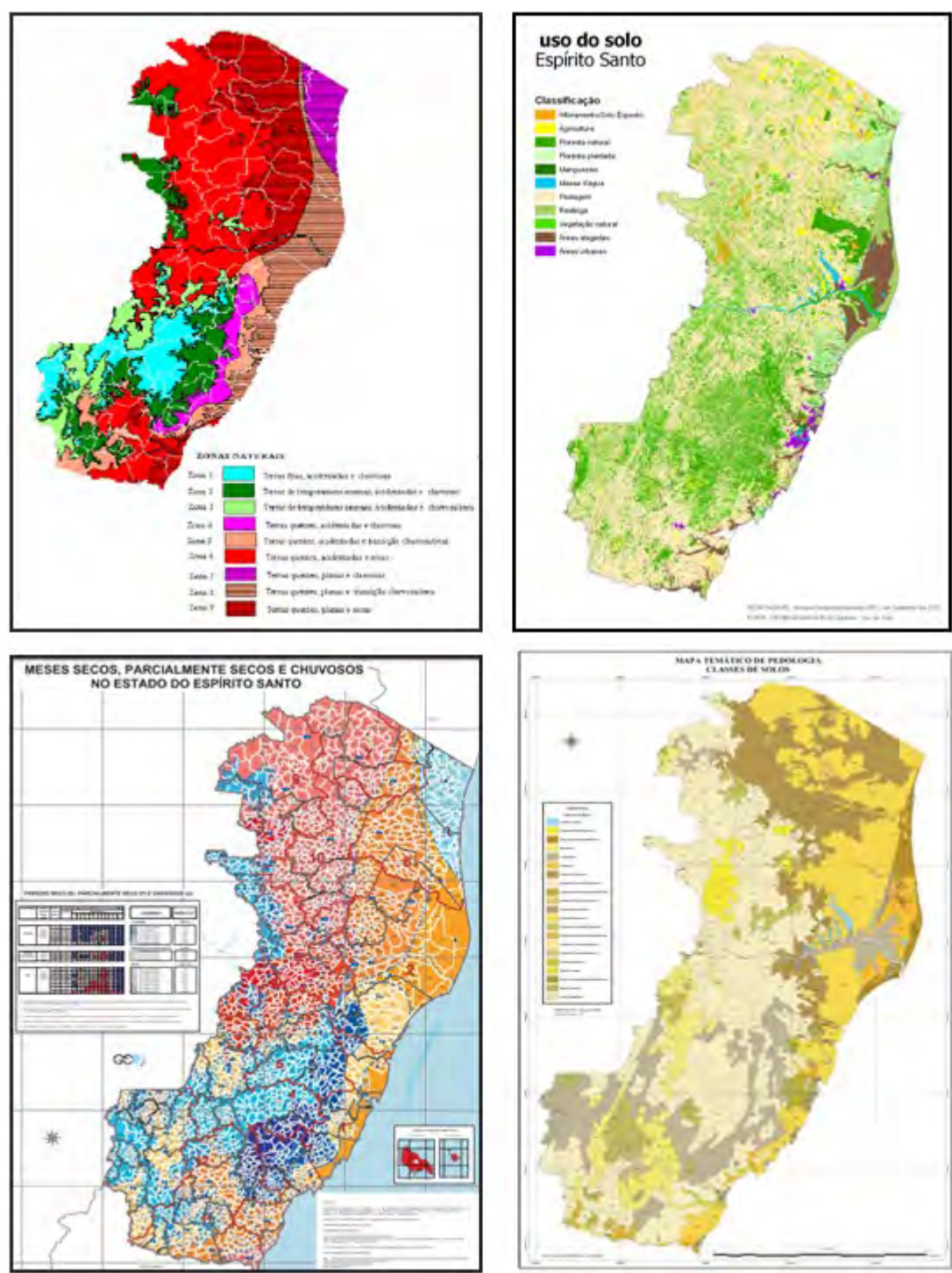

Figura 5 - Mapas de unidades naturais, precipitação, cobertura florestal e de pedologia do Estado do Espírito Santo utilizados para o zoneamento 


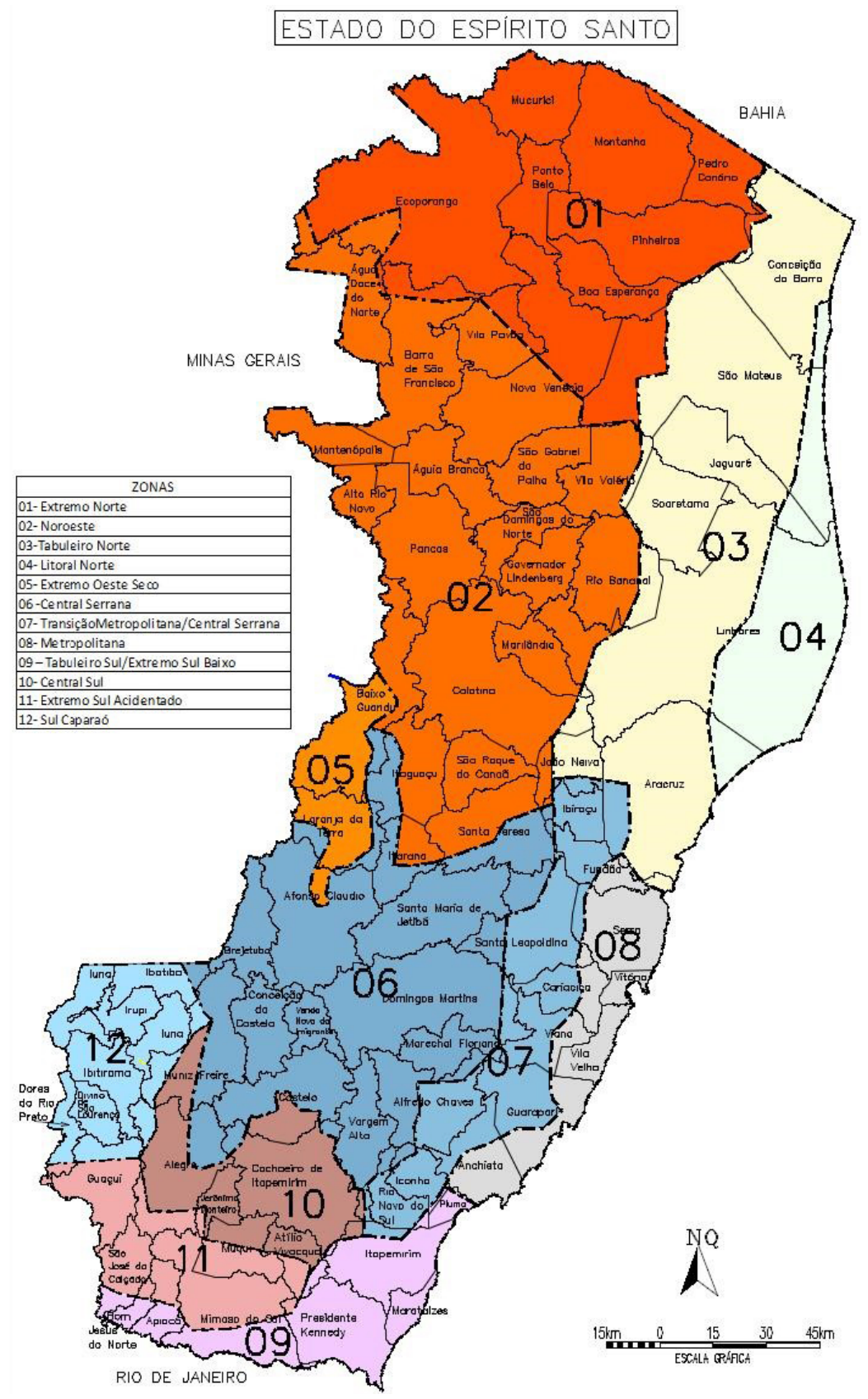

Figura 6 - Zoneamento do estado considerado para a classificação do potencial de regeneração natural 
Características físicas das Zonas de Regeneração

- Zona Extremo Norte - Caracteriza-se por possuir baixíssima cobertura florestal natural, com fragmentos matrizes (fornecedores de propágulos) de baixa densidade e muito isolados. Possui predominantemente relevo plano a ondulado (abaixo de $20 \%$ de declividade), denominado "tabuleiro", e solos com baixa fertilidade natural. Apresenta clima quente, com precipitação anual em torno de $1.050 \mathrm{~mm}$ e 6,5 meses secos, concentrados no outono e no inverno.

- Zona Noroeste-Apesar de possuir baixa cobertura florestal natural, apresenta grande número de fragmentos florestais matrizes, dispersos na maior parte da área, com pequena distância entre eles, que servem como fonte de propágulos. Possui predominantemente relevo acidentado e solos com baixa fertilidade natural, havendo grandes manchas, com solos de alta fertilidade, nas margens do Rio Doce e em locais próximos. Apresenta clima quente, com precipitação anual em torno de $1.150 \mathrm{~mm}$ e de 6,5 a 7 meses secos, concentrados no outono e no inverno. Há também nessa zona, na divisa com Minas Gerais, áreas mais altas, com clima ameno, mais chuvoso e com menor deficiência hídrica.

- Zona Tabuleiro Norte - Caracteriza-se por possuir baixa cobertura florestal natural, dispersa na maior parte da área, porém apresenta também grandes florestas concentradas em unidades de conservação, a exemplo da Reserva Natural Vale e da Reserva Biológica de Sooretama, e nas áreas da empresa Fibria, localizadas nos municípios de São Mateus, Conceição da Barra e Aracruz, que servem de fonte de propágulos para as áreas mais próximas. Possui predominantemente relevo plano a ondulado (abaixo de 20\% de declividade), denominado "tabuleiro", e solos com baixa fertilidade natural. Apresenta clima quente, com precipitação anual em torno de $1.200 \mathrm{~mm}$ e de 4,5 a 6 meses secos, concentrados no outono e no inverno. Nessa zona, particularmente na Reserva Vale, ocorrem transições abruptas entre a floresta primária e manchas de vegetação campestre chamadas de "nativos" ou arbustivo-arbóreas, fitofisionomias denominadas "mussunungas". Essas manchas de vegetação campestre caracterizam o clímax edáfico, no qual o solo arenoso e com camada de laterita em pequenas profundidades dificulta a drenagem na estação chuvosa. Como áreas pequenas de campo nativo isoladas na matriz florestal, apresentam alto valor de conservação na condição campestre. 
- Zona Litoral Norte - Caracteriza-se por possuir relevo plano a suave ondulado, solos arenosos (Neossolo Quartzarênico), com vegetação natural de "Restinga", principalmente ao longo do litoral, e solos orgânicos encharcados, com vegetação natural predominantemente herbácea, os quais apresentam acidez elevada e alta limitação de uso econômico. Também ocorrem os solos aluviais, em sua maioria de alta fertilidade, em especial ao longo do Rio Doce, com florestas primárias sombreando a cultura do cacau, sistema denominado "cabruca". Tal como ocorre na zona Tabuleiro Norte, nessa zona existem algumas manchas de áreas arenosas, com lençol freático alto, em função da existência de camadas endurecidas (laterita), em pequenas profundidades, com predominância de capim-navalha, também chamadas de "mussunungas". Apresenta clima quente, com precipitação anual em torno de $1.300 \mathrm{~mm}$ e 5 meses secos, concentrados no outono e no inverno.

- Zona Extremo Oeste Seco - Apresenta razoável cobertura florestal e grande número de fragmentos florestais matrizes dispersos na maior parte da paisagem, com pequena distância entre eles, que servem como fonte de propágulos. Possui predominantemente relevo acidentado e solos com alta fertilidade natural. Apresenta clima quente, com precipitação anual em torno de $900 \mathrm{~mm}$ e 8 meses secos, concentrados no outono e no inverno. Caracteriza-se também pela predominância da espécie Myracrodrum urundeuva (aroeira-do-sertão) nos fragmentos regenerados.

- Zona Central Serrana - Caracteriza-se por possuir elevada cobertura florestal, na maior parte de sua área, com fragmentos matrizes em pequenas distâncias entre eles, que servem como fonte de propágulos. Possui predominantemente relevo acidentado e solos com baixa fertilidade natural, havendo algumas inclusões (manchas) com solos de alta fertilidade e outras com solos muito ácidos e arenosos em relevos declivosos em que há dificuldade de crescimento de vegetação arbórea e domínio de samambaia (Pteridium aquilinum). Apresenta clima frio, ameno e chuvoso, com precipitação anual variando entre $1.200 \mathrm{~mm}$ e 1.900 mm e de 1 a 3 meses de período seco, concentrados no inverno.

- Zona Transição Metropolitana/Central Serrana - Caracteriza-se por possuir alta cobertura florestal, na maior parte da área, com pequenas distâncias entre os fragmentos florestais, que servem como fonte de propágulos. Possui predominantemente relevo acidentado e solos com baixa fertilidade natural, havendo também manchas com solos de média a alta fertilidade em áreas 
pedregosas. Apresenta clima quente, com precipitação anual em torno de $1.500 \mathrm{~mm}$ e entre 2 e 3 meses de período seco, concentrados no inverno.

- Zona Metropolitana - Compreende principalmente a região da Grande Vitória e expansão para o Sul, possuindo predominantemente relevo plano a suave ondulado, entremeado com montanhas de rochas graníticas, e solos com baixa fertilidade natural, na maior parte da área. Apresenta clima quente, com precipitação anual variando entre 1.150 e 1.350 mm e 5 meses de período seco, concentrados no outono e no inverno.

- Zona Tabuleiro Sul/Extremo Sul Baixo - Caracteriza-se por possuir baixa cobertura florestal natural, com baixa densidade de fragmentos matrizes (fornecedores de propágulos), na maior parte da área. Possui predominantemente relevo suave e ondulado próximo ao litoral (platôs litorâneos) e acidentado em parte do extremo sul, com solos de baixa fertilidade natural. Apresenta clima quente, com precipitação anual variando entre 1.000 e 1.200 mm e 6 meses de período seco, concentrados no outono e no inverno.

- Zona Central Sul - Apresenta baixa cobertura florestal natural com fragmentos dispersos na maior parte da área. Possui predominantemente relevo acidentado com baixadas no fundo dos vales e predominância de solos com alta fertilidade natural. Apresenta clima quente, com precipitação anual de 1.050 a 1.350 mm e de 5 a 6 meses secos, concentrados no outono e no inverno.

- Zona Extremo Sul Acidentado - Possui uma cobertura florestal natural razoável, dispersa na maior parte da área, composta de pequenos fragmentos com pequenas distâncias entre eles, que servem como fonte de propágulos. Possui predominantemente relevo acidentado e solos com baixa fertilidade natural. Apresenta clima frio e ameno, com precipitação anual variando entre 1.400 e $1.500 \mathrm{~mm}$ e 3 meses de período seco, na maior parte da área, concentrados no outono e no inverno.

- Zona Sul Caparaó - Apesar de possuir a unidade de conservação Parque Nacional do Caparaó, apresenta na maior parte da área baixa cobertura florestal. Possui predominantemente relevo acidentado e solos com baixa fertilidade natural. Apresenta clima frio e ameno, com precipitação anual variando entre 1.300 e $1.600 \mathrm{~mm}$ e de 3 a 4 meses de período seco, concentrados no outono e no inverno. Relatos antigos de Augusto Ruschi indicam a ocorrência natural de Araucaria angustifolia nessa zona, no Parque Nacional do Caparaó. 


\subsection{Levantamento de dados em campo}

Os estudos de campo foram realizados em $10 \%$ dos fragmentos florestais regenerados (ou seja, 70 fragmentos florestais) e estudados por meio da fotointerpretação. $O$ objetivo deste estudo foi confirmar as tipologias florestais desses fragmentos florestais regenerados identificados por meio da fotointerpretação, visando proceder a ajustes caso houvesse incoerências entre o diagnóstico da fotointerpretação e o diagnóstico em campo, principalmente quanto ao estágio de regeneração. $O$ estágio de regeneração das florestas foi determinado considerando os critérios estabelecidos na Lei Estadual n 5.361, de 30 de dezembro de 1996. Além disso, foram levantadas as principais espécies arbóreas de ocorrência nos fragmentos florestais regenerados para posteriores cálculos de parâmetros botânicos, tempo da regeneração natural e histórico de uso da área anterior ao início da sucessão secundária.

Os produtores rurais selecionados foram entrevistados para obtenção de informações sobre o tempo em que a área ocupada pelo fragmento florestal está se regenerando, considerando que o início da regeneração se deu após o ano de 1975, e também o histórico de uso da área antes e depois de se iniciar o processo de regeneração natural.

O objetivo principal dessas entrevistas foi identificar a velocidade da regeneração natural da floresta, o tipo de uso e o tempo em que a área era manejada antes de se iniciar a regeneração, como também se houve alguma interferência (fogo, gado, entre outros) durante o processo de regeneração.

No primeiro parâmetro, a velocidade da regeneração natural possibilitou identificar o tempo decorrido entre o abandono da área e os dias atuais, o que foi correlacionado com a tipologia florestal atual da floresta regenerada. No segundo parâmetro, buscou-se obter o histórico da área antes do início do processo de regeneração natural com o objetivo de se inferir se o processo ocorreu através de banco de sementes e outros propágulos no solo, ou se por aporte de propágulos provenientes de outros fragmentos florestais (chuva de sementes), considerando que um dos critérios utilizados nesse estudo para enquadramento das áreas quanto ao potencial de regeneração incluiu a distância de fontes de propágulos, bem como que foi definido nesse estudo que áreas com histórico de mais de 20 anos de manejo intensivo de solo, como arações, gradagem, uso do fogo, aplicação de herbicidas, entre outras práticas, não apresentam banco de sementes com viabilidade. 


\subsection{Análises estatísticas}

Os dados obtidos nas atividades descritas nos itens 4.3 e 4.5 foram tabulados e foram feitas análises estatísticas para inferências quanto a correlações entre os parâmetros, desvio-padrão e coeficiente de variação dos dados, média dos dados de cada parâmetro diagnosticado, percentuais e distribuição normal.

Podem ser citados como exemplos os seguintes parâmetros avaliados estatisticamente: distância média entre os fragmentos florestais regenerados e os fragmentos florestais fornecedores de propágulos em cada zona; dimensão média de cada fragmento florestal regenerado em cada zona; correlação entre número de fragmentos florestais regenerados e a distância média entre fragmentos; percentual da área da unidade amostral, em relação a sua área total, com potencial para receber propágulos em função de sua distância de determinado fragmento florestal de relevância ecológica e coeficiente de variação dos dados dos parâmetros avaliados em cada zona.

\subsection{Classificação das zonas do Espírito Santo de acordo com o potencial de regeneração natural}

A classificação das zonas do Espírito Santo de acordo com o potencial de regeneração natural foi feita em função dos resultados de todas as atividades realizadas e discriminadas anteriormente, que auxiliaram também na definição dos pesos e pontuações dos indicadores utilizados para gerar a tabela diagnóstica para o enquadramento.

Os indicadores utilizados para essa classificação foram: percentual da área total de uma zona natural que tem potencial para receber propágulos vegetativos; precipitação (número de meses secos) e restrições pedológicas, que incluem fertilidade e formações geológicas. Para cada indicador foi estabelecido um peso, em função de sua importância na regeneração natural, a partir de uma matriz metodológica adaptada de Bellotto et al. (2009).

Considerou-se de alta importância o indicador que pode comprometer a regeneração natural fazendo com que o processo não exista ou seja muito lento mesmo após vários anos em que a área foi isolada dos fatores de degradação; de média importância o indicador que pode comprometer a regeneração natural dificultando os processos sucessionais; e de baixa importância o indicador que compromete em menor grau o processo de regeneração natural. 
O percentual da área total de uma zona natural que tem potencial para receber propágulos foi considerado de alta importância e recebeu peso 3, pois a ausência de fontes de propágulos necessários para colonizar uma área objeto de restauração através de regeneração natural impossibilita o estabelecimento e o desenvolvimento da vegetação.

Os outros parâmetros (precipitação e pedologia) constituíram-se como fatores restritivos, mas não impeditivos, no processo de regeneração na grande maioria das áreas das zonas.

Quanto aos solos (pedologia), existem alguns casos extremos, de parte de algumas zonas, que se constituem como fatores impeditivos à regeneração natural de floresta por possuírem manchas de solos permanentemente alagadas, áreas muito arenosas, compactadas naturalmente, de elevada acidez e baixíssima fertilidade, bem como afloramentos rochosos com elevada declividade. Podem ser citadas como casos extremos as áreas alagadas da zona Litoral Norte, com predominância de vegetação herbácea; e pequenas manchas dispersas na zona Central Serrana, com predominância de samambaia.

A baixa fertilidade predominante na maior parte do Estado, classificada sob o ponto de vista agronômico, não se mostrou, na maioria das zonas, como fator limitante que determinasse o processo de regeneração natural, porque existem as espécies florestais que se adaptam a essas condições, que não são extremas, tendo assim esse indicador obtido peso 1.

Já a precipitação, apesar de não ser fator impeditivo, por não existirem no Espírito Santo extremos hídricos, como clima desértico, teve influência relevante no processo de regeneração, especialmente na velocidade de formação do fragmento regenerado. Assim, o número de meses secos recebeu peso 2, pois há uma forte correlação entre a distribuição de chuva e a velocidade de regeneração natural.

Na Tabela 1, encontram-se descritos os indicadores avaliados, o grau de importância de cada um deles e o peso atribuído, tendo como base a metodologia descrita anteriormente.

Tabela 1 - Grau de importância dos parâmetros avaliados e respectivos pesos

\begin{tabular}{|c|c|c|}
\hline Grau de importância & Indicador & Peso \\
\hline Alto & $\begin{array}{c}\text { Percentual da área total de uma zona natural } \\
\text { que tem potencial para receber propágulos }\end{array}$ & 3 \\
\hline Médio & $\begin{array}{c}\text { Precipitação } \\
\text { (número de meses secos) }\end{array}$ & 2 \\
\hline Baixo & Restrições pedológicas & 1 \\
\hline
\end{tabular}


As pontuações para cada indicador foram estabelecidas por meio da adaptação do método de avaliação rápida de áreas restauradas (BRANCALION et al., 2012), seguindo um gradiente que varia de 0 a 3, sendo (0) nos casos em que o indicador está interferindo negativamente e com magnitude na regeneração natural; (1) para indicadores que estão interferindo negativamente e medianamente na regeneração natural; (2) para indicadores que estão interferindo com baixa magnitude na regeneração natural; e (3) para indicadores que não estão interferindo na regeneração natural (Tabela 2 ).

Tabela 2 - Critérios de pontuação para cada indicador avaliado

\begin{tabular}{|c|c|c|}
\hline \multicolumn{1}{|c|}{ Indicador } & Critério & Pontuação \\
\hline $\begin{array}{c}\text { Percentual da área total de uma zona natural } \\
\text { que tem potencial para receber propágulos }\end{array}$ & 0 a 35\% & 0 \\
\hline & acima de 35\% a 65\% & 1 \\
\hline & acima de 65\% a 75\% & 2 \\
\hline Precipitação & acima de 75\% a 100\% & 3 \\
\hline (número de meses secos) & 0 a 4 & 2 \\
\hline Restrições pedológicas & 4,5 a 6 & 1 \\
\hline & acima de 6 & 0 \\
\hline & alta restrição & 0 \\
\hline & média restrição & 1 \\
\hline
\end{tabular}

Assim, para cada área avaliada dentro do zoneamento preestabelecido, os indicadores foram pontuados e multiplicados pelo seu peso, em função do grau de importância. Com base na avaliação desses indicadores e na ponderação das notas obtidas pelo grau de importância, obteve-se uma tabela diagnóstica da zona estudada e uma nota final, conforme exemplificado hipoteticamente na Tabela 3, em que se trata de um caso de enquadramento do potencial de regeneração natural.

Essa nota final foi comparada à nota hipoteticamente obtida por uma área ideal quanto aos aspectos de potencial de regeneração natural, que alcançou nota máxima em todos os indicadores. No exemplo da Tabela 3, a zona natural obteve uma nota que representa $73,3 \%$ da nota de uma zona ideal. 
Tabela 3 - Tabela diagnóstica hipotética exemplificando um caso de enquadramento do potencial de regeneração natural de uma zona estudada, apresentando as notas obtidas em cada indicador

\begin{tabular}{|c|c|c|c|c|c|}
\hline Indicador & $\begin{array}{c}\text { Peso } \\
\text { (graude } \\
\text { importância) }\end{array}$ & $\begin{array}{c}\text { Nota } \\
\text { máxima do } \\
\text { indicador }\end{array}$ & $\begin{array}{c}\text { Nota } \\
\text { obtida do } \\
\text { indicador }\end{array}$ & $\begin{array}{c}\text { Nota } \\
\text { final } \\
\text { máxima }\end{array}$ & $\begin{array}{c}\text { Nota } \\
\text { final } \\
\text { obtida }\end{array}$ \\
\hline $\begin{array}{c}\text { Percentual da área total } \\
\text { de uma zona natural que } \\
\text { tem potencial para } \\
\text { receber propágulos }\end{array}$ & 3 & 3 & 2 & 9 & 6 \\
\hline \begin{tabular}{c} 
Número de meses secos \\
\hline $\begin{array}{c}\text { Restrições edáficas } \\
\text { (fertilidade eformação }\end{array}$
\end{tabular} & 2 & 2 & 2 & 4 & 4 \\
\hline \begin{tabular}{c} 
geológica) \\
\hline
\end{tabular} & 1 & 2 & 1 & 2 & 1 \\
\hline
\end{tabular}

A partir dessa comparação, foram estabelecidas quatro faixas de classificação, tendo como parâmetro de enquadramento o percentual da nota obtida pela zona estudada em relação à nota hipoteticamente obtida por uma área ideal, conforme a seguir: 0 a $35 \%$ da nota de uma zona ideal baixo potencial de regeneração natural; 35,1 a $65 \%$ da nota de uma zona ideal - médio potencial de regeneração natural; 65,1 a 75\% da nota de uma zona ideal - transição médio/alto potencial de regeneração natural; e 75,1 a $100 \%$ da nota de uma zona ideal - alto potencial de regeneração natural.

Critérios potenciais a serem utilizados no diagnóstico e enquadramento do potencial de regeneração natural, como topografia e exposição do relevo, não foram utilizados para o enquadramento, pois os estudos de campo mostraram que, em nível geográfico, ou seja, na escala de trabalho utilizada, esses fatores não são impeditivos ao processo de regeneração natural, por não estarem se manifestando de forma extrema. Em outras palavras, as áreas que apresentavam topografia acidentada e/ou face de exposição do relevo com alta radiação não impediram a regeneração natural, influenciando em outros fatores importantes, como velocidade de regeneração e tipo de espécies florestais.

\subsection{Síntese da metodologia}

A metodologia adotada neste trabalho seguiu algumas referências de autores consagrados no tema restauração florestal, adaptações de métodos já publicados, uma base sólida em termos estatísticos e também utilização aprofundada de técnicas de fotointerpretação, bem como foram idealizadas inovações metodológicas com o objetivo de se alcançar o resultado final. 
Com isso, consta na Figura 7 um fluxograma contendo as etapas que foram desenvolvidas na metodologia.

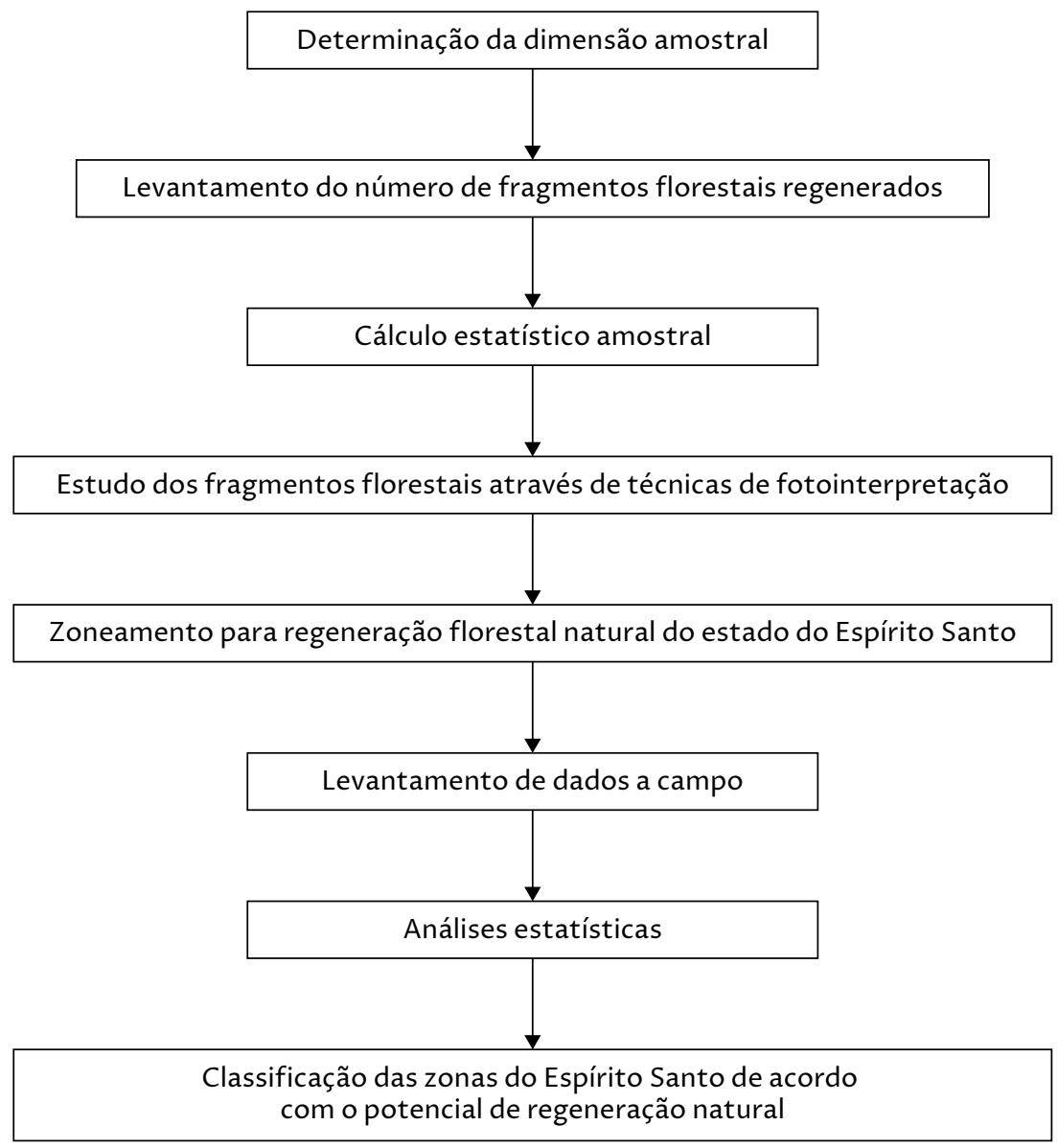

Figura 7 - Fluxograma síntese das atividades desenvolvidas 


\section{5}

\section{Resultados}

\subsection{Fatores que influenciaram a regeneração natural}

\subsubsection{Distância das florestas fornecedoras de propágulos (florestas matrizes)}

Esse parâmetro é fundamental para a existência de fragmentos regenerados, como também para a sua qualidade. Foi observado que em cada local existe uma distância mais frequente e máxima para que ocorra a regeneração natural. A proximidade das florestas fornecedoras de propágulos (florestas matrizes) com as áreas ocupadas por florestas regeneradas tem relação com a oferta de propágulos e foi um fator determinante para a regeneração natural.

Foi observado que a distância entre as florestas regeneradas e as florestas matrizes influenciou na velocidade da regeneração natural e na diversidade de espécies presentes nas florestas regeneradas, ou seja, quanto menor essa distância, mais rápida e de melhor qualidade ecológica foi a regeneração natural. Na Figura 8, está ilustrada uma floresta regenerada, que se encontrava anexa à floresta matriz e que alcançou o estágio médio de regeneração em apenas 15 anos. 


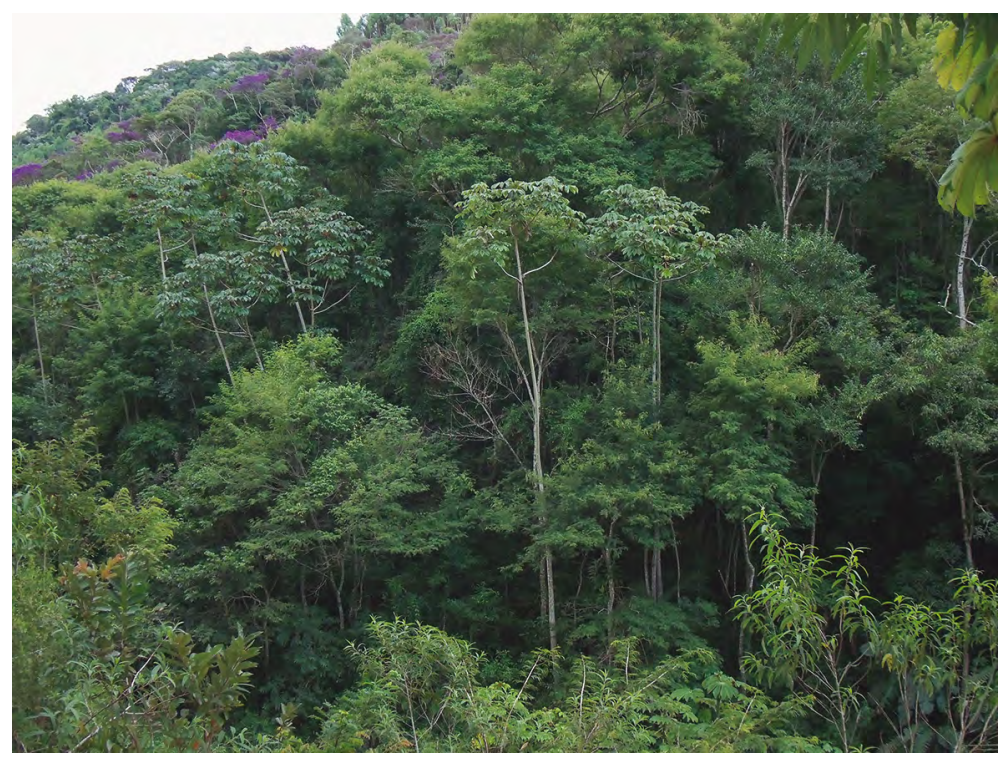

Figura 8 - Fragmento florestal localizado no município de Ibitirama-ES, em estágio médio de regeneração, anexo à floresta matriz e com 15 anos de regeneração

\subsubsection{Estrutura e funcionalidade das florestas matrizes}

A dimensão da floresta matriz e sua tipologia florestal (estágio de regeneração) foram fatores importantes na regeneração natural. Essas características têm correlação direta com a fauna dispersora, pois, quanto maior, mais diversificada e mais avançada for quanto ao estágio de regeneração natural a floresta matriz, mais biodiversa é a fauna presente nesses fragmentos, o que consequentemente possibilita a dispersão de propágulos de maior número de espécies florestais.

De forma geral, os fragmentos florestais regenerados apresentavam-se com maior diversidade e a velocidade de regeneração foi maior quando as florestas matrizes eram maiores e de melhor estrutura. Está ilustrada na Figura 9 uma floresta regenerada (lado esquerdo) ao lado da floresta matriz (lado direito) que ocupava uma área de 12 hectares e encontrava-se em estágio avançado de regeneração.

\subsubsection{Existência de bancos de sementes no solo}

Em algumas áreas, foi observado que a regeneração natural ocorreu através do banco de sementes, em função de serem áreas recém- 


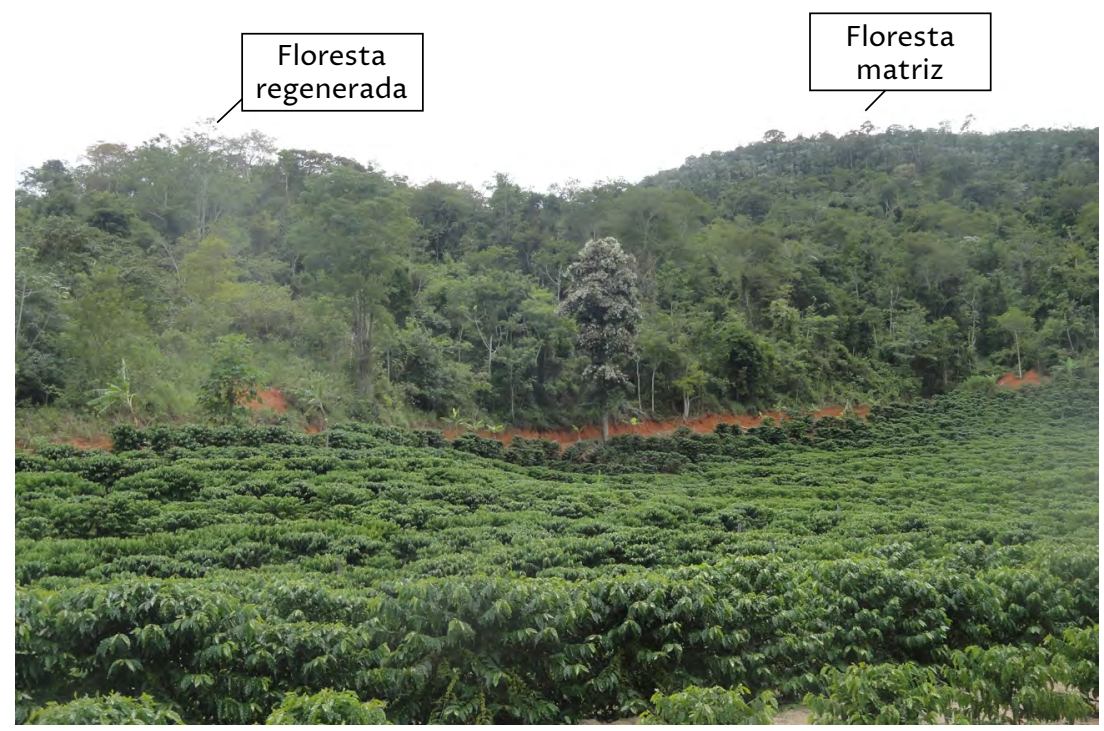

Figura 9 - Fragmento florestal, localizado no município de Nova Venécia-ES, em estágio médio de regeneração (lado esquerdo), ao lado da floresta matriz (lado direito)

-desmatadas. Um banco de sementes com viabilidade nas áreas a serem regeneradas é um grande indicativo do sucesso da regeneração natural (MARTINS, 2009).

Através do banco de sementes do solo e outros propágulos vegetativos, as espécies herbáceas e arbustivo-arbóreas se estabeleceram e o potencial florístico inicial representado por tecidos e sementes dormentes foi restaurado, originando florestas com estrutura e funcionalidade considerável, conforme ilustrado na Figura 10.

\subsubsection{Diferença de cota altimétrica entre a floresta matriz e a área regenerada}

Foi observado que, nas áreas ocupadas por florestas regeneradas que se encontravam em cota inferior à das florestas matrizes, a regeneração natural foi beneficiada pela facilidade da dispersão de propágulos, tanto por agentes bióticos dispersores quanto por agentes abióticos, como o vento (Figura 11).

Observou-se, de forma geral, que, nas áreas localizadas nessa condição topográfica, o aporte de propágulos foi facilitado, mesmo quando a floresta matriz estava mais distante. 


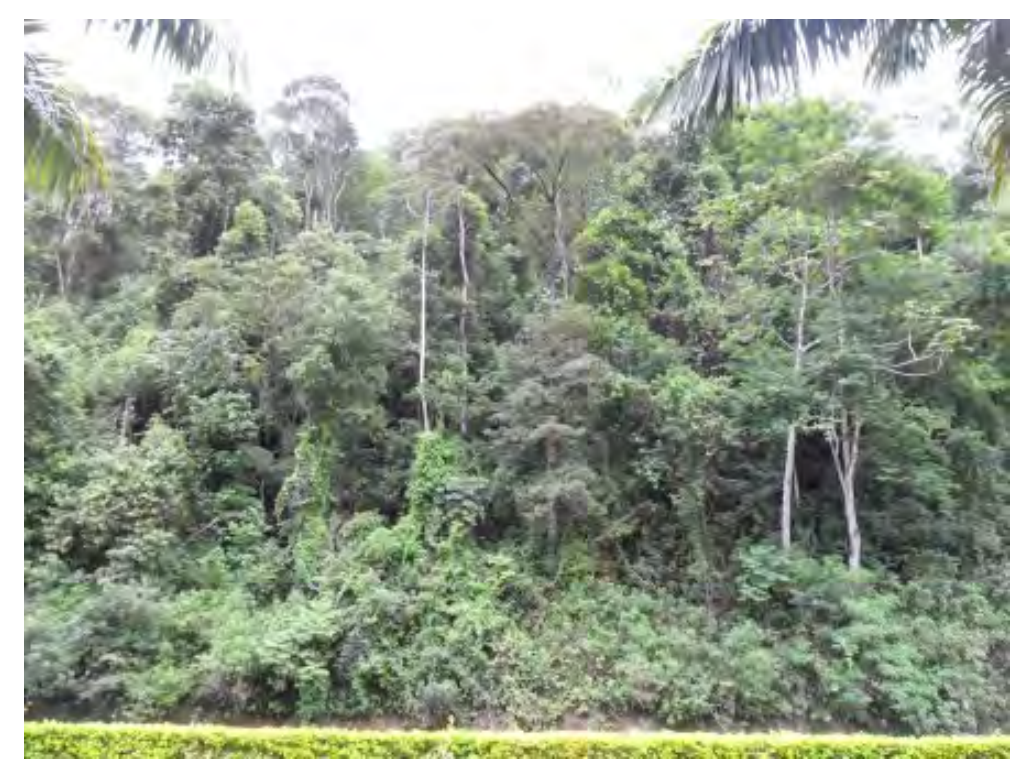

Figura 10 - Fragmento florestal localizado no município de Domingos Martins-ES, em estágio médio de regeneração, com 12 anos de regeneração principalmente através da existência de banco de sementes

Esta relação se explica pelos seguintes fatores: a) ação da gravidade importante para espécies com dispersão pela queda do fruto/semente (barocoria) ou pelo vento (anemocoria), em que a dispersão é favorecida das partes altas (cotas elevadas) para as baixadas; b) dispersão por animais (zoocoria) - nas baixadas geralmente se encontram os cursos-d'água, e os animais que residem nas florestas de topos de morro se deslocam até essas áreas para dessedentação, realizando a dispersão de sementes para elas.

\subsubsection{Forma do relevo}

As florestas regeneradas localizadas em relevo côncavo, por essas áreas serem importadoras de água e nutrientes, apresentavam-se com melhor estrutura que as florestas regeneradas localizadas em relevo convexo, que são exportadoras de água e nutrientes.

As grotas e baixadas geralmente são ambientes de solo mais fértil e com maior umidade, condições mais favoráveis à germinação e ao estabelecimento das sementes que chegam via dispersão das florestas matrizes.

Na Figura 12, pode-se observar um fragmento florestal onde a face côncava (lado esquerdo da foto) se apresenta com melhor estrutura e maior diversidade que a face convexa (lado direito da foto). 


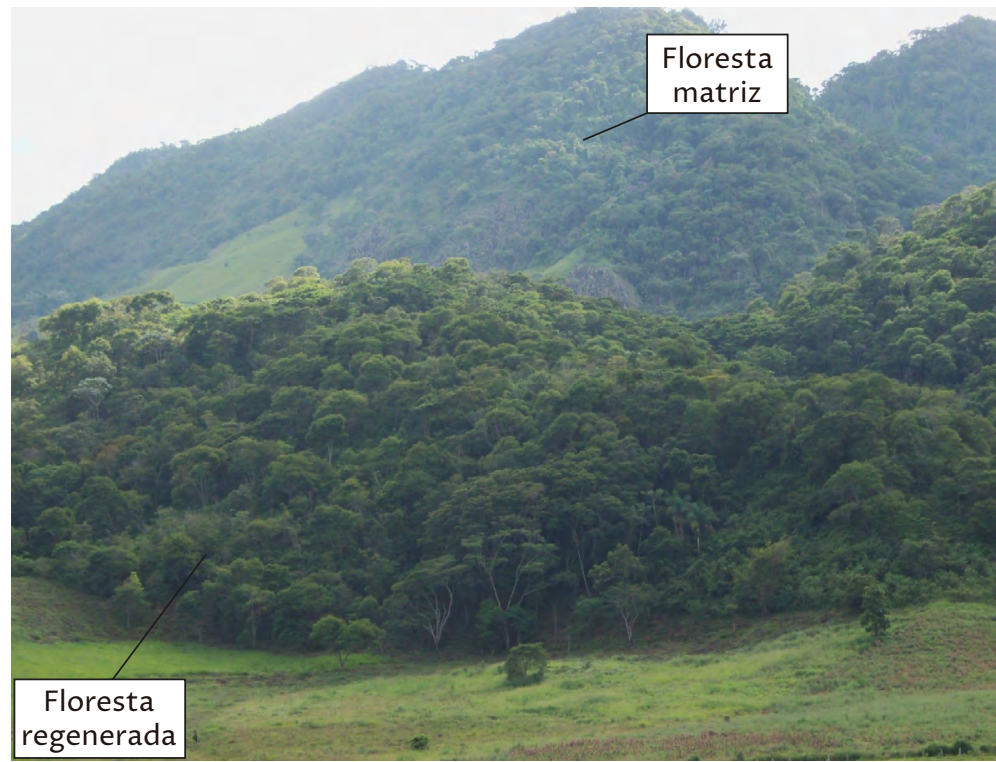

Figura 11 - Fragmento florestal em estágio médio e com 12 anos de regeneração, localizado no município de Guaçuí-ES (parte inferior da foto), a 250 metros e abaixo da floresta matriz (parte superior da foto)

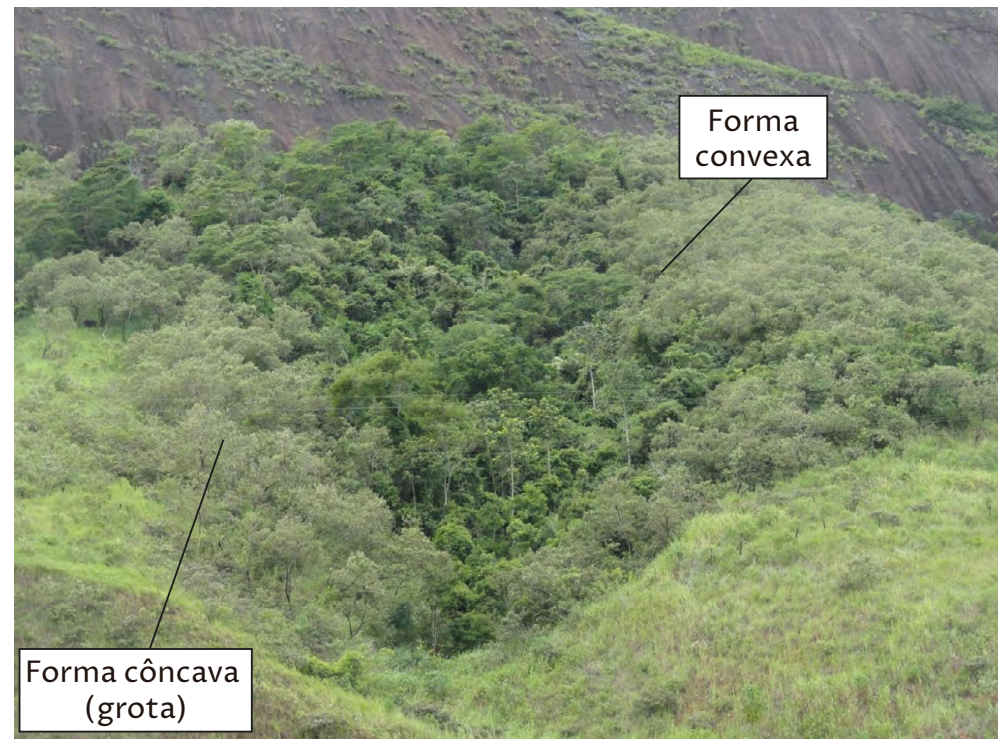

Figura 12 - Fragmento florestal localizado no município de Ibiraçu-ES, demonstrando as formas do relevo (côncava e convexa) 


\subsubsection{Presença de espécies-problema}

Em muitas áreas visitadas, as espécies-problema estavam dificultando ou impedindo a regeneração natural, pela sua agressividade ou alelopatia. Em áreas ocupadas por gramíneas em boa condição fisiológica, por samambaia (Pteridium aquilinum) e por espécies arbóreas nativas monodominantes, como a aroeira-do-sertão (Myracrodrum urundeuva) e o camará (Gochnatia polymorpha), por exemplo, observou-se que a regeneração natural foi prejudicada, pois essas espécies dificultam o estabelecimento de outras espécies e, portanto, prejudicam a diversidade necessária para a evolução do fragmento florestal.

Não é raro encontrar áreas com mais de duas décadas dominadas pelo camará, embora estejam muito próximas de florestas matrizes. E, como ressalta JORDANO et al. (2006), se as sementes são dispersadas em quantidade suficiente, porém são depositadas em locais de baixa qualidade (neste exemplo: uma área dominada pelo camará), então a regeneração é limitada.

Na Figura 13, estão demonstradas duas áreas, uma ocupada por camará (Gochnatia polymorpha) e a outra por aroeira-do-sertão (Myracrodrum urundeuva), sendo ambas com inibição da sucessão florestal.

\subsubsection{Ações antrópicas}

As ações antrópicas que mais influenciaram negativamente a regeneração natural foram a ocorrência de fogo e o pastoreio de bovinos. Foram observados alguns fragmentos florestais em processo de regeneração, os quais haviam sido queimados e nos quais, mesmo após vários anos de abandono, o estabelecimento da vegetação nativa e o avanço da sucessão estavam sendo prejudicados.

Em outras situações, observou-se que o gado, quando adentrava nos fragmentos florestais em regeneração, danificava as plântulas em emergência e praticamente eliminava o sub-bosque da floresta. Na Figura 14, estão demonstrados dois fragmentos florestais: um localizado no município de Guaçuí, ES, prejudicado pela ocorrência de fogo e que, mesmo após 30 anos de regeneração, apresenta baixa densidade de indivíduos e pouca estrutura; e o outro no município de Nova Venécia, onde o sub-bosque foi impactado por bovinos. 

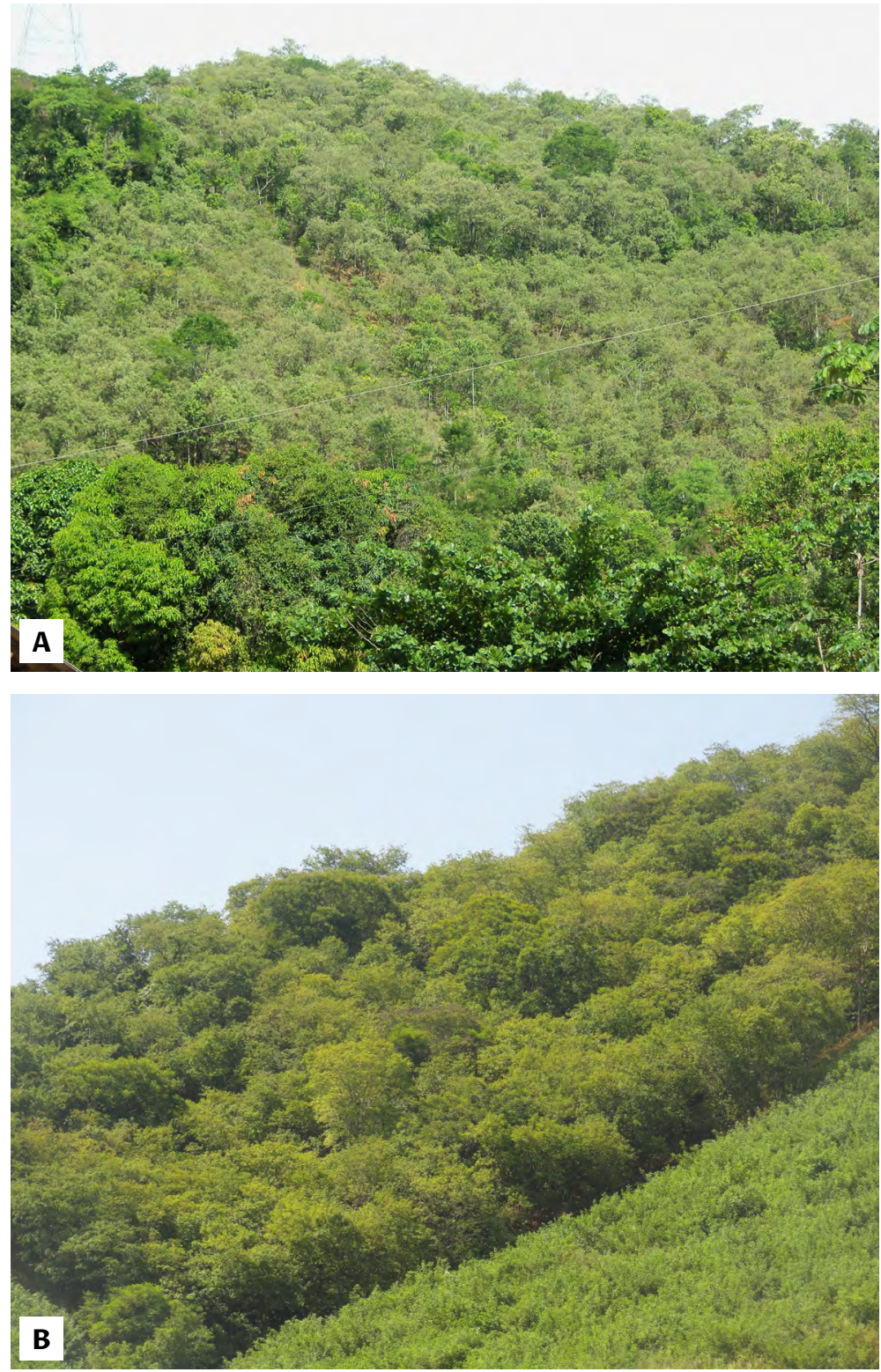

Figura 13 - Área com monodominância de camará (A) e aroeira-do-sertão (B) 

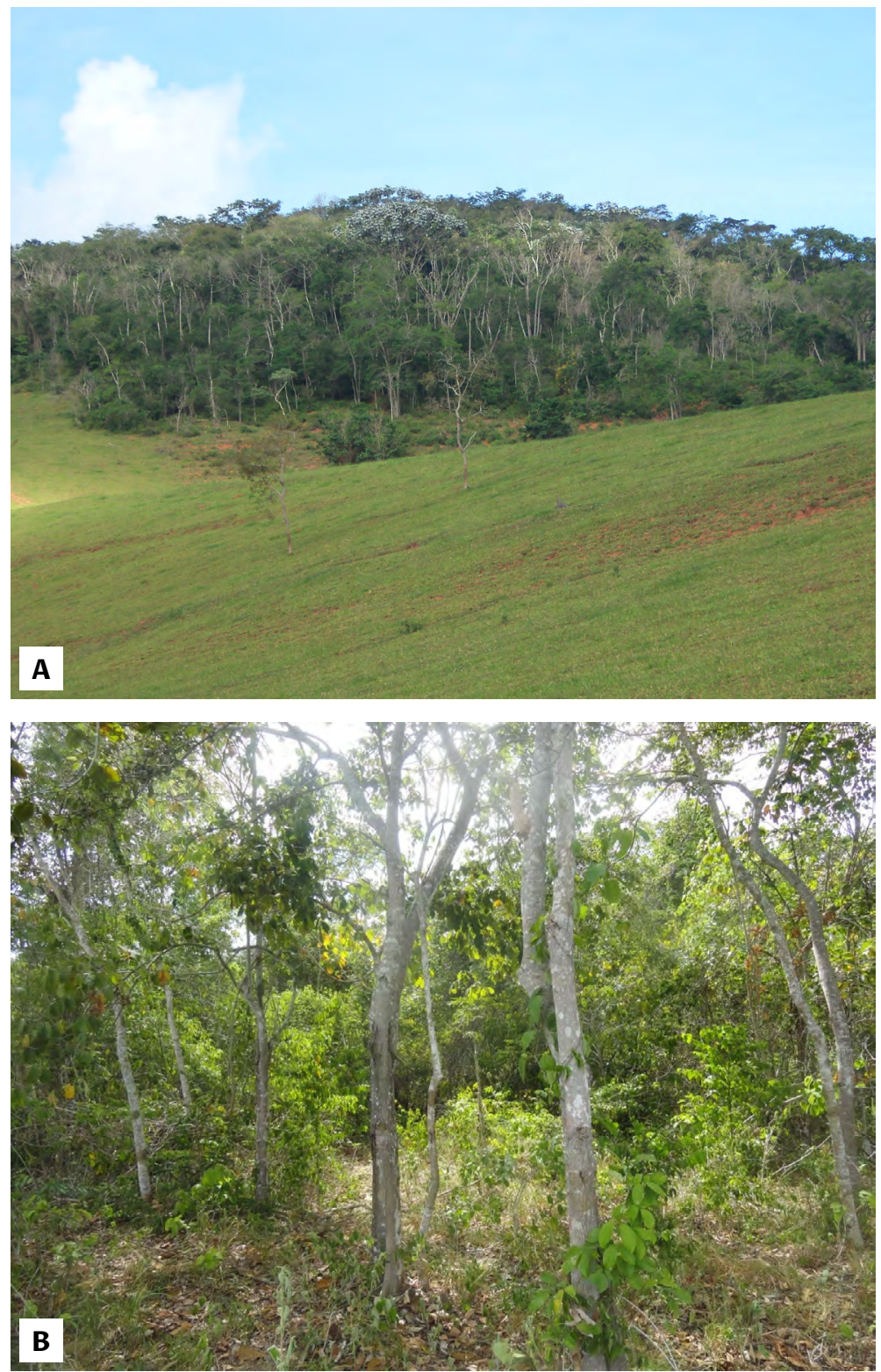

Figura 14 - Fragmentos florestais localizados no município de Guaçuí-ES (A), prejudicado pela ocorrência de fogo, e em Nova Venécia-ES (B), onde o sub-bosque foi impactado pelo gado bovino 


\subsubsection{Condições pedoclimáticas}

As condições pedoclimáticas influenciaram a velocidade da regeneração natural. Foi observado que fragmentos florestais ocupando solos de boa característica física e química, em regiões com boa distribuição de chuva e poucos meses secos, apresentavam melhor estrutura e diversidade.

Nas regiões que apresentavam um período mais pronunciado de meses secos, a regeneração natural ocorreu em outra dinâmica, porém essa condição não foi impeditiva para a sucessão ecológica, e espécies mais adaptadas ocupavam a área conforme demonstrado na Figura 15.

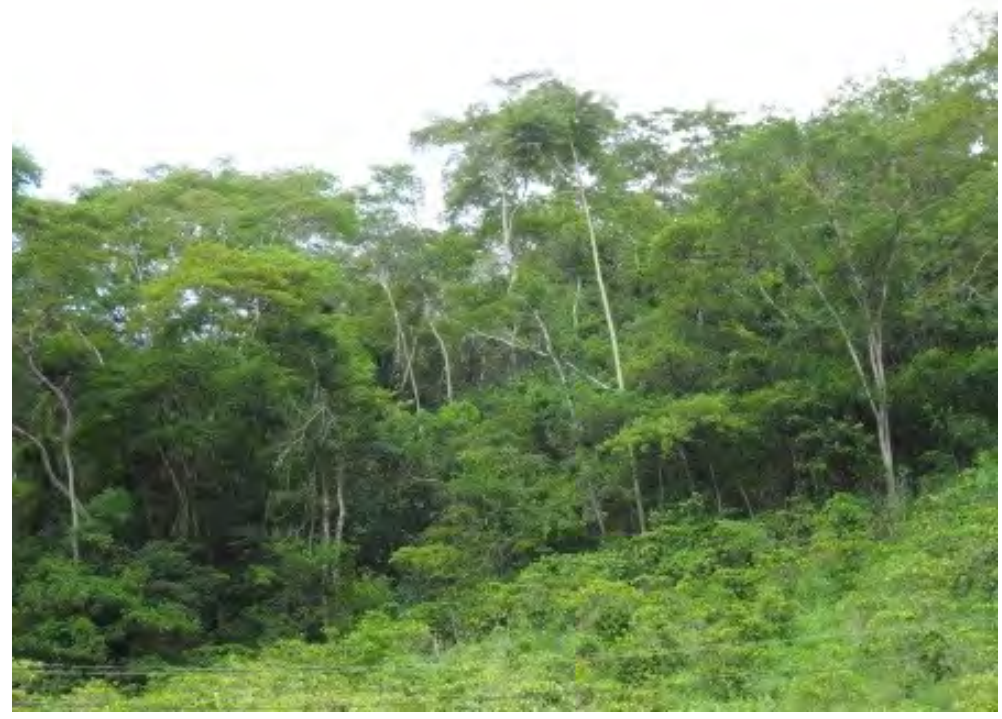

Figura 15 - Fragmento florestal localizado no município de Colatina-ES (município com 7 meses secos), em estágio médio de regeneração, com 22 anos de regeneração e alta densidade de angico (Anadenanthera colubrina)

\subsection{Dados das florestas regeneradas e florestas fornecedoras de propágulos (matrizes)}

Os dados das florestas fornecedoras de propágulos vegetativos, aqui denominadas florestas matrizes, bem como das florestas regeneradas, estão apresentados por zona nas Tabelas 4 e 5, respectivamente. 


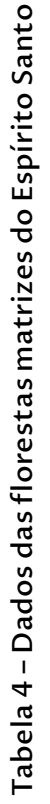
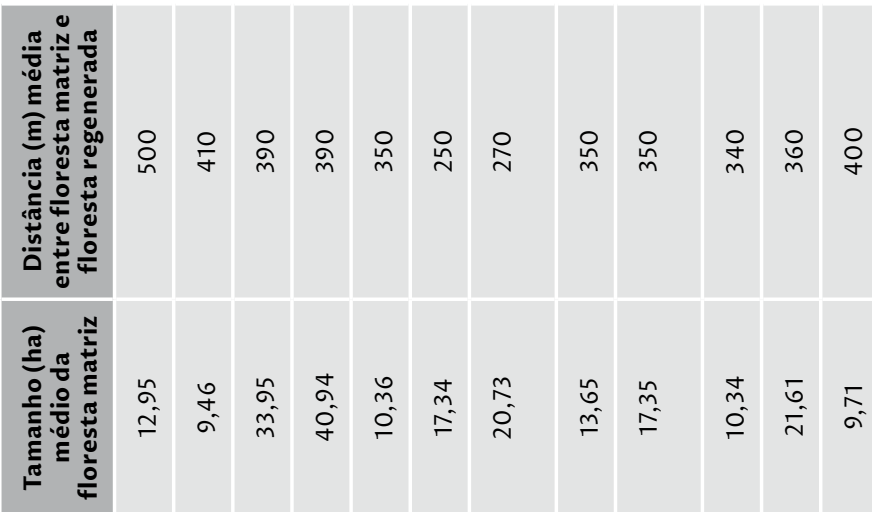

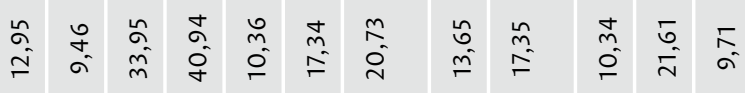

ํㅠ हี

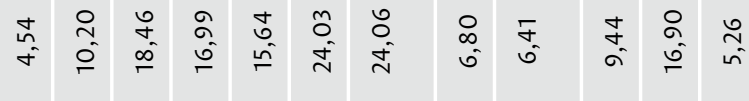

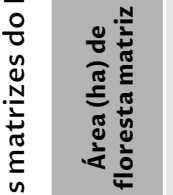

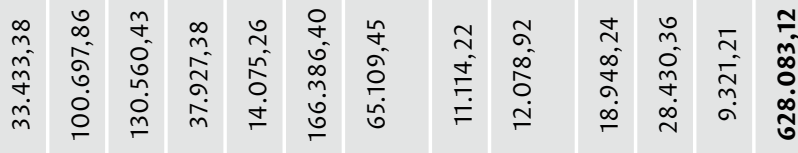

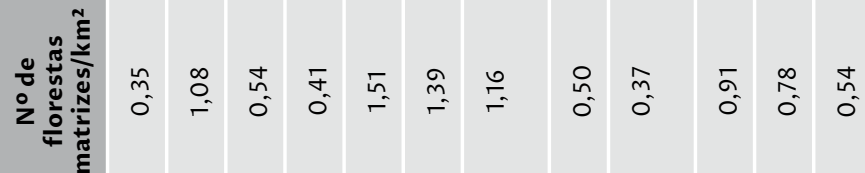

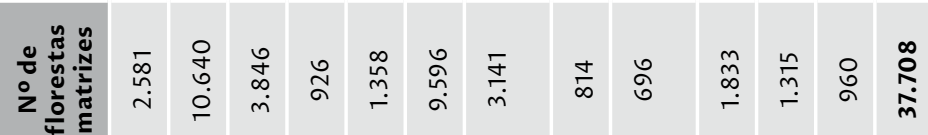

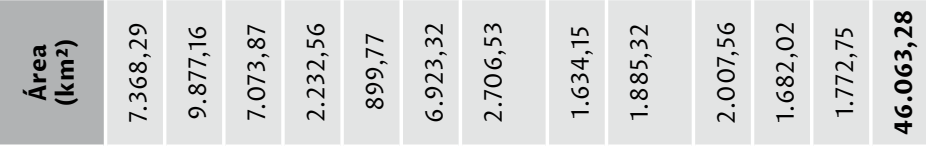

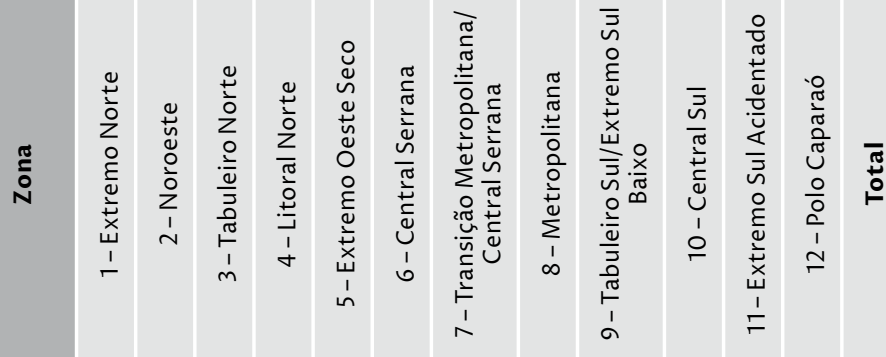




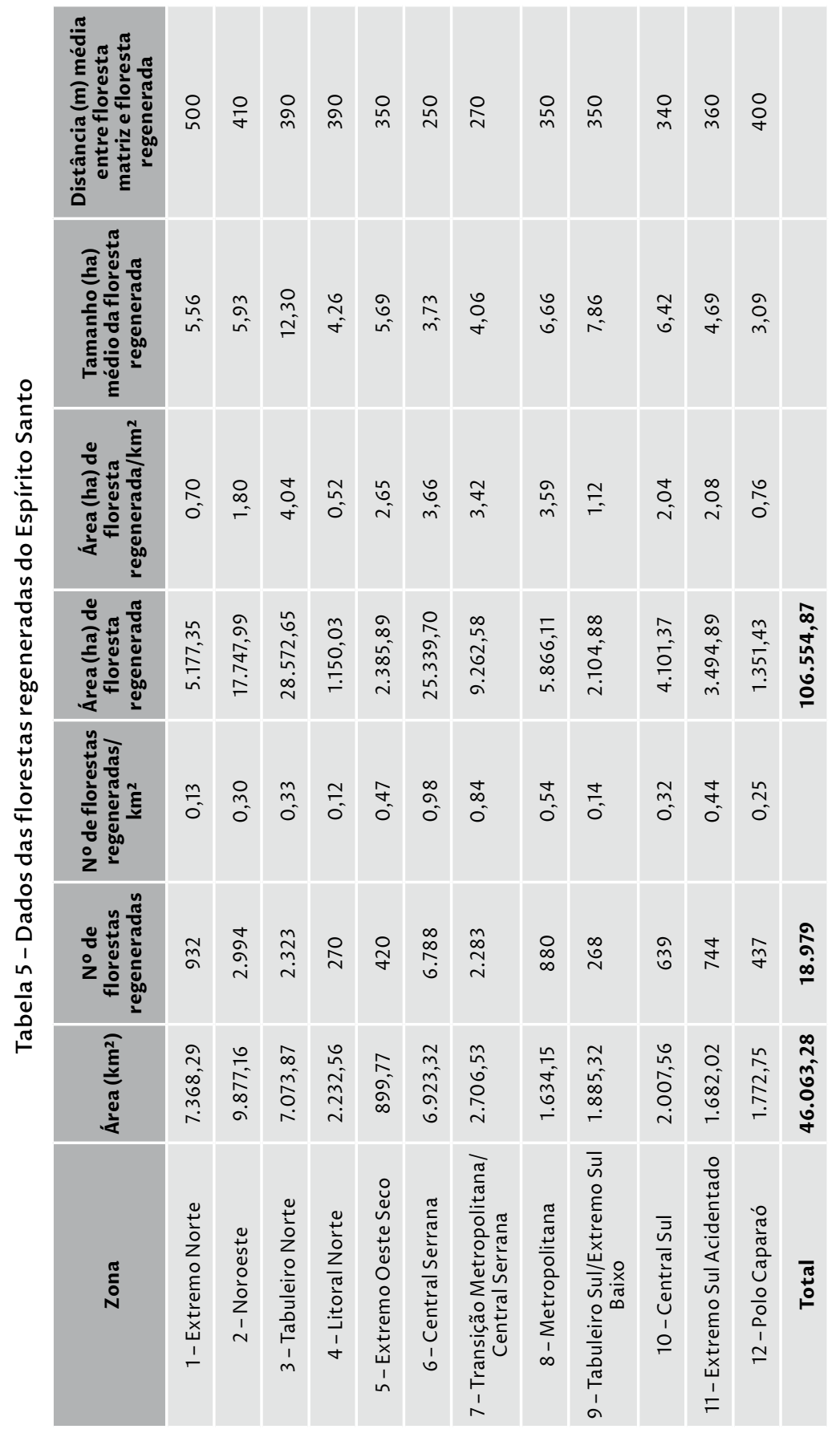


Observa-se, nas Tabelas 4 e 5, que existe uma correlação positiva entre o número de florestas regeneradas $/ \mathrm{km}^{2}$ e o número de florestas matrizes $/ \mathrm{km}^{2}(\mathrm{r}=0,71)$, o que indica que o maior número de fragmentos florestais fornecedores de propágulos influencia diretamente na regeneração natural. A relação entre esses fatores é preconizada por Ricklefs (2003), sendo observada também por outros pesquisadores.

A distância média entre floresta matriz e floresta regenerada correlacionou-se negativamente com o número de florestas regeneradas $/ \mathrm{km}^{2}$ $(r=-0,83)$. Quanto maior essa distância, menor é o número de florestas regeneradas, o que sugere a importância da proximidade entre as áreas objeto da regeneração natural e as florestas matrizes.

As menores distâncias médias entre floresta matriz e floresta regenerada foram observadas nas zonas Central Serrana e Transição Metropolitana/Central Serrana, apresentando valores de 270 e 250 metros, respectivamente (Figura 16).

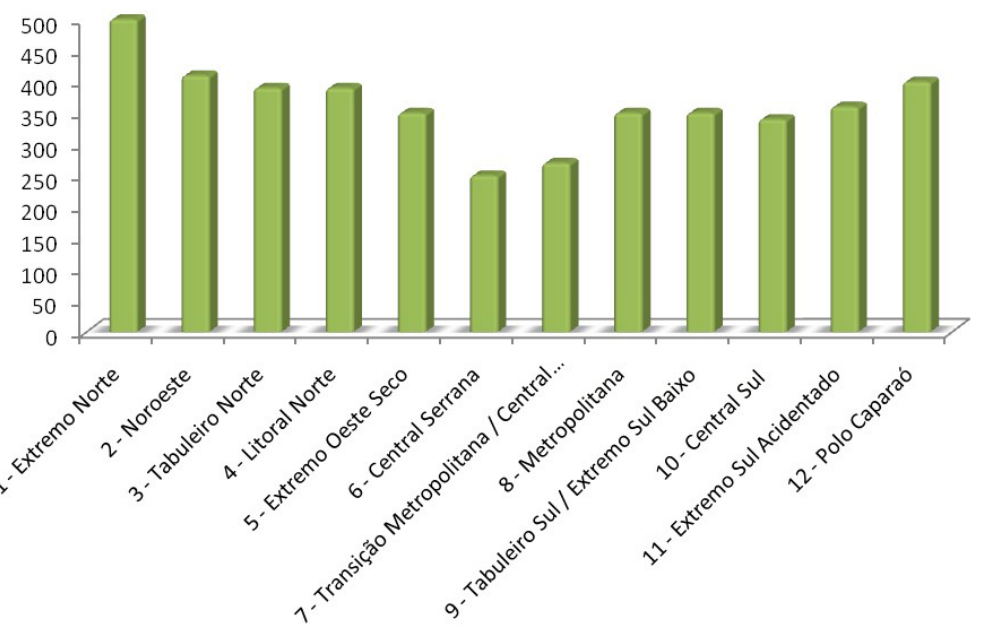

Figura 16 - Distância média (metros) entre floresta matriz e floresta regenerada

Uma possível explicação para essa constatação é que essas zonas estão inseridas em uma matriz florestal, onde existe grande quantidade de fragmentos florestais, aliada à característica fundiária, pois são zonas em que os imóveis rurais são de pequenas áreas.

As florestas regeneradas de maiores tamanhos estão presentes na zona Tabuleiro Norte (Figura 17), o que pode ter sido influenciado pelas grandes extensões das faixas de preservação permanente em processo de restauração existentes nessa região. 


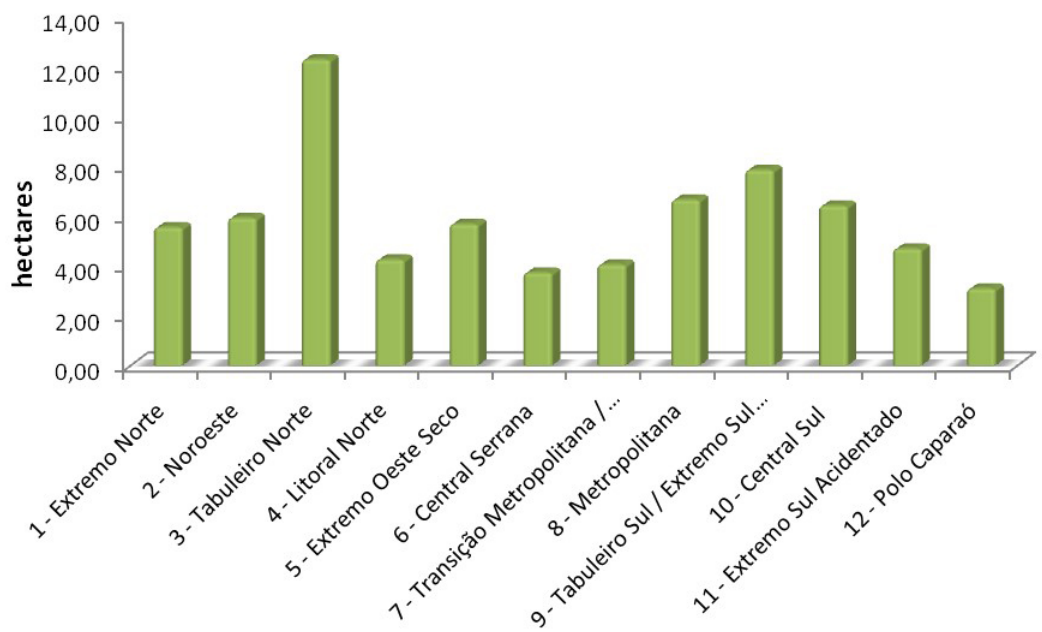

Figura 17 - Tamanho médio (hectares) das florestas regeneradas

Apesar de as zonas Central Serrana e Transição Metropolitana/ Central Serrana apresentarem o maior número de florestas regeneradas $/ \mathrm{km}^{2}$ (Figura 18), essas florestas são as de menores tamanhos, devido à predominância de imóveis rurais com pequenas áreas, o que leva à formação de florestas regeneradas fragmentadas e de pequenas dimensões. Cabe destacar que essas zonas são as que apresentam os maiores índices pluviométricos do estado, o que contribui para a regeneração natural.

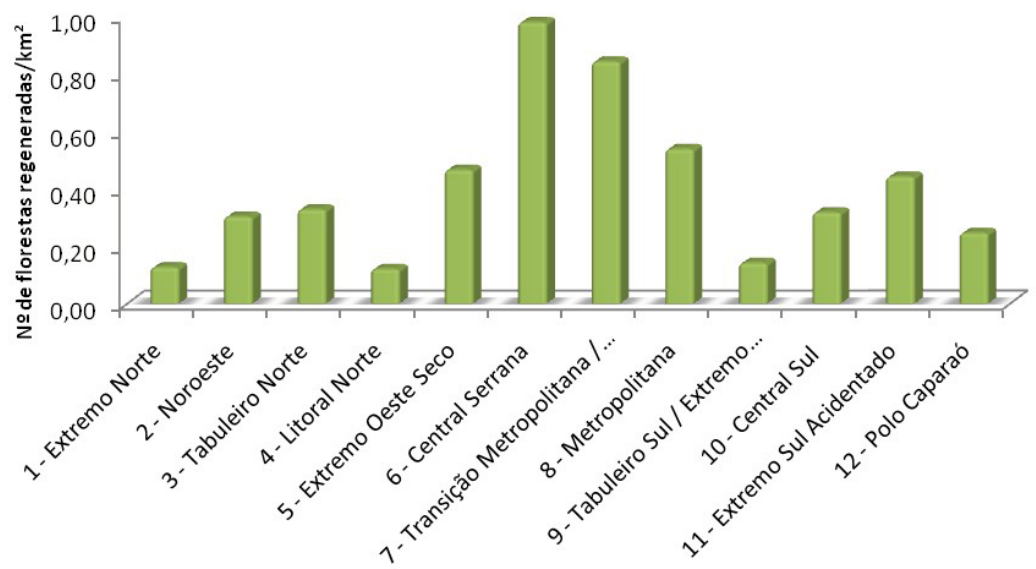

Figura 18 - Número de florestas regeneradas $/ \mathrm{km}^{2}$ 
Em contrapartida, as zonas Extremo Norte e Litoral Norte apresentaram os menores números de florestas regeneradas $/ \mathrm{km}^{2}$, sendo 0,13 floresta regenerada $/ \mathrm{km}^{2}$ na zona Extremo Norte e 0,12 floresta regene$\mathrm{rada} / \mathrm{km}^{2}$ na zona Litoral Norte (Figura 18 ).

Em se tratando de área de floresta regenerada $/ \mathrm{km}^{2}$, destaca-se a zona Tabuleiro Norte, com 4,04 ha/ $\mathrm{km}^{2}$ (Figura 19), onde estão inseridas a Reserva Natural Vale, a Reserva Biológica de Sooretama e as áreas da empresa Fibria, sugerindo que a restauração das áreas de preservação permanente tenha influenciado esse parâmetro. Esse valor de regeneração é significativo, pois se pode considerar que, nos últimos 33 anos, $4,04 \%$ da área total dessa zona se regeneraram naturalmente.

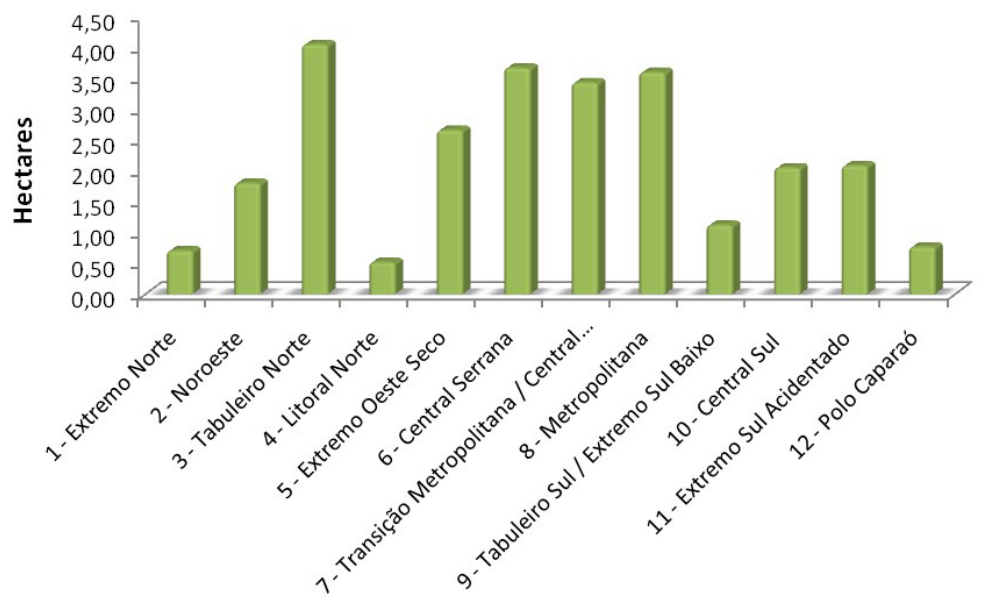

Figura 19 - Área (hectares) de floresta regenerada $/ \mathrm{km}^{2}$

As zonas Central Serrana e Transição Metropolitana/Central Serrana também obtiveram valores elevados em termos de área de floresta regenerada/ $\mathrm{km}^{2}$ (3,66 e 3,42 hectares de floresta regenerada/ $\mathrm{km}^{2}$, respectivamente), apesar de ligeiramente inferiores ao da zona Tabuleiro Norte, o que pode ser explicado pelo grande número de florestas regeneradas $/ \mathrm{km}^{2}$ que essas zonas apresentaram.

As zonas Central Serrana e Transição Metropolitana/Central Serrana se destacaram no que se refere a área de floresta matriz $/ \mathrm{km}^{2}$ (Figura 20). Em compensação, a zona Extremo Norte apresentou a menor área de floresta matriz $/ \mathrm{km}^{2}\left(4,54 \mathrm{ha} / \mathrm{km}^{2}\right)$ e também o menor número de floresta matriz $/ \mathrm{km}^{2}\left(0,35\right.$ florestas $\left./ \mathrm{km}^{2}\right)$, demonstrando sua baixa capacidade de regeneração natural, em função da baixa disponibilidade de fragmentos florestais fornecedores de propágulos. 


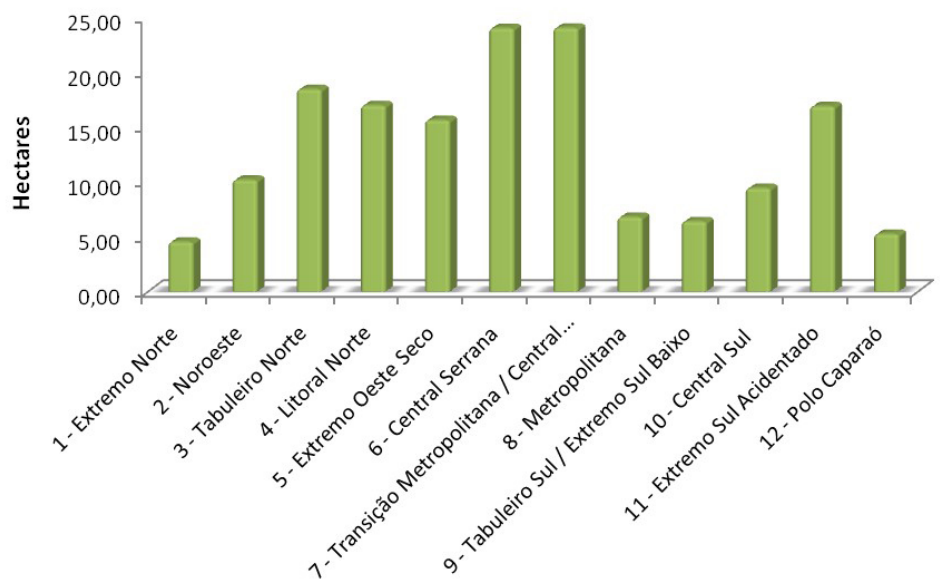

Figura 20 - Área (hectares) de floresta matriz $/ \mathrm{km}^{2}$

Cabe destacar, de forma geral, que o número de floresta regenerada/ $\mathrm{km}^{2}$ e a velocidade da regeneração natural foram maiores nas zonas que apresentam os maiores índices pluviométricos.

Como resultado consolidado observado na Tabelas 4 e 5, nos últimos 33 anos 18.979 florestas se regeneraram no Estado do Espírito Santo, ocupando uma área de 106.554,87 hectares. Para as florestas matrizes, existem 37.708 fragmentos, que ocupam uma área de 628.083,12 hectares, o que corresponde a $13,64 \%$ da área total do Espírito Santo.

\subsection{Classificação das Zonas de acordo com o potencial de Regeneração Natural}

Na Tabela 6, consta o percentual da nota obtida pelas zonas estudadas em relação à nota hipoteticamente obtida por uma zona ideal, bem como as respectivas classificações. Já na Figura 21, está o mapa com a classificação das zonas de acordo com o seu potencial de regeneração natural.

Tabela 6 - Classificação do potencial de regeneração natural por zona

\begin{tabular}{|c|c|c|}
\hline Zona & $\begin{array}{c}\text { Percentual da nota obtida pela } \\
\text { zona estudada em relação à } \\
\text { nota hipoteticamente obtida } \\
\text { por uma área ideal }\end{array}$ & $\begin{array}{c}\text { Classificação do } \\
\text { potencial de } \\
\text { regeneração natural }\end{array}$ \\
\hline $1-$ Extremo Norte & 26,67 & Baixo \\
\hline 2 - Noroeste & 66,67 & Transição médio/alto \\
\hline
\end{tabular}




\begin{tabular}{|c|c|c|}
\hline 3- Tabuleiro Norte & 60,00 & Médio \\
\hline 4 - Litoral Norte & 33,33 & Baixo \\
\hline 5 - Extremo Oeste Seco & 73,33 & Transição médio/alto \\
\hline 6-Central Serrana & 93,33 & Alto \\
\hline 7- Transição Metropolitana/ \\
Central Serrana
\end{tabular}

O percentual da área total de uma zona natural com potencial para receber propágulos está demonstrado na Tabela 7.

\section{Tabela 7 - Percentual da área total de cada zona com potencial para receber propágulos}

\begin{tabular}{|c|c|}
\hline Zona & $\begin{array}{l}\text { Percentual }(\%) \text { da área de cada } \\
\text { zona que tem potencial para } \\
\text { receber propágulos }\end{array}$ \\
\hline 1-Extremo Norte & 37,70 \\
\hline 2 - Noroeste & 70,23 \\
\hline 3 -Tabuleiro Norte & 63,81 \\
\hline 4 - Litoral Norte & 49,00 \\
\hline 5 - Extremo Oeste Seco & 78,14 \\
\hline 6 - Central Serrana & 80,26 \\
\hline 7 - Transição Metropolitana/Central Serrana & 72,00 \\
\hline 8 - Metropolitana & 42,67 \\
\hline 9 - Tabuleiro Sul/Extremo Sul Baixo & 35,00 \\
\hline $10-$ Central Sul & 49,02 \\
\hline 11 - Extremo Sul Acidentado & 73,15 \\
\hline 12 - Polo Caparaó & 45,12 \\
\hline
\end{tabular}




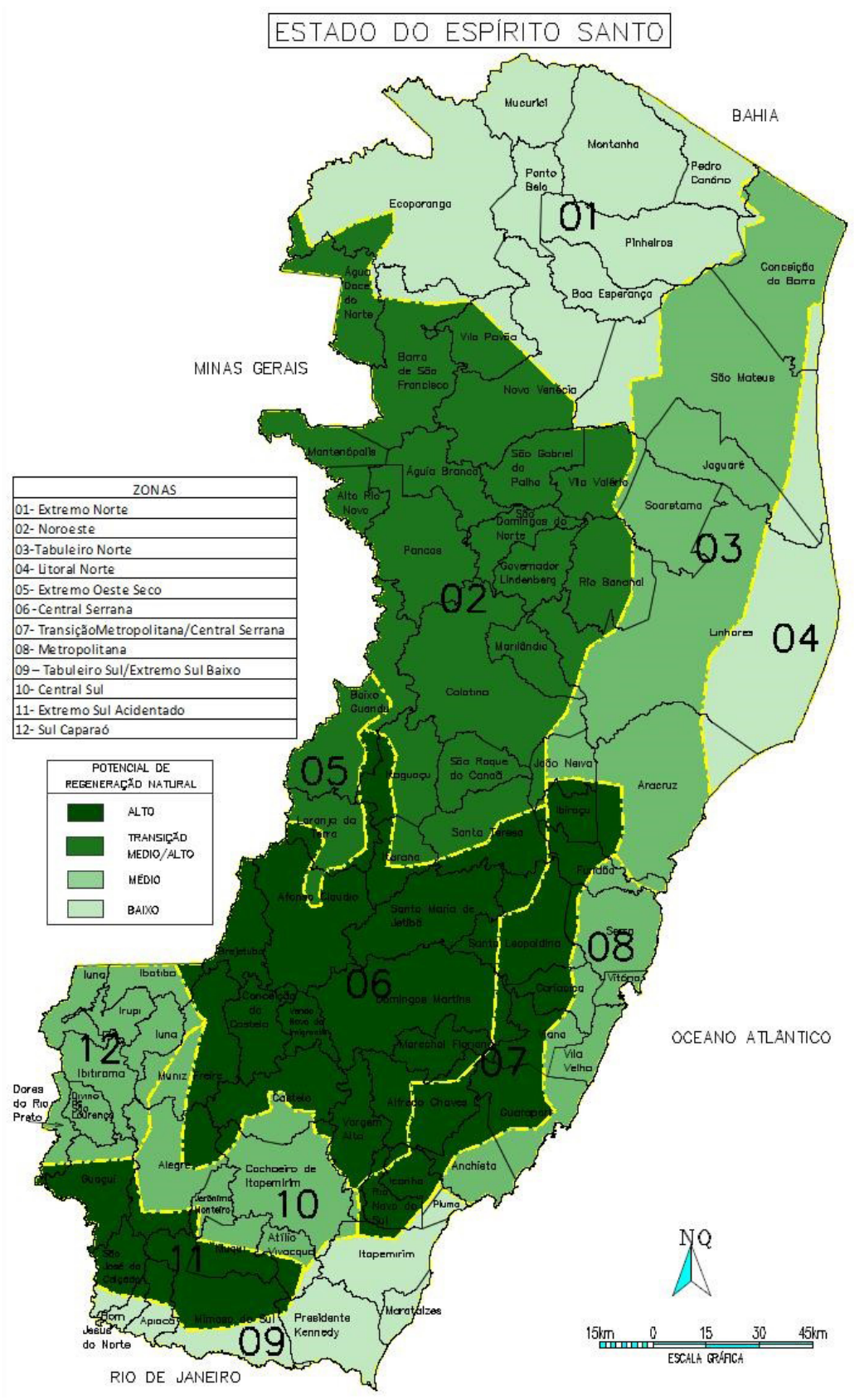

Figura 21 - Mapa de classificação do potencial de regeneração natural do Espírito Santo 
Segundo consta nas Tabelas 4 e 7, há uma forte correlação positiva $(\mathrm{r}=0,87)$ entre o número de florestas matrizes $/ \mathrm{km}^{2}$ e o percentual da área de cada zona com potencial para receber propágulos, em função da menor distância entre fonte (matriz) e o local, consequentemente aumentando os valores percentuais demonstrados na Tabela 7.

A multiplicação do valor percentual demonstrado na Tabela 7 pela área de determinada zona (Tabela 4) corresponde à área com potencial de receber propágulos. O somatório das áreas de todas as zonas que têm potencial para receber propágulos gerou um produto que se traduz na área total do Estado do Espírito Santo que apresenta alto potencial de regeneração natural em função de sua proximidade com uma floresta potencial fornecedora de propágulos. Com isso, tem-se um resultado em que 2.804.431 hectares do Estado do Espírito Santo possuem alto potencial de regeneração natural, o que representa $60,88 \%$ da sua área total.

\subsection{Caracterização florística das áreas regeneradas do Espírito Santo}

\subsubsection{Geral}

Conforme o critério estabelecido na metodologia para os estudos de campo, foram visitadas 70 áreas que integram as diferentes regiões e ecossistemas do Espírito Santo.

Apresenta-se na Tabela 8 a lista florística das principais espécies arbóreas das áreas regeneradas do Espírito Santo, onde foram identificadas 115 espécies arbóreas nativas, que pertencem a 43 famílias botânicas.

Tabela 8 - Lista florística das principais espécies arbóreas encontradas nas áreas regeneradas do Espírito Santo

\begin{tabular}{|c|c|c|}
\hline Família & Espécie & Nome vulgar \\
\hline Achariaceae & Carpotroche brasiliensis (Raddi) Endl. & Canudo-de-pito \\
\hline Anacardiaceae & Astronium conccinum Schott. & Conçalo-alves \\
\hline Anacardiaceae & Astronium graveolens Jacq. & Aderne \\
\hline Anacardiaceae & Schinus terebinthifolius Raddi & Aroeira \\
\hline Anacardiaceae & Spondias mombin L. & Tabuá \\
\hline Anacardiaceae & Tapirira guianensis Aubl. & Cupuba \\
\hline
\end{tabular}




\begin{tabular}{|c|c|c|}
\hline Anacardiaceae & Myracrodruon urundeuva Allemão & Aroeira-do-sertão \\
\hline Annonaceae & Annona acutiflora Mart. & Ariticum \\
\hline Annonaceae & Xylopia sericea A. St.-Hil. & Pindaíba \\
\hline Apocynaceae & Himatanthus sp. & \\
\hline Apocynaceae & Tabernaemontana laeta (Mart.) Miers & Leiteira \\
\hline Arecaceae & $\begin{array}{l}\text { Astrocaryum aculeatissimum (Schott) } \\
\text { Burret }\end{array}$ & Brejaúba \\
\hline Arecaceae & Attalea dubia (Mart.) Burret & Indaiá-açu \\
\hline Arecaceae & Attalea humilis Mart. & Indaiá \\
\hline Arecaceae & Attalea oleifera Barb. Rodr. & Pindoba \\
\hline Arecaceae & Bactris sp. & \\
\hline Arecaceae & Elaeis guineensis Jacq. & Dendê \\
\hline Arecaceae & Euterpe edulis Mart. & Palmito-juçara \\
\hline Arecaceae & $\begin{array}{l}\text { Polyandrococos caudescens (Mart.) Barb. } \\
\text { Rodr. }\end{array}$ & Palmito-amargoso \\
\hline Arecaceae & Syagrus botryophora (Mart.) Mart. & Jerivá \\
\hline Asteraceae & Gochnatia polymorpha (Less.) Cabrera & Camará \\
\hline Bignoniaceae & $\begin{array}{l}\text { Handroanthus chrysotrichus (Mart. ex A. } \\
\text { DC.) Mattos }\end{array}$ & Ipê-amarelo \\
\hline Bignoniaceae & Jacaranda nitida A. DC. & Carobinha \\
\hline Bignoniaceae & Jacaranda puberula Cham. & Caroba \\
\hline Bignoniaceae & $\begin{array}{c}\text { Paratecoma peroba (Record \& Mell.) } \\
\text { Kuhlm. }\end{array}$ & Peroba \\
\hline Bignoniaceae & $\begin{array}{l}\text { Sparattosperma leucanthum (Vell.) K. } \\
\text { Schum. }\end{array}$ & Cinco-folhas \\
\hline Bignoniaceae & Tabebuia cassinoides (Lam.) DC. & Caixeta \\
\hline Bignoniaceae & Tabebuia sp. & Ipê \\
\hline Bignoniaceae & Zeyheria tuberculosa (Vell.) Bureau & Ipê-felpudo \\
\hline Burseraceae & Protium heptaphyllum (Aubl.) Marchand & Almescla \\
\hline Cactaceae & Pereskia sp. & Ora-pro-nóbis \\
\hline Cannabaceae & Trema micrantha (L.) Blume & Candiúva \\
\hline Celastraceae & Maytenus obtusifolia Mart. & Café-ciliar \\
\hline Combretaceae & Terminalia catappa L. & Castanha-da-praia \\
\hline Combretaceae & Terminalia kuhlmannii Alwan \& Stace & Pelada \\
\hline Connaraceae & Connarus sp. & \\
\hline Cyatheaceae & Cyathea poeppigii (Hook.) Domin & Samambaiaçu \\
\hline
\end{tabular}




\begin{tabular}{|c|c|c|}
\hline Euphorbiaceae & Alchornea triplinervia (Spreng.) Müll. Arg. & \\
\hline Euphorbiaceae & Cnidoscolus oligandrus (Müll. Arg.) Pax & Ardiabo \\
\hline Euphorbiaceae & Crotonsp. & \\
\hline Euphorbiaceae & Croton urucurana Baill. & sangue-de-drago \\
\hline Euphorbiaceae & Joannesia princeps Vell. & Boleira \\
\hline Euphorbiaceae & Senefeldera verticillata (Vell.) Croizat & Sucanga \\
\hline Fabaceae & Anadenanthera colubrina (Vell.) Brenan & Angico \\
\hline Fabaceae & Andira fraxinifolia Benth. & Angelim-coco \\
\hline Fabaceae & Andira nitida Mart. ex Benth. & Angelim-de-morcego \\
\hline Fabaceae & Apuleia leiocarpa (Vogel) J. F. Macbr. & Garapa \\
\hline Fabaceae & Dalbergia nigra (Vell.) Allemao ex Benth. & Jacarandá \\
\hline Fabaceae & Hymenaea courbaril L. & Jatobá \\
\hline Fabaceae & Inga edulis Mart. & Ingá \\
\hline Fabaceae & Inga laurina (Sw.) Willd. & \\
\hline Fabaceae & Machaerium fulvovenosum H. C. Lima & Jacarandá-cipó \\
\hline Fabaceae & Machaerium hirtum (Vell.) Stellfeld & Jacarandá-bico-de-pato \\
\hline Fabaceae & Newtonia contorta (DC.) Burkart & Angico-de-minas \\
\hline Fabaceae & Peltophorum dubium (Spreng.) Taub. & Angico-cangalha \\
\hline Fabaceae & $\begin{array}{l}\text { Piptadenia gonoacantha (Mart.) J. F. } \\
\text { Macbr. }\end{array}$ & Pau-jacaré \\
\hline Fabaceae & Plathymenia foliolosa Benth. & Vinhático \\
\hline Fabaceae & Schizolobium parahyba (Vell.) S. F. Blake & Guapuruvu \\
\hline Fabaceae & Senegalia polyphylla (DC.) Britton & Maricá \\
\hline Fabaceae & $\begin{array}{c}\text { Senna australis (Vell.) H. S. Irwin \& } \\
\text { Barneby }\end{array}$ & Fedegoso \\
\hline Fabaceae & Swartzia apetala Raddi & \\
\hline Fabaceae & Swartzia flaemingii Raddi & Falso-jacarandá \\
\hline Fabaceae & Zollernia glabra (Spreng.) Yakovlev & Pitombinha \\
\hline Hypericaceae & Vismia ferruginea Kunth & \\
\hline Lamiaceae & Aegiphila sellowiana Cham. & Mululo \\
\hline Lamiaceae & Vitex montevidensis Cham. & Tarumã \\
\hline Lauraceae & Ocotea sp. & Canela \\
\hline Lecythidaceae & Cariniana legalis (Mart.) Kuntze & Jequitibá-rosa \\
\hline Lecythidaceae & Eschweilera ovata (Cambess.) Miers & Imbiriba \\
\hline Lecythidaceae & Lecythis pisonis Cambess. & Sapucaia \\
\hline
\end{tabular}




\begin{tabular}{|c|c|c|}
\hline Malpighiaceae & Byrsonima sericea DC. & Murici-do-brejo \\
\hline Malvaceae & Chorisia speciosa A. St.-Hil. & Paineira \\
\hline Malvaceae & Luehea mediterranea (Vell.) Angely & Açoita-cavalo \\
\hline Malvaceae & Pterygota brasiliensis Allemão & Farinha-seca \\
\hline Melastomataceae & Miconia albicans (Sw.) Triana & Quaresma-da-mussununga \\
\hline Melastomataceae & Miconia prasina (Sw.) DC. & Ferreira-leite \\
\hline Melastomataceae & Tibouchina arborea (Gardner) Cogn. & Quaresmeira-branca \\
\hline Melastomataceae & Tibouchina granulosa (Desr.) Cogn. & Quaresmeira-roxa \\
\hline Meliaceae & Cedrela fissilis Vell. & Cedro-rosa \\
\hline Meliaceae & Guarea guidonia (L.) Sleumer & Peloteira \\
\hline Moraceae & Artocarpus heterophyllus Lam. & Jaqueira \\
\hline Moraceae & Ficus sp. & Figueira \\
\hline Moraceae & Maclura tinctoria (L.) D. Don ex Steud. & Moreira \\
\hline Myrsinaceae & Myrsine umbellata Mart. & Capororoca-cinza \\
\hline Myrtaceae & Myrcia fallax (Rich.) DC. & Batinga-roxa \\
\hline Myrtaceae & Myrcia vittoriana Kiaersk. & Batinga-da-mussununga \\
\hline Nyctaginaceae & Bougainvillea spectabilis Willd. & Buganvile \\
\hline Peraceae & Pera glabrata (Schott) Baill. & Cinta-larga \\
\hline Phytolacaceae & Gallesia integrifolia (Spreng.) Harms & Pau-d'alho \\
\hline Polygonaceae & Coccoloba sp. & \\
\hline Rhamnaceae & Ziziphus platyphyllus Reissek & Joazeiro \\
\hline Rubiaceae & Genipa americana L. & Genipapo \\
\hline Rutaceae & Dictyoloma vandellianum A. H. L. Juss. & \\
\hline Rutaceae & Metrodorea nigra A. St.-Hil. & Carrapateira \\
\hline Rutaceae & Zanthoxylum aff. tingoassuiba A. St.-Hil. & \\
\hline Rutaceae & Zanthoxylum rhoifolium Lam. & Mamica-de-porca \\
\hline Salicaceae & Casearia commersoniana Cambess. & Língua-de-velho \\
\hline Salicaceae & Casearia sylvestris Sw. & Cafezinho-do-mato \\
\hline Sapindaceae & Cupania emarginata Cambess. & \\
\hline Sapindaceae & Cupania rugosa Radlk. & Pau-magro \\
\hline Sapindaceae & Cupania sp. & \\
\hline Sapindaceae & Matayba guianensis Aubl. & Pitomba-rosa \\
\hline Simaroubaceae & Simarouba amara Aubl. & Caxeta \\
\hline Siparunaceae & Siparuna arianeae V. Pereira & Negamina \\
\hline
\end{tabular}




\begin{tabular}{|c|c|c|}
\hline Solanaceae & Cestrum axillare Vell. \\
\hline Solanaceae & Solanum pseudoquina A. St.-Hil. & Joá-quina \\
\hline Solanaceae & Solanum sp. \\
\hline Urticaceae & Cecropiaglaziovii Snethl. & Embaubão \\
\hline Urticaceae & Cecropiahololeuca Miq. & Embaúba-branca \\
\hline Urticaceae & Cecropia pachystachya Trécul. & Embaúba \\
\hline Verbenaceae & Vitex montevidensis Cham. & Tarumã \\
\hline Vochysiaceae & Vochysia tucanorum Mart. & Angélica \\
\hline
\end{tabular}

As espécies presentes no maior número de áreas foram: Cecropia pachystachya Trécul. (Embaúba), encontrada em 39 áreas; Anadenanthera colubrina (Vell.) Brenan (Angico), encontrada em 31 áreas; Sparattosperma leucanthum (Vell.) K. Schum. (Cinco-folhas), encontrada em 23 áreas; Piptadenia gonoacantha (Mart.) J. F. Macbr. (Pau-jacaré), encontrada em 22 áreas; e Aegiphila sellowiana Cham. (Mululo), encontrada em 17 áreas.

Nas áreas visitadas, 21 espécies foram consideradas fisionomicamente dominantes, sendo que Anadenanthera colubrina (Vell.) Brenan (Angico) foi considerada dominante em 14 áreas e Piptadenia gonoacantha (Mart.) J. F. Macbr. (Pau-jacaré) em 12 áreas.

As famílias mais representativas em relação ao número de espécies foram Fabaceae (21 espécies), Arecaceae (10) e Bignoniaceae (8 espécies) (Figura 22). A presença de Fabaceae como a família mais importante, em relação à riqueza, corrobora as análises de Gentry (1988), que destaca essa família como uma das mais importantes para as florestas neotropicais. Também se trata de uma das mais importantes famílias em áreas regeneradas no Espírito Santo, como as estudadas por Simonelli et al. (2010).

Em relação ao estágio sucessional (Figura 23), constatou-se que a maior parte das áreas estudadas (72\%) já se encontra em estágio médio de regeneração da Mata Atlântica, compondo florestas de boa estrutura. Isso demonstra que, apesar do pouco tempo (algumas áreas com 12 anos), as florestas do Espírito Santo apresentam, no geral, elevada velocidade de regeneração.

Quanto à riqueza de espécies (Figura 24), observa-se que a maior parte das áreas estudadas (61\%) apresenta mais que 20 espécies arbóreas, demonstrando que a regeneração está contribuindo para a manutenção da biodiversidade local. 


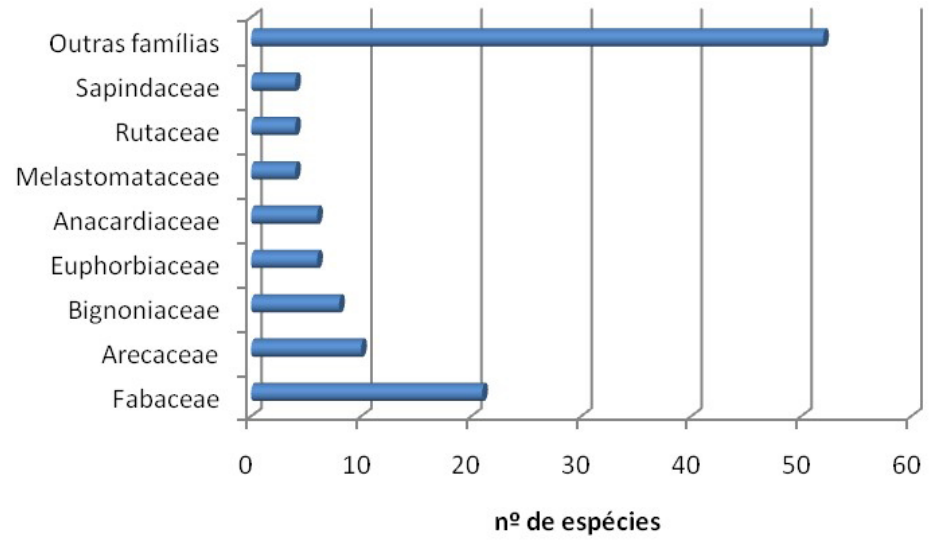

Figura 22 - Famílias mais representativas em riqueza de espécies arbóreas encontradas em áreas regeneradas do Espírito Santo

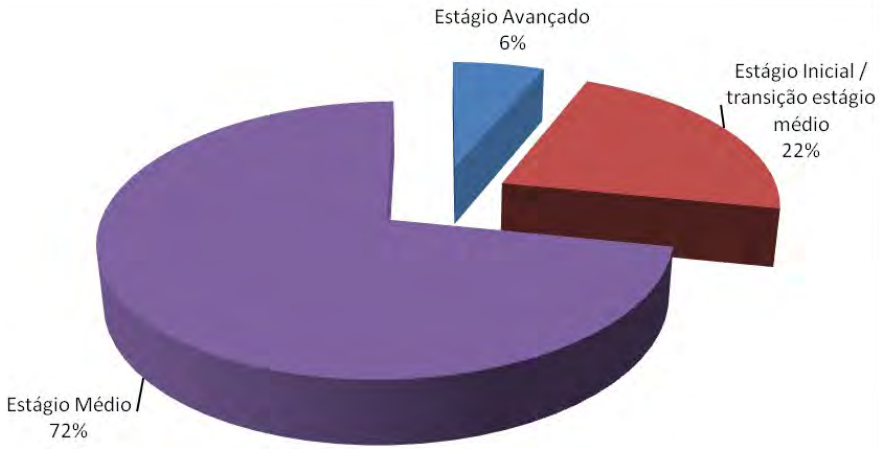

Figura 23 - Estágio sucessional das áreas regeneradas do Espírito Santo

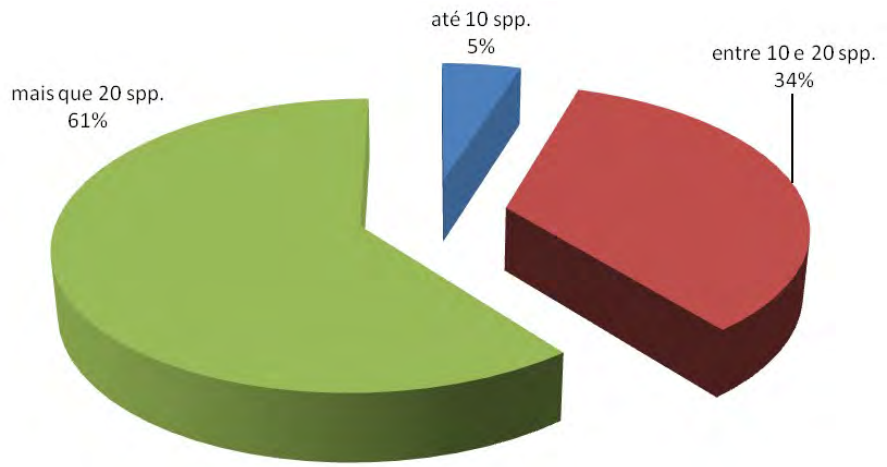

Figura 24 - Riqueza das áreas regeneradas do Espírito Santo 
A altura média do dossel das áreas regeneradas foi de 7,4 metros, sendo que a maior parte das áreas apresentou entre 6 e 8 metros de altura média do dossel (Figura 25).

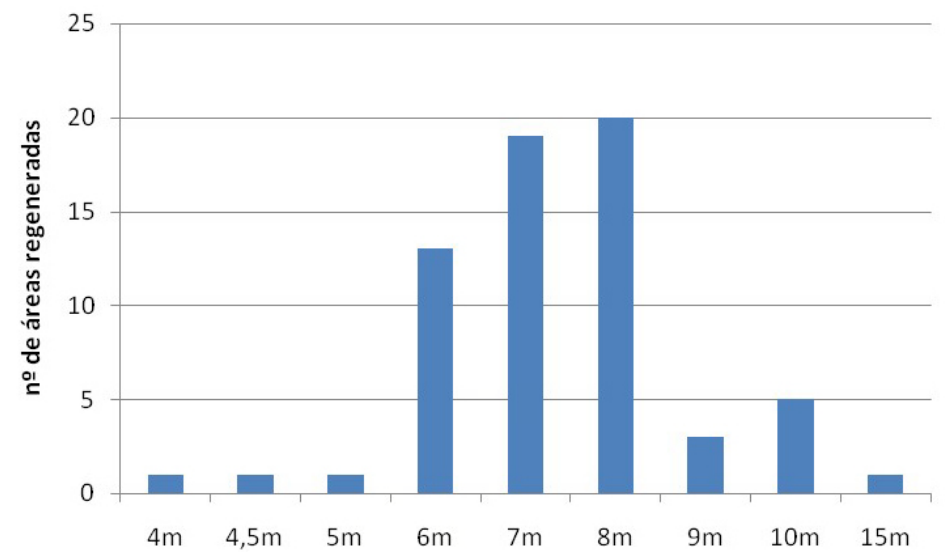

Figura 25 - Distribuição das alturas médias das áreas regeneradas do Espírito Santo

Já o epifitismo encontrado nas áreas foi considerado baixo. Em apenas $11,4 \%$ das áreas estudadas foram encontradas epífitas e geralmente da família Bromeliaceae (principalmente do gênero Tillandsia).

Em relação ao grupo ecológico das espécies encontradas, pode-se observar na Figura 26 que o grupo das secundárias iniciais foi o mais frequente, seguido pelo das secundárias tardias e pioneiras.
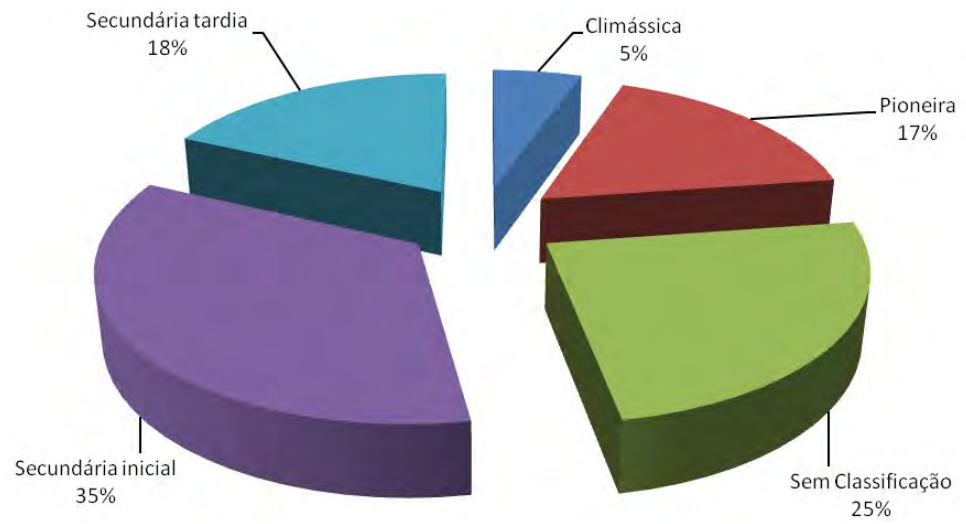

Figura 26-Grupos ecológicos das espécies encontradas nas áreas regeneradas do Espírito Santo 
A maior parte (61\%) das espécies encontradas possui síndrome de dispersão zoocórica, seguida da anemocoria, com 34\% (Figura 27). A riqueza de espécies zoocóricas demonstra a importância dos animais (principalmente aves e morcegos) na formação de florestas regeneradas. Em contrapartida, também mostra a importância dessas matas na atração e na manutenção de espécies animais, contribuindo assim para a manutenção da biodiversidade local.

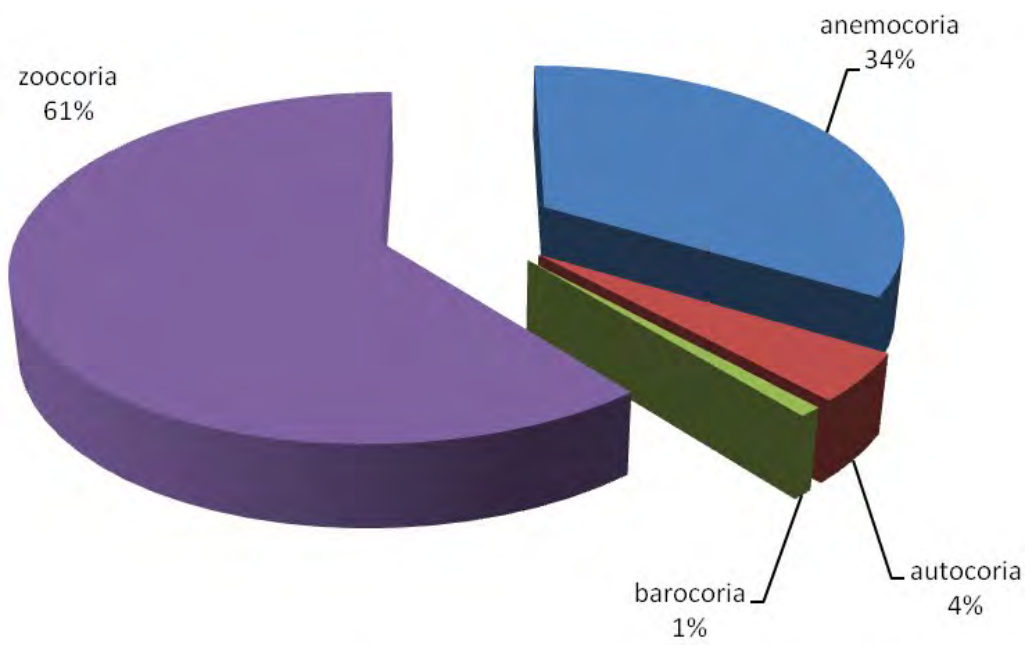

Figura 27 - Síndromes de dispersão das espécies encontradas nas áreas regeneradas do Espírito Santo

\subsubsection{Por zona}

\subsubsection{Zona Extremo Norte}

Nessa zona, foram identificadas 18 espécies arbóreas nativas. As espécies observadas no maior número de áreas foram Sparattosperma leucanthum (Cinco-folhas) e Machaerium hirtum (Jacarandá-bico-de-pato), encontradas em $75 \%$ das áreas.

Nas áreas visitadas, 5 espécies apresentaram-se fisionomicamente dominantes, sendo que Machaerium hirtum (Vell.) Stellfeld (Jacarandábico-de-pato) foi considerada dominante em $50 \%$ das áreas.

Em relação à riqueza de espécies (Figura 28), observa-se que a maior parte das áreas estudadas (75\%) apresenta entre 10 e 20 espécies arbóreas, demonstrando que a regeneração é de baixa diversidade arbórea nessa zona do Estado. 


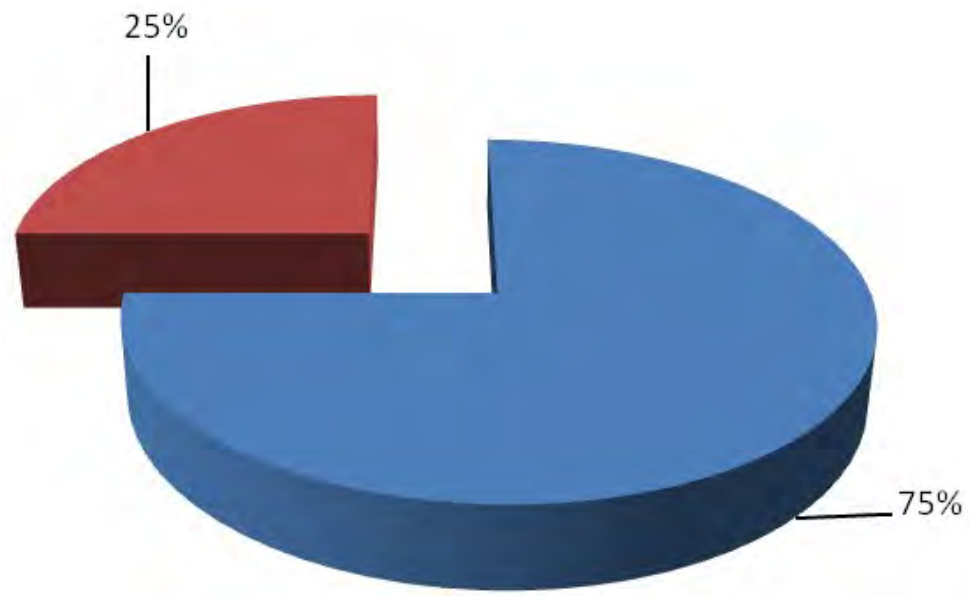

E entre 10 e 20 spp mais que 20 spp.

Figura 28 - Riqueza de espécies na zona Extremo Norte

A altura média do dossel das áreas visitadas foi de 7 metros, não tendo sido observadas espécies epífitas.

Em relação ao grupo ecológico das espécies encontradas, observa-se na Figura 29 que os grupos das pioneiras e secundárias iniciais foram os mais frequentes.

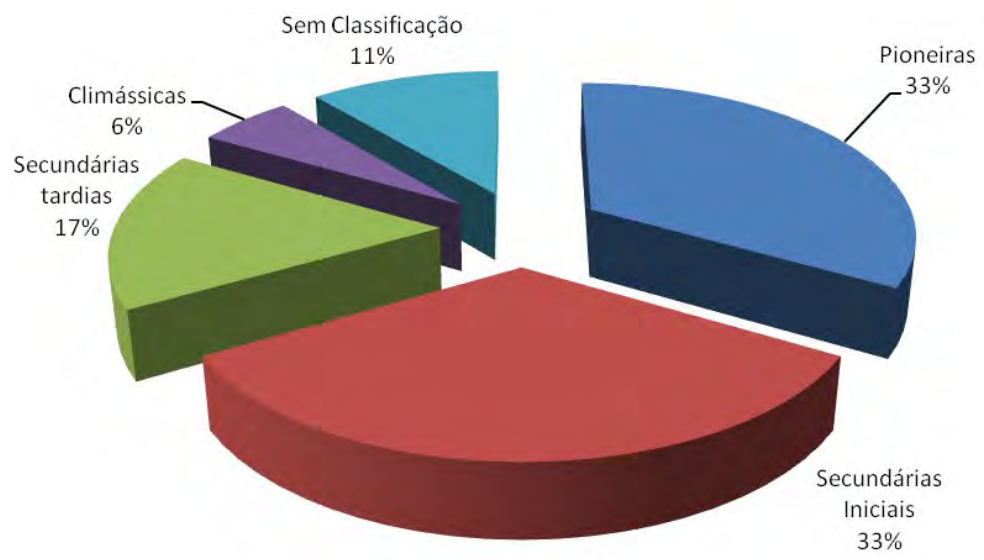

Figura 29 - Grupos ecológicos das espécies encontradas na zona Extremo Norte 
A maior parte (53\%) das espécies encontradas apresenta síndrome de dispersão zoocórica, seguida da anemocoria, com 42\% (Figura 30).
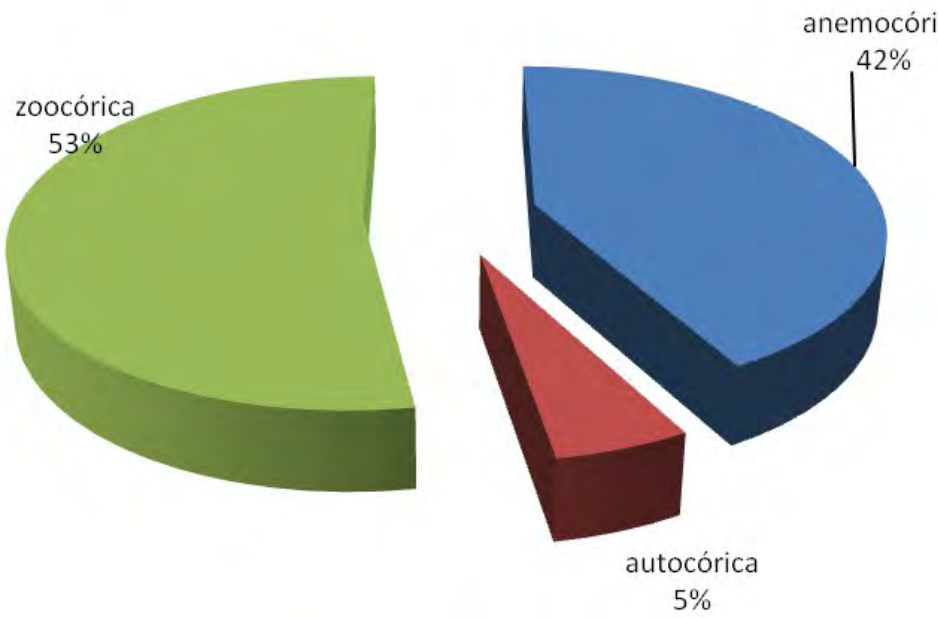

Figura 30 - Síndromes de dispersão das espécies encontradas nas áreas regeneradas da zona Extremo Norte

\subsubsection{Zona Noroeste}

Nessa zona, foram identificadas 41 espécies arbóreas nativas. As espécies observadas no maior número de áreas foram: Anadenanthera colubrina (Vell.) Brenan (Angico), encontrada em todas as áreas; Cecropia pachystachya Trécul. (Embaúba) e Sparattosperma leucanthum (Vell.) K. Schum. (Cinco-folhas), encontradas em 57\% das áreas.

Nas áreas visitadas, 8 espécies apresentaram-se fisionomicamente dominantes, sendo que Anadenanthera colubrina (Vell.) Brenan (Angico) foi considerada dominante em $50 \%$ das áreas.

Em relação à riqueza de espécies (Figura 31), pode-se observar que a maior parte das áreas estudadas (64\%) apresenta mais que 20 espécies arbóreas, demonstrando que a regeneração está contribuindo para a manutenção da biodiversidade local.

A altura média do dossel das áreas visitadas foi de 7,5 metros e não foram observadas espécies epífitas.

Em relação ao grupo ecológico das espécies encontradas, observa-se na Figura 32 que os grupos das secundárias iniciais e das pioneiras foram os mais frequentes.

A maior parte (55\%) das espécies encontradas apresenta síndrome de dispersão zoocórica, seguida da anemocoria, com 35\% (Figura 33). 


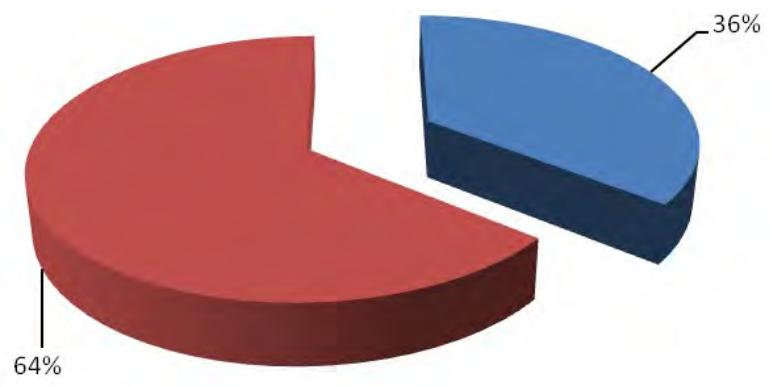

Entre 10 e 20 spp mais que 20 spp.

Figura 31 - Riqueza de espécies na zona Noroeste

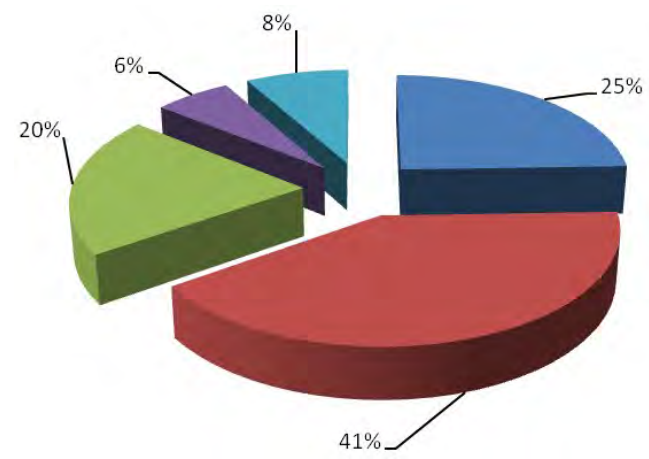

- Pioneiras

- Secundárias Iniciais

- Secundárias tardias

- Climássicas

- Sem Classificação

Figura 32 - Grupos ecológicos das espécies encontradas na zona Noroeste

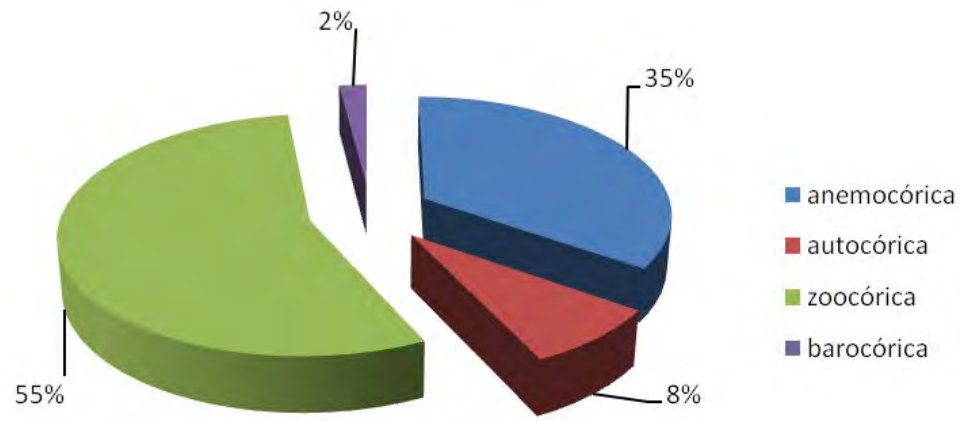

Figura 33 - Síndromes de dispersão das espécies encontradas na zona Noroeste 


\subsubsection{Zona Tabuleiro Norte}

Nessa zona, foram identificadas 47 espécies arbóreas nativas. As espécies observadas no maior número de áreas foram Protium heptaphyllum (Aubl.) Marchand (Almescla) e Xylopia sericea A.St.-Hil. (Pindaíba), encontradas em $60 \%$ das áreas.

Nas áreas visitadas, nove espécies apresentaram-se fisionomicamente dominantes, sendo que Xylopia sericea A. St.-Hil. (Pindaíba) foi considerada dominante em $30 \%$ das áreas.

Em relação à riqueza de espécies (Figura 34), observa-se que a maior parte das áreas estudadas (70\%) apresenta mais que 20 espécies arbóreas, demonstrando que a regeneração está contribuindo para a manutenção da biodiversidade local.

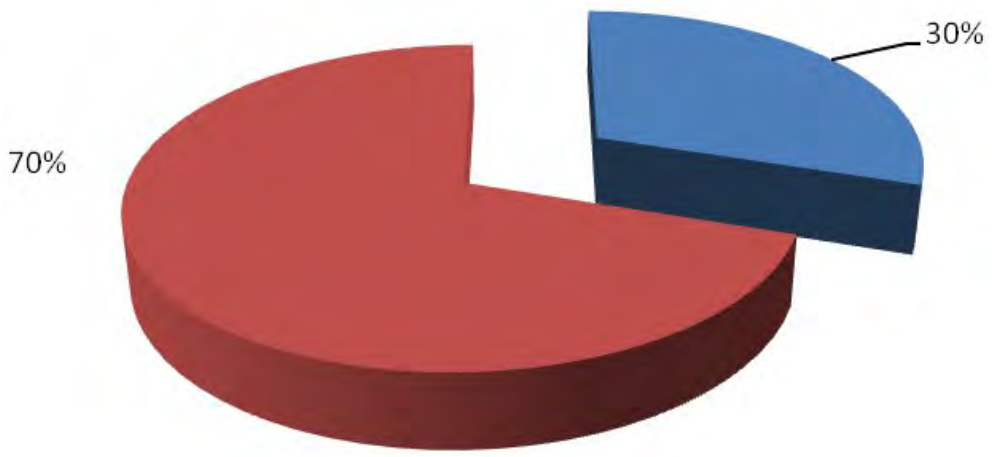

- entre 10 e 20 spp mais que 20 spp.

Figura 34 - Riqueza de espécies na zona Tabuleiro Norte

A altura média do dossel das áreas visitadas foi de 6,95 metros e foram observadas espécies epífitas em duas dessas áreas.

Em relação ao grupo ecológico das espécies encontradas, pode-se observar na Figura 35 que os grupos das secundárias iniciais e pioneiras foram os mais frequentes.

A maior parte (64\%) das espécies encontradas apresenta síndrome de dispersão zoocórica, seguida da anemocoria, com 34\% (Figura 36). 


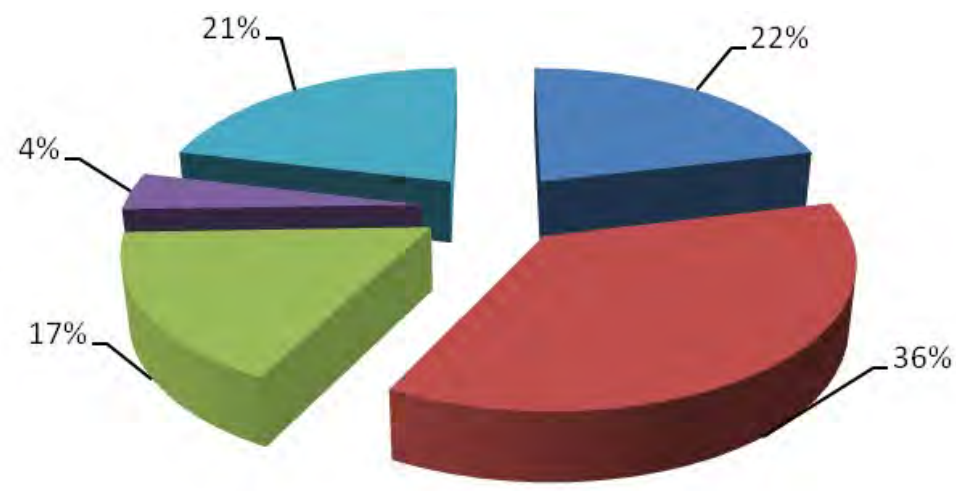

- Pioneiras

- Secundárias Iniciais

- Climássicas

- Sem Classificação

Figura 35 - Grupos ecológicos das espécies encontradas na zona Tabuleiro Norte

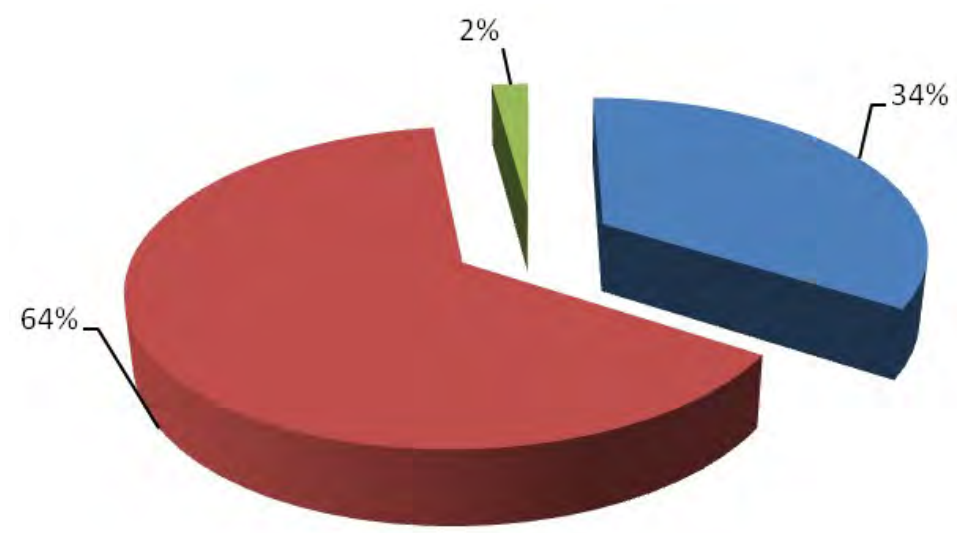

Eanemocórica zoocórica barocórica

Figura 36 - Síndromes de dispersão das espécies encontradas na zona Tabuleiro Norte

\subsubsection{Zona Litoral Norte}

Nessa zona, foram identificadas 12 espécies arbóreas nativas. Cecropia pachystachya Trécul. (Embaúba), Genipa americana L. (Genipapo) e 
Pera glabrata (Schott) Baill. (Cinta-larga) foram encontradas em todas as áreas visitadas; e Genipa americana L. (Genipapo) e Pera glabrata (Schott) Baill. (Cinta-larga) foram consideradas fisionomicamente dominantes em $50 \%$ das áreas visitadas.

Em relação à riqueza de espécies, todas as áreas visitadas apresentam mais que 20 espécies arbóreas, demonstrando que a regeneração está contribuindo para a manutenção da biodiversidade local dessa zona.

A altura média do dossel das duas áreas estudadas foi de 8 metros e foram observadas espécies epífitas.

Em relação ao grupo ecológico das espécies encontradas, observa-se na Figura 37 que os grupos das secundárias iniciais e das secundárias tardias foram os mais frequentes.
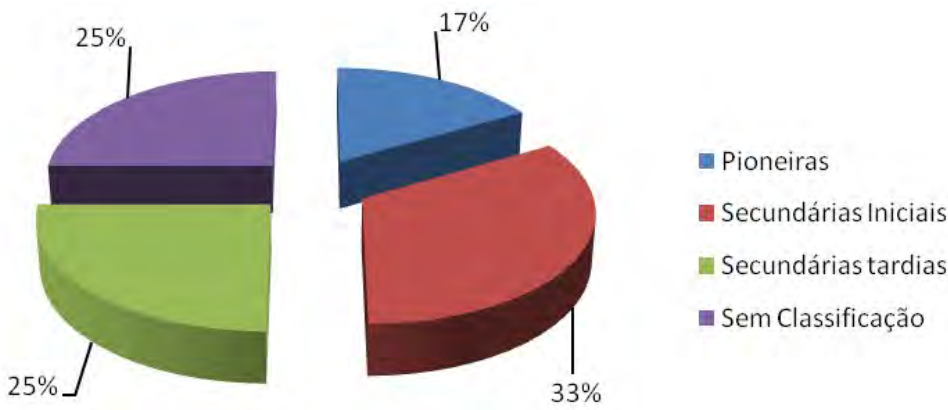

Figura 37 - Grupos ecológicos das espécies encontradas na zona Litoral Norte

A maior parte (67\%) das espécies encontradas apresenta síndrome de dispersão zoocórica, seguida da anemocoria, com 33\% (Figura 38).

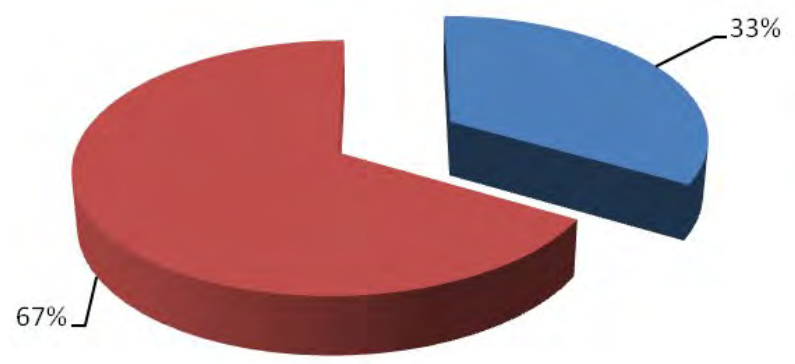

anemocoria

zoocoria

Figura 38 - Síndromes de dispersão das espécies encontradas na zona Litoral Norte 


\subsubsection{Zona Extremo Oeste Seco}

Nessa zona, foram identificadas 15 espécies arbóreas nativas. A espécie observada no maior número de áreas foi Myracrodruon urundeuva Allemão (Aroeira-do-sertão), encontrada em todas as áreas visitadas e também se apresentando fisionomicamente dominante (formando adensamentos monodominantes).

Das áreas visitadas, $66 \%$ possuem menos que 10 espécies arbóreas e $33 \%$, entre 10 e 20 espécies, demonstrando a baixa riqueza e o padrão monodominante de Myracrodruon urundeuva Allemão (Aroeira-do-sertão) nessa zona.

A altura média do dossel das áreas visitadas foi de 7 metros e não foram observadas espécies epífitas.

Em relação aos grupos ecológicos das espécies encontradas, pode-se observar na Figura 39 que os grupos das secundárias iniciais e das pioneiras foram os mais frequentes.

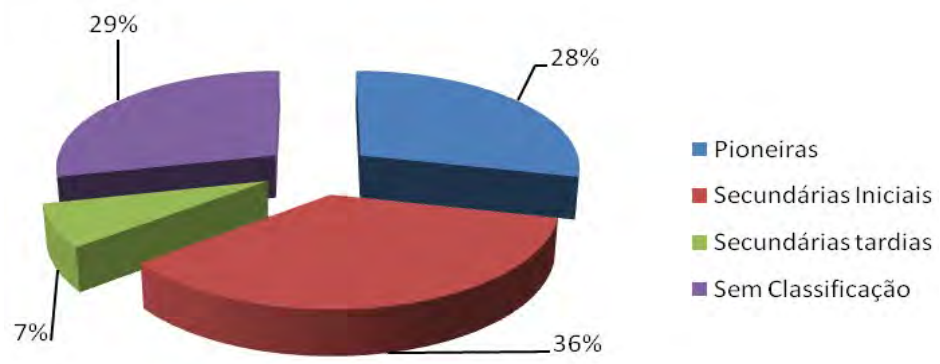

Figura 39 - Grupos ecológicos das espécies encontradas na zona Extremo Oeste Seco

Metade das espécies encontradas nessa região possui síndrome de dispersão zoocórica e a outra metade, anemocórica (Figura 40).
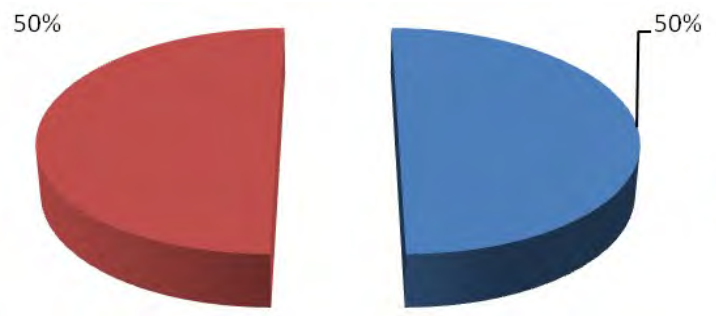

anemocórica

zoocórica

Figura 40 - Síndromes de dispersão das espécies encontradas na zona Extremo Oeste Seco 


\subsubsection{Zona Central Serrana}

Nessa zona, foram identificadas 41 espécies arbóreas nativas. As espécies observadas no maior número de áreas foram: Piptadenia gonoacantha (Mart.) J. F. Macbr. (Pau-jacaré), em 71\% das áreas; Cecropia pachystachya Trécul. (embaúba), em 64\% das áreas; e Aegiphila sellowiana Cham. (Mululo), em 50\% das áreas. Nas áreas visitadas, Piptadenia gonoacantha (Mart.) J. F. Macbr. (Pau-jacaré) foi considerada dominante em 57\% das áreas. Já Anadenanthera colubrina (Vell.) Brenan (Angico) e Gochnatia polymorpha (Less.) (Camará) foram consideradas dominantes em 7\% das áreas.

Em relação à riqueza de espécies (Figura 41), observa-se que a maior parte das áreas estudadas (71\%) apresenta mais que 20 espécies arbóreas, demonstrando que a regeneração está contribuindo para a manutenção da biodiversidade local dessa zona.

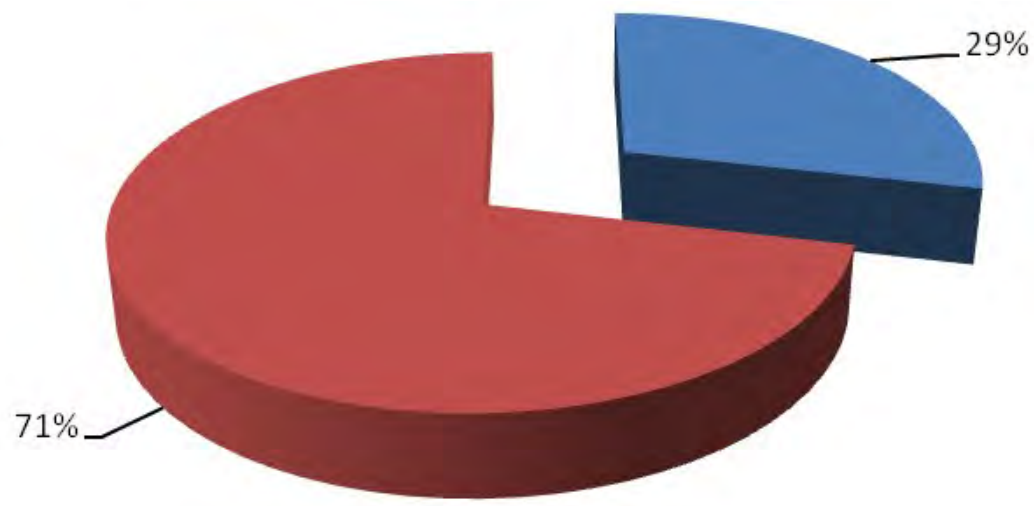

entre 10 e 20 spp mais que 20 spp.

Figura 41 - Riqueza de espécies na zona Central Serrana

A altura média do dossel das áreas visitadas foi de 7,5 metros e foram observadas espécies epífitas em $14 \%$ das áreas.

Em relação ao grupo ecológico das espécies encontradas, observou-se que os grupos das secundárias iniciais e das pioneiras foram os mais frequentes (Figura 42).

A maior parte (66\%) das espécies encontradas apresenta síndrome de dispersão zoocórica, seguida da anemocoria, com 27\% (Figura 43). 


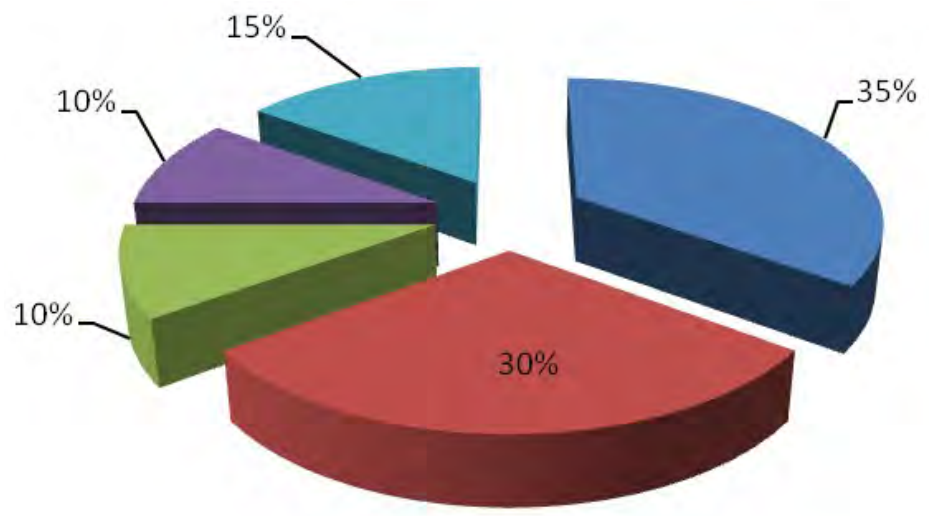

$\begin{array}{ll}\text { - Pioneiras } & \text { Secundárias Iniciais } \\ \text { Climássicas } & \text { Secundáriastardias }\end{array}$

Figura 42 - Grupos ecológicos das espécies encontradas na zona Central Serrana

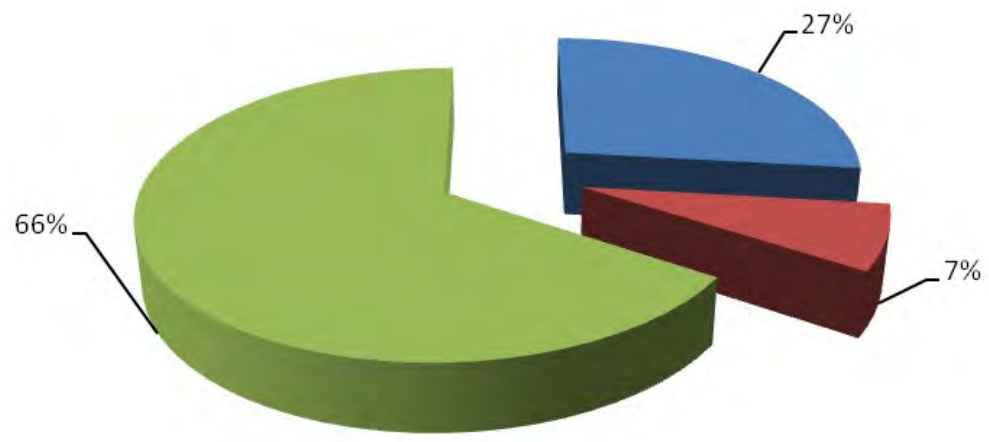

चanemocórica = autocórica zoocórica

Figura 43 - Síndromes de dispersão das espécies encontradas na zona Central Serrana

\subsubsection{Zona Transição Metropolitana/Central Serrana}

Nessa zona, foram identificadas 23 espécies arbóreas nativas. As espécies observadas no maior número de áreas foram Dalbergia nigra 
(Vell.) Allemao ex Benth. (Jacarandá), Gochnatia polymorpha (Less.) Cabrera (Camará), Inga edulis Mart. (Ingá) e Xylopia sericea A. St.-Hil. (Pindaíba), todas presentes em $66 \%$ das áreas. Nas áreas visitadas, Gochnatia polymorpha (Less.) (Camará) foi considerada dominante em alguns locais.

Em relação à riqueza de espécies (Figura 44), observou-se que a maior parte das áreas estudadas (88\%) apresenta mais que 20 espécies arbóreas, demonstrando que a regeneração está contribuindo para a manutenção da biodiversidade local.

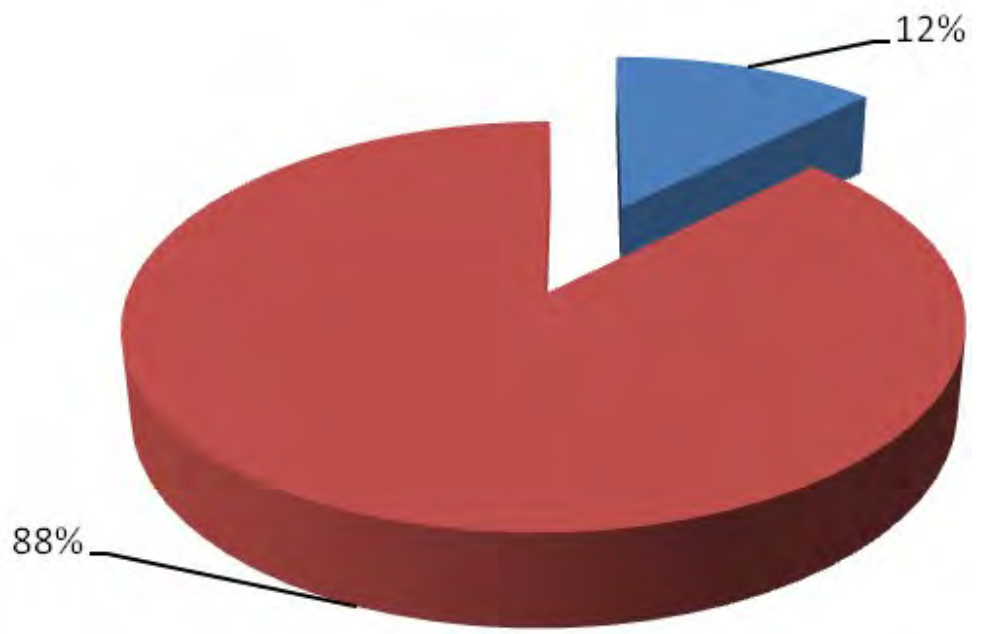

entre 10 e 20 spp mais que 20 spp.

Figura 44 - Riqueza de espécies na zona Transição

Metropolitana/Central Serrana

A altura média do dossel das áreas visitadas foi de 7 metros e foram observadas espécies epífitas em 16\% dessas áreas.

Em relação ao grupo ecológico das espécies encontradas, constataram-se que os grupos das secundárias iniciais e das pioneiras foram os mais frequentes (Figura 45).

A maior parte (59\%) das espécies encontradas apresenta síndrome de dispersão zoocórica, seguida da anemocoria, com 27\% (Figura 46). 


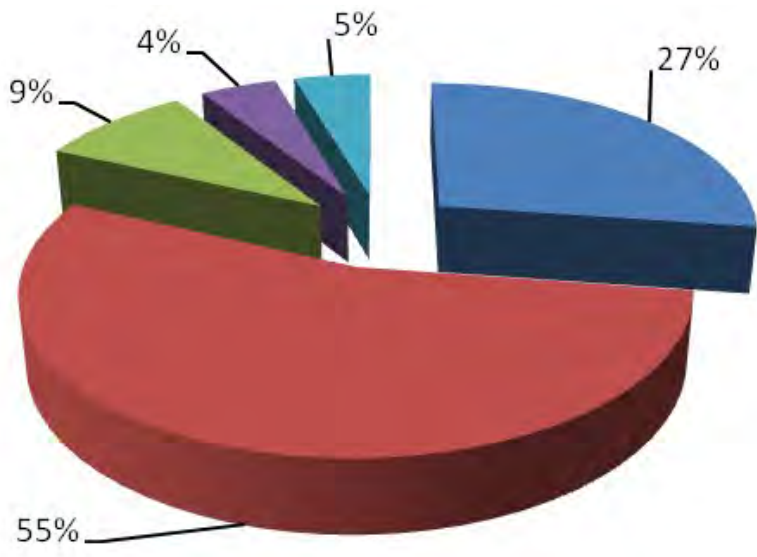

- Pioneiras

- Climássicas
- Secundárias Iniciais

- Sem Classificação

Figura 45 - Grupos ecológicos das espécies encontradas na zona Transição Metropolitana/Central Serrana

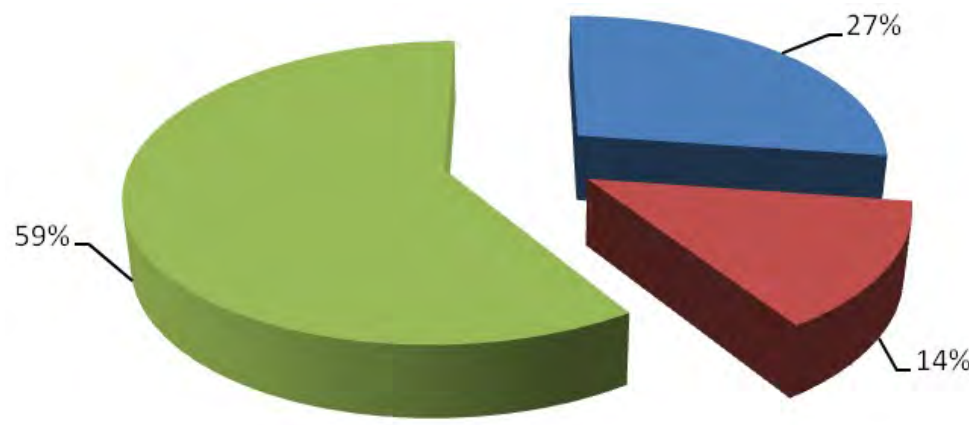

anemocórica autocórica zoocórica

Figura 46 - Síndromes de dispersão das espécies encontradas na zona Transição Metropolitana/Central Serrana

\subsubsection{Zona Metropolitana}

Nessa zona, foram identificadas 14 espécies arbóreas nativas. A altura do dossel foi de 6 metros e observou-se apenas uma espécie epífita (Tillandsia stricta Sol. ex Sims). 
Em relação ao grupo ecológico das espécies encontradas, observou-se que metade delas pertence ao grupo das pioneiras (Figura 47). A maior parte (64\%) das espécies encontradas apresenta síndrome de dispersão zoocórica (Figura 48).
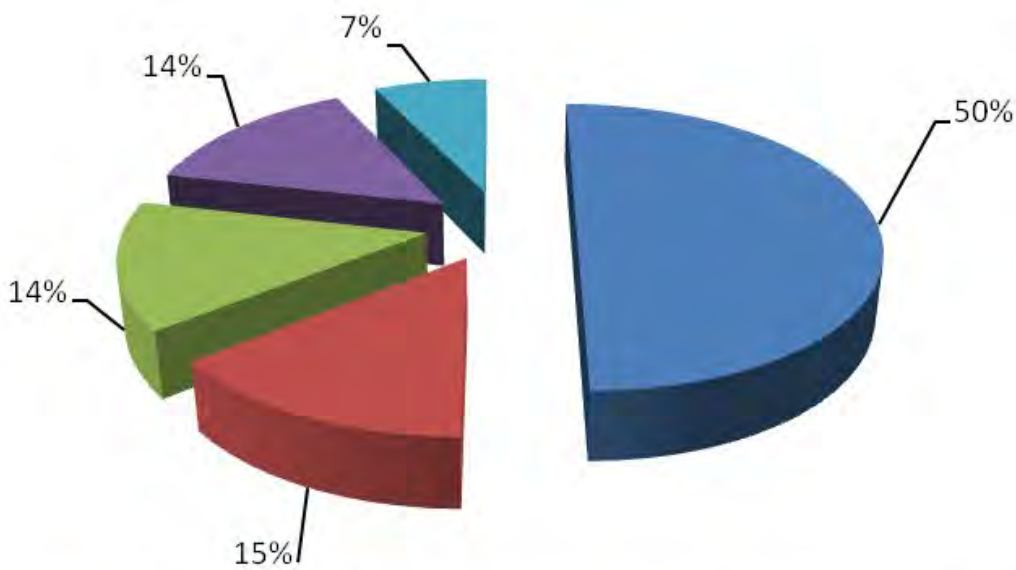

a Pioneiras

- Secundárias Iniciais

Climássicas

- Sem Classificação

Figura 47 - Grupos ecológicos das espécies encontradas na zona Metropolitana

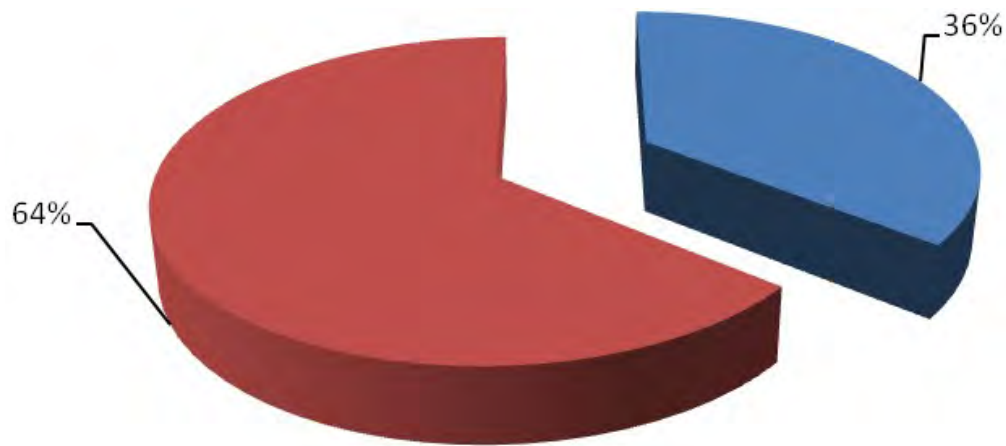

घanemocórica zoocórica

Figura 48 - Síndromes de dispersão das espécies encontradas na zona Metropolitana 


\subsubsection{Zona Tabuleiro Sul/Extremo Sul Baixo}

Nessa zona, foram identificadas 18 espécies arbóreas nativas, sendo Anadenanthera colubrina (Vell.) Brenan (Angico) considerada dominante em 33\% das áreas e Gochnatia polymorpha (Less.) Cabrera (Camará) em 66\% das áreas.

A altura média do dossel foi de 8 metros e não foram observadas espécies epífitas.

Em relação ao grupo ecológico das espécies encontradas, os grupos das secundárias iniciais e das pioneiras foram os mais frequentes (Figura 49). A maior parte (61\%) das espécies encontradas apresenta síndrome de dispersão zoocórica (Figura 50).

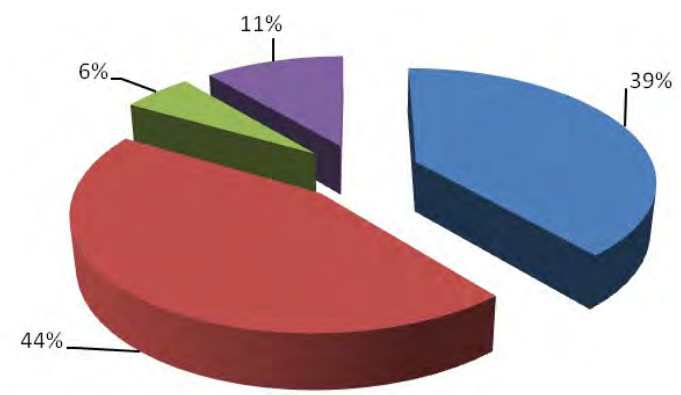

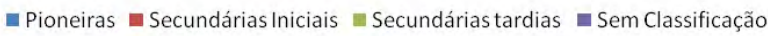

Figura 49 - Grupos ecológicos das espécies encontradas na zona Tabuleiro Sul/Extremo Sul Baixo

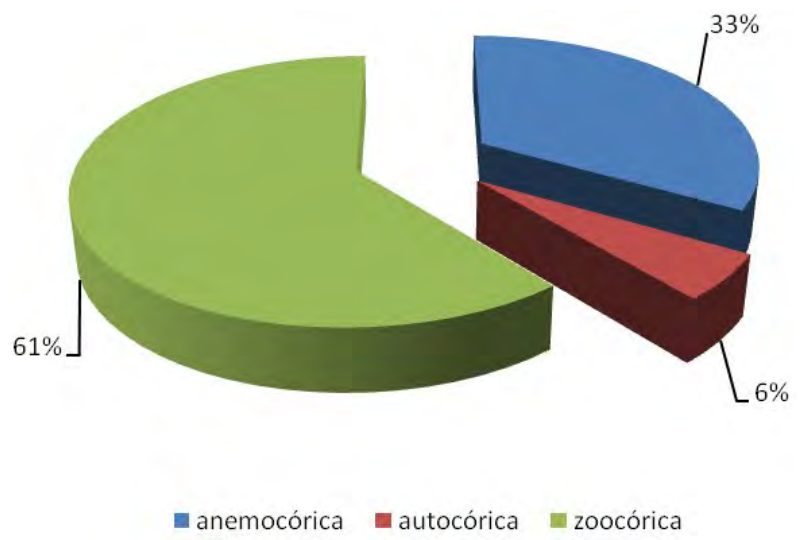

Figura 50 - Síndromes de dispersão das espécies encontradas na zona Tabuleiro Sul/Extremo Sul Baixo 


\subsubsection{Zona Central Sul}

Nessa zona, foram identificadas 8 espécies arbóreas nativas, sendo Anadenanthera colubrina (Vell.) Brenan (Angico) considerada dominante. A altura do dossel foi de 8 metros e não foram observadas espécies epífitas.

Em relação ao grupo ecológico das espécies encontradas, observou-se que os grupos das secundárias iniciais e das tardias foram os mais frequentes (Figura 51). A maior parte (57\%) das espécies encontradas apresenta síndrome de dispersão anemocórica (Figura 52).

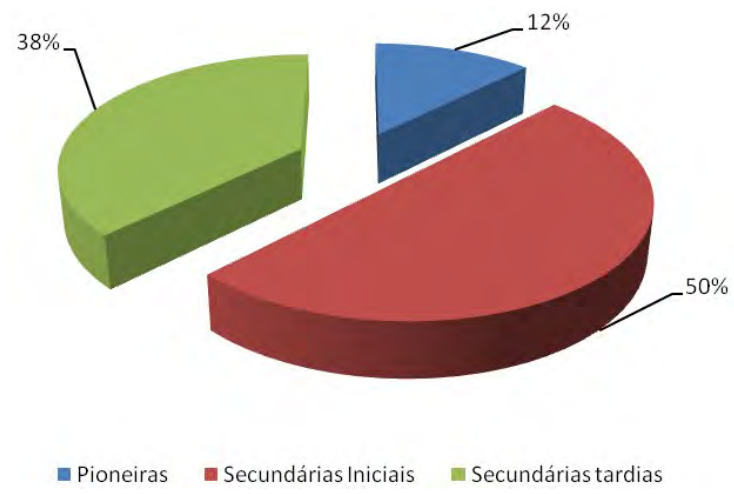

Figura 51 - Grupos ecológicos das espécies encontradas na zona Central Sul

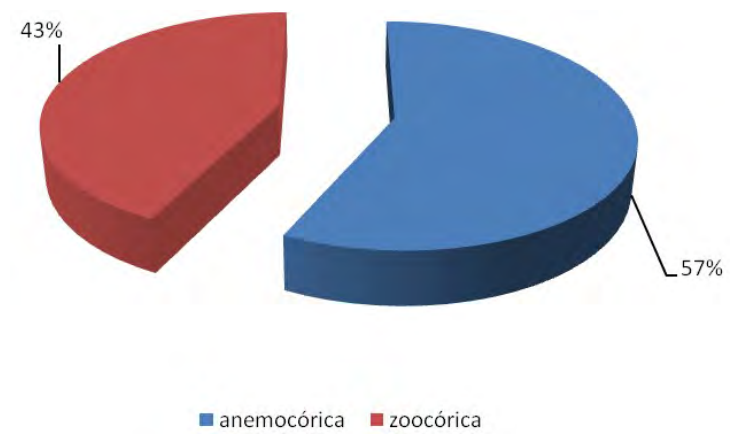

Figura 52 - Síndromes de dispersão das espécies encontradas na zona Central Sul

\subsubsection{Zona Extremo Sul Acidentado}

Nessa região, foram identificadas 11 espécies arbóreas nativas. A espécie que foi observada no maior número de áreas foi Piptadenia gonoacantha (Mart.) J. F. (Pau-jacaré), encontrada em todas as áreas amostradas. Essa espécie também foi considerada dominante em $50 \%$ das áreas 
visitadas, junto com Anadenanthera colubrina (Vell.) Brenan (Angico). Já as embaúbas Cecropia pachystachya Trécul. e Cecropia hololeuca Miq. foram consideradas dominantes em $25 \%$ das áreas.

Em relação à riqueza de espécies (Figura 53), observou-se que a maior parte das áreas estudadas (75\%) apresenta entre 10 e 20 espécies.

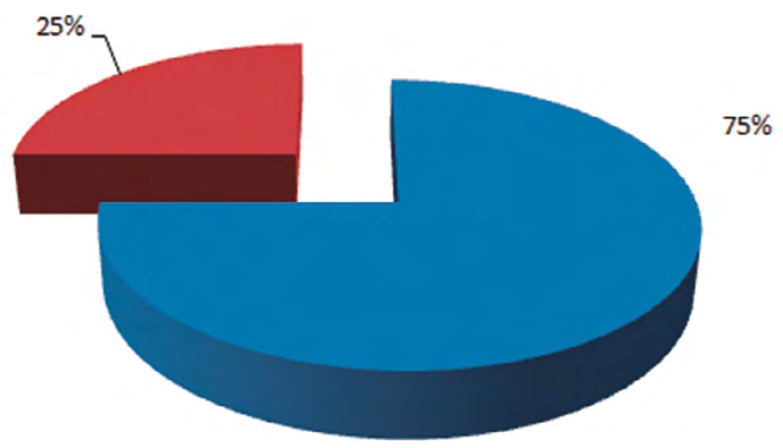

mentre 10 e $20 \mathrm{spp}$ mais que 20 spp.

Figura 53 - Riqueza de espécies na zona Extremo Sul Acidentado

A altura média do dossel das áreas visitadas foi de 8,5 metros e não foram observadas espécies epífitas.

Em relação ao grupo ecológico das espécies encontradas, os grupos das pioneiras e das secundárias iniciais foram os mais frequentes (Figura 54).

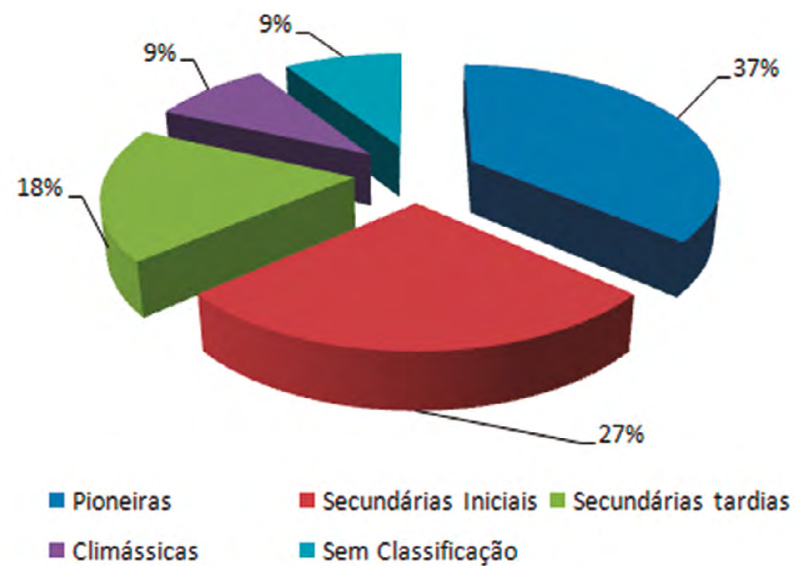

Figura 54 - Grupos ecológicos das espécies encontradas na zona Extremo Sul Acidentado 
As síndromes de dispersão com maior frequência foram anemocoria e zoocoria (Figura 55).

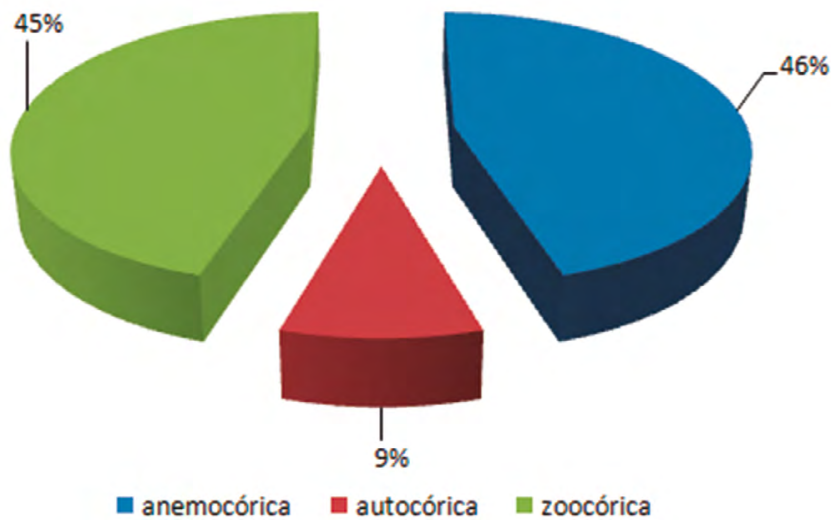

Figura 55 - Síndromes de dispersão das espécies encontradas na zona Extremo Sul Acidentado

\subsubsection{Zona Polo Caparaó}

Nessa zona, foram identificadas 11 espécies arbóreas nativas. A altura do dossel foi de 7 metros e não foram observadas espécies epífitas.

Em relação ao grupo ecológico das espécies encontradas, observou-se que $45 \%$ delas pertencem ao grupo das pioneiras (Figura 56). A maior parte (64\%) das espécies encontradas apresenta síndrome de dispersão zoocórica (Figura 57).

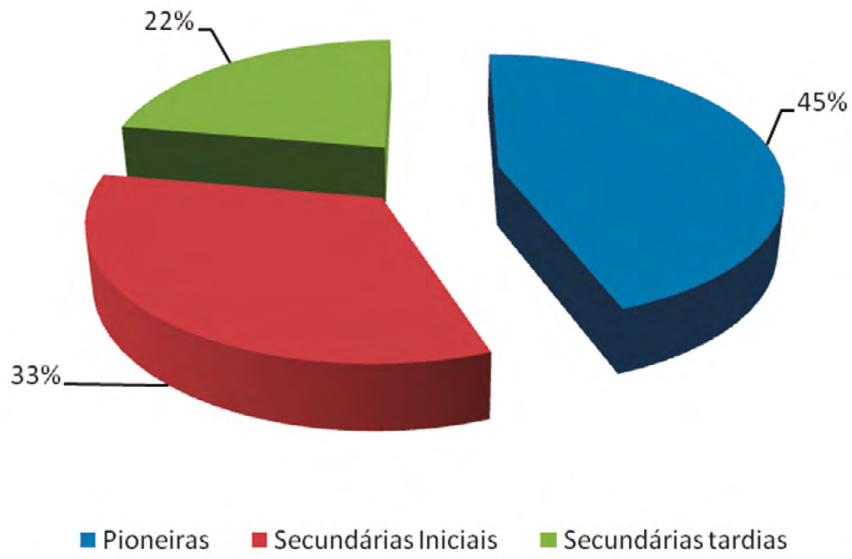

Figura 56 - Grupos ecológicos das espécies encontradas na zona Polo Caparaó 


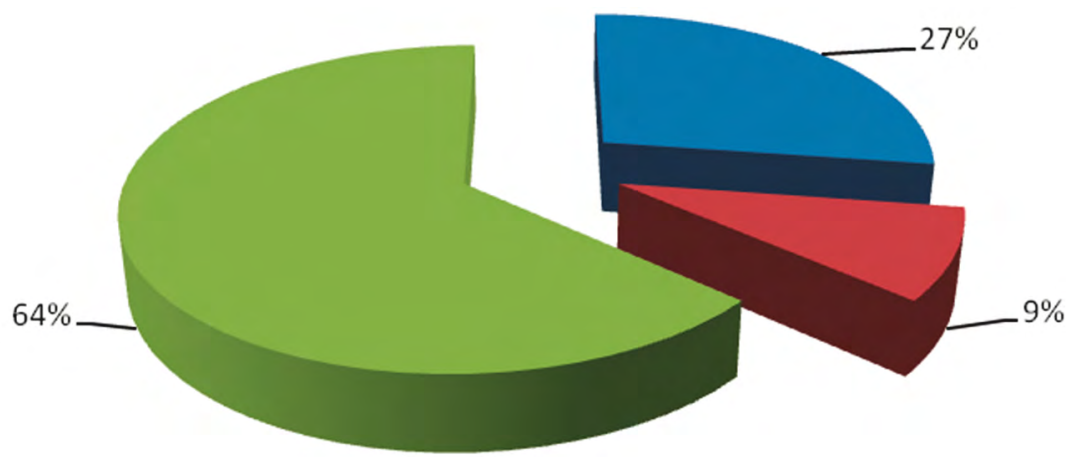

anemocórica $\quad$ autocórica $\quad$ zoocórica

Figura 57 - Síndromes de dispersão das espécies encontradas na zona Polo Caparaó 


\section{6 \\ Principais constatações, conclusões e recomendações}

- No Estado do Espírito Santo, $60,88 \%$ de sua área total, o que equivale a 2.804.431 hectares, apresentam um alto potencial de regeneração natural de florestas, não sendo necessário, na maior parte dessas áreas, o plantio de mudas para a restauração florestal.

- A zona Central Serrana foi a que apresentou maior potencial de regeneração natural, com cerca de $80 \%$ de sua área apresentando potencial de receber propágulos, enquanto nas zonas Extremo Norte e Tabuleiro Sul/Extremo Sul Baixo foram encontrados os menores potenciais de regeneração natural, com 37,7 e $35 \%$ de sua área, respectivamente, como potencial de receber propágulos.

- Do total de 12 (doze) zonas naturais delimitadas no Estado do Espírito Santo, três foram consideradas com alto potencial de regeneração natural; duas com transição médio/alto potencial de regeneração natural; quatro com médio potencial de regeneração natural e três com baixo potencial de regeneração natural.

- Nos últimos 33 anos, 18.979 florestas se regeneraram naturalmente no Espírito Santo, ocupando uma área de 106.554,87 hectares.

- Existem 37.708 fragmentos florestais potenciais fornecedores de propágulos (florestas matrizes) para a regeneração natural, ocupando uma área de 628.083,12 hectares, o que corresponde a 13,64\% da área total do Espírito Santo.

- As zonas com maior índice pluviométrico apresentaram, de forma geral, maior velocidade na regeneração natural.

- Há uma forte correlação positiva entre o número de florestas fornecedoras de propágulos (florestas matrizes) e o número de florestas regeneradas; e entre a proximidade e o tamanho da floresta matriz e a velocidade da regeneração natural e sua 
diversidade; em contrapartida, quando na área há a ocorrência de espécies-problema, a velocidade da regeneração natural é reduzida.

- As florestas regeneradas alcançaram o estágio médio de regeneração em tempos diferentes, variando de 12 anos até 34 anos; as que apresentaram maiores velocidades estão nas zonas Transição Metropolitana/Central Serrana, Central Serrana e Extremo Sul Acidentado.

- As menores distâncias entre floresta matriz e floresta regenerada são as das zonas Central Serrana (250 metros) e Transição Metropolitana/Central Serrana (270 metros); e a maior distância foi encontrada na zona Extremo Norte (500 metros).

- As zonas Central Serrana e Transição Metropolitana/Central Serrana apresentaram as maiores áreas (ha) de floresta matriz/ $\mathrm{km}^{2}$, com valores de 24,03 ha e 24,06 ha, respectivamente; e a zona Extremo Norte apresentou a menor, com valor de 4,54 ha.

- A zona Tabuleiro Norte apresentou as florestas regeneradas com maiores tamanhos médios, perfazendo 12,3 ha. Ressalta-se que essa zona também apresentou florestas matrizes de grandes dimensões médias (33,95 ha).

- O maior número de florestas regeneradas $/ \mathrm{km}^{2}$ está presente nas zonas Central Serrana e Transição Metropolitana/Central Serrana. Em contrapartida, as zonas Extremo Norte e Litoral Norte apresentaram os menores números de florestas regeneradas $/ \mathrm{km}^{2}$.

- A zona Tabuleiro Norte destacou-se em relação ao parâmetro área de floresta regenerada $/ \mathrm{km}^{2}$, correspondendo a $4,04 \%$ de sua área total.

- É necessária uma revisão da legislação estadual para adequar os parâmetros de enquadramento dos estágios sucessionais à realidade florestal.

- Os principais fatores que influenciaram na regeneração natural foram: proximidade das florestas fornecedoras de propágulos vegetativos (florestas matrizes), estrutura e funcionalidade das florestas matrizes, presença de espécies-problema e condições pedoclimáticas.

- As espécies presentes no maior número de áreas foram Cecropia pachystachya Trécul. (Embaúba), Anadenanthera colubrina (Vell.) Brenan (Angico), Sparattosperma leucanthum (Vell.) K. Schum. (Cinco-folhas), Piptadenia gonoacantha (Mart.) J. F. Macbr. (Pau-jacaré) e Aegiphila sellowiana Cham. (Mululo). 
- Nas áreas visitadas, 21 espécies foram consideradas fisionomicamente dominantes, sendo as mais representativas Anadenanthera colubrina (Vell.) Brenan (Angico), Piptadenia gonoacantha (Mart.) J. F. Macbr. (Pau-jacaré), Myracrodrum urundeuva (Aroeira-dosertão) e Gochnatia polymorpha (Camará).

- Recomendam-se como estratégias de restauração florestal para o Estado do Espírito Santo, ressalvadas as particularidades locais: a) para as zonas com alto e transição médio/alto potencial de regeneração natural, o simples isolamento das áreas dos fatores de degradação (fogo e gado); b) para as zonas com médio potencial de regeneração natural, o isolamento dos fatores de degradação e a adoção de técnicas de nucleação (transposição de serapilheira/solo, semeadura direta etc.); c) para as áreas com baixo potencial de regeneração natural, a adoção de técnicas de nucleação (transposição de serapilheira/solo, semeadura direta etc.) em conjunto com o plantio de mudas, seguindo modelos ecológicos de baixo custo.

\section{Referências}

ALMEIDA JUNIOR, H. C. Evolução da fragmentação de mata no município de Santa Maria de Jetibá. 2006. Monografia (Conclusão do Curso em Geografia) - Universidade Federal do Espírito Santo, Vitória: 2006.

BELLOTO, A.; VIANI, R. A. G.; NAVE, A. G.; GANDOLFI, S.; RODRIGUES, R. R. Monitoramento das áreas restauradas como ferramenta para a avaliação da efetividade das ações de restauração e para redefinição metodológica. In: RODRIGUES, R. R.; BRANCALION, P. H. S.; ISERNHAGEN, I. (org.). Pacto para a restauração ecológica da Mata Atlântica: referencial dos conceitos e ações de restauração florestal. São Paulo: Instituto BioAtlântica, 2009. v. 1. p. 128-146.

BRANCALION, P. H. S.; VIANI, R. A. G.; RODRIGUES, R. R.; GANDOLFI, S. Avaliação e monitoramento de áreas em processo de restauração: restauração ecológica de ecossistemas degradados. Viçosa, MG: Ed. UFV, 2012. p. 262-293.

CAMPELLO, E. F. C. Sucessão vegetal na recuperação de áreas degradadas. In: DIAS, L.E.; MELLO, J.W.V. (ed.). Recuperação de áreas degradadas. Viçosa, MG: UFV, Departamento de Solos; Sociedade Brasileira de Recuperação de Áreas Degradadas, 1998. p. 183-202. 
CARPANEZZI, A. A.; COSTA, L. G. S.; KAGEYAMA, P. Y.; CASTRO, C. F. A. Espécies pioneiras para recuperação de áreas degradadas: observações de laboratórios naturais. In: Congresso Florestal Brasileiro, 6으, Campos do Jordão, 1990. Anais, São Paulo, Sociedade Brasileira de Silvicultura, 1990. p. 216-221.

CARVALHO, J. O. P. Análise estrutural da regeneração natural em floresta tropical densa na região do Tapajós no Estado do Pará. Curitiba: UFPR, 1982. 128p. Dissertação (Mestrado em Ciências Florestais) - Universidade Federal do Paraná, 1982.

CARVALHO, P. E. R. Espécies arbóreas brasileiras. Brasília: Embrapa Informação Tecnológica, 2003.

CLARK, C. J.; POULSEN, J. R. The role of arboreal sees dispersal groups in the seed rain of a Lowland Tropical Forest. Biotropica, v. 33, p. 606-620, 2001.

COSTA, L. G. S.; PINA-RODRIGUES, F. C. M.; JESUS, R. Grupos ecológicos e a dispersão de sementes de espécies arbóreas em trecho de floresta tropical na Reserva Florestal de Linhares (ES). In: Congresso Nacional sobre Essências Nativas: conservação da biodiversidade. Anais, São Paulo, Instituto Florestal, 1992. p. 19-20.

CURTIS, J. T.; McINTOSH, R. P. Na upland forest continuum in the prairie forest border region of Wisconsin. Ecology, v. 32, p. 476-496, 1951.

DURIGAN, G.; ENGEL, V. L. Restauração de ecossistema no Brasil: onde estamos e para onde queremos chegar. In: MARTINS, S.V. (ed.).

Restauração ecológica de ecossistemas degradados. Viçosa, MG: Ed. UFV, 2012. p. 41-68.

EGLER, F. E. Vegetation science concepts. 1. Initial floristic composition a factor in old-field vegetation development. Vegetatio, v. 4, p. 421-417, 1954.

FERRETTI, A. R. Modelos de plantios para a recuperação. In: GALVÃO, A. P. M.; MEDEIROS, A. C. S. (ed.). A restauração da Mata Atlântica em áreas de sua primitiva ocorrência natural. Colombo: Embrapa Floresta, 2002.p. 35-44. (Ed. Técnicos).

FINOL, U. H. Nuevos parametros a considerarse em el analisis estructural de las selvas virgines tropicales. Revista Florestal Venezuelana, v. 14, n. 21, p. 29-42, 1971.

GALINDO-GONZÁLEZ, J.; GUEVERA, S.; SOSA, V. J. Bat - and BirdGenerated seed rains at isolated trees in pastures in a tropical rainforest. Conservation Biology, v. 14, n. 6, p. 1693-1703, 2000.

GAMA, J. R. V.; BOTELHO, S. A.; BENTES-GAMA, M. de M. Composição florística e estrutural da regeneração natural de floresta secundária de várzea baixa no estuário amazônico. Revista Árvore, Viçosa, MG, v. 26, n. 5, p. 559-566, 2002. 
GENTRY, A. H. Changes in plant community diversity and floristic composition on environmental and geographical gradients. Annals of the Missouri Botanical Garden, v. 75, n. 1, p. 1-34, 1988.

GUEVARA, S.; LABORDE, J.; SANCHEZ-RIOS, G. Rain Forest regeneration beneath the canopy of fig trees isolated in pastures of Los Tuxtlas, Mexico. Biotropica, v. 36, p. 99-108, 2004.

HOLL. K. D. Factors limiting tropical rain forest regeneration in abandoned pasture: seed rain, seed germination, microclimate and soil. Biotropica, v. 31, n. 2, p. 229-242, 1999.

JESUS, R. M.; ROLIM, S. G. Experiências relevantes na restauração da Mata Atlântica. In: GALVÃO, A. P. M.; SILVA, V. P. (ed.). Restauração florestal: fundamentos e estudos de caso. Colombo: Embrapa Florestas, 2005. p. 59-86.

Jordano, P., M. Galetti, M.A: Pizo, and W.R. SIlva. 2006. Ligando Frugivoria e Dispersão de sementes à biologia da conservação. Páginas 411-436, In:Duarte, C.F., Bergallo, H.G., Dos Santos, M.A., and Va, A.E. (eds.). Biologia da conservação: essências. Editorial Rima, São Paulo, Brasil KIMMINS, J. P.; MAILLY, D. Ecological succession: processes of change in ecosystem. In: KIMMINS, J. P. (ed.). Forest Ecology. New York: Macmillan Publishing Company, 1996. p. 399-348.

KOLB, S. R. Islands of secondary vegetation in degraded pastures of Brazil: their role in reestablishing Atlantic Coastal Forest. Athens: University of Georgia. 127f. 1993. Tese (Doutorado) University of Georgia, 1993.

LOISELLE, B. A.; BLAKE, J. G. Temporal variation in birds and fruits along an elevational gradient in Costa Rica. Ecology. v. 72, p. 180-193, 1991. LORENZI, H. Árvores brasileiras: manual de identificação e cultivo de plantas arbóreas nativas do Brasil. 5. ed. Nova Odessa: Instituto Plantarum, 2008. v. 1.384 p.

MAGNAGO, L. F. S.; MARTINS, S. V.; VENKKE, T. S.; IVANAUSKAS, N. M. Os processos e estágios sucessionais da mata atlântica como referência para a restauração florestal. In: MARTINS, S. V. (ed.). Restauração ecológica de ecossistemas degradados. Viçosa, MG: Ed. UFV, 2012. p. 69-100.

MAGNAGO, L. F. S.; SIMONELLI, M.; MARTINS, S. V.; MATOS, F. A. R.; DEMUNER, V. G. Variações estruturais e características edáficas em diferentes estádios sucessionais de floresta ciliar de Tabuleiro, ES. Revista Árvore, v. 35, n. 3, p. 445-456, 2011.

MARTINS, S. V. Recuperação de áreas degradadas: ações em áreas de preservação permanente, voçorocas, taludes rodoviários e de mineração. 2. ed. Viçosa, MG: Aprenda Fácil, 2013. 207 p. 
Recuperação de matas ciliares. 2. ed. Viçosa, MG: Aprenda Fácil, 2007. 255 p.

. Restauração ecológica de ecossistemas degradados. Viçosa, MG: Ed. UFV, 2012. 293p. il. (colorido).

Soil seed bank as indicator potential in canopy gaps of a semideciduous Forest in Southeastern Brazil. In: FOURNIER, M. V. (ed.). Forest regeneration: ecology, management and economics. New York: Nova Science Publishers, 2009. p. 133-128.

MARTINS, S. V.; MIRANDA NETO, A.; RIBEIRO, T. M. Uma abordagem sobre diversidade e técnicas de restauração ecológica. In: MARTINS, S. V. (ed.). Restauração ecológica de ecossistemas degradados. Viçosa, MG: Ed. UFV, 2012. p. 17-40.

MCCLANAHAN, T. R. The effects of a seed source on primary succession in a forest ecosystem. Vegetation, v. 65, p. 175-178, 1986.

MOREIRA, J. R.; PIOVEZAN, U. Conceitos de manejo da fauna, manejo de populações problema e o exemplo da capivara. Documentos 155. Brasília: EMBRAPA Recursos Genéticos e Biotecnologia, 2005. 23p.

MORIM, M. P. Piptadenia. In: Lista de Espécies da Flora do Brasil. Rio de Janeiro: Jardim Botânico do Rio de Janeiro, 2013. Disponível em: http:// floradobrasil.jbrj.gov.br/jabot/floradobrasil/FB31387. Acesso em: 30/03/2014 NUNES, Y. R. F.; FAGUNDES, M.; ALMEIDA, H. D. S.; VELOSO, M. D. D. M. Aspectos ecológicos da aroeira (Myracrodruon urundeuva AllemãoAnacardiaceae): fenologia e germinação de sementes. Revista Árvore, v. 32, n. 2, p. 233-243, 2008.

NEPSTAD, D. C.; UHL, S.; SERRÃO, E. S. Recuperation of a degraded Amazonian landscape: forest recovery and agricultural restoration. Ambio, Sweden, 1991.

OLIVEIRA, F. P. Monodominância de aroeira: fitossociologia, relações pedológicas e distribuição espacial em Tumiritinga - MG. 2011. 79f. Dissertação (Mestrado em Solos e Nutrição de Plantas) - Universidade Federal de Viçosa, Viçosa/MG. 2011.

PARROTA, J. A. Secondary forest regeneration on degraded tropical lands: the role of plantations as "foster ecosystems". In: LEITH, H.; LOTHMANN, M. (ed.). Restoration of tropical forest ecosystems. Kluwer Academic, Netherlands, 1993. p. 63-73.

RICKLEFS, R. E. A economia da natureza. Rio de Janeiro: Guanabara Koogan, 2003.503p.

RODRIGUES R. R.; GANDOLFI S. Conceitos, tendências e ações para a recuperação de florestas ciliares. In: RODRIGUES, R. R.; LEITÃO-FILHO, H. 
F. (ed.). Matas ciliares: conservação e recuperação. São Paulo: Editora da USP/Fapesp, 2004. p. 235-247.

SAMPAIO, A. B.; HOLL, K. D.; SCARIOT, A. Does restoration enhance regeneration of seasonal deciduous forest in pastures in Central Brazil? Restoration Ecology, v. 15, n. 3, p. 462-471, 2007.

SANCHO, G.; ROQUE, N. Gochnatia in Lista de espécies da flora do Brasil. Rio de Janeiro: Jardim Botânico do Rio de Janeiro, 2013. Disponível em: http://floradobrasil.jbrj.gov.br/jabot/floradobrasil/ FB5325.

SILVA-LUZ, C. L.; PIRANI, J. R. Anacardiaceae in Lista de espécies da flora do Brasil. Rio de Janeiro: Jardim Botânico do Rio de Janeiro, 2013. Disponível em: http://floradobrasil.jbrj.gov.br/jabot/floradobrasil/ FB4394.

SILVA, J. M. C. da; UHL, C.; MURRY, G. Plant succession, landscape management, and the ecology of frugivorous birds in abandoned Amazonian pastures. Conservation Biology, v. 10, n. 2. p. 491-503, 1996. SIMONELLI, M.; MAGNAGO, L. F. S.; MARTINS, S. V. M.; MATOS, F. A. R.; DEMUNER, V. G. Composição de espécies arbóreas em três estádios sucessionais de floresta ciliar na Lagoa Jacuném, Espírito Santo, Brasil. Boletins do Museu de Biologia Mello Leitão (N. Sér.), v. 28, p. 5-19, 2010.

TABARELLI, M.; PERES, C. A. Abiotic and vertebrate seed dispersal in the Brazilian Atlantic Forest: implications for Forest regeneration.

Biological Conservation, v. 106, p. 165-176, 2002.

VIEIRA, D. L. M.; SCARIOT, A. Principles of natural regeneration of tropical dry Forests for restoration. Restoration Ecology, v. 14, n. 1, p. 11-20, 2006.

VOLPATO, G. H.; LOPES, E. V.; ANJOS, L. dos.; MARTINS, S. V. O papel ecológico das aves dispersoras de sementes na restauração ecológica. In: MARTINS, S. V. (ed.). Restauração ecológica de ecossistemas degradados. Viçosa, MG: Ed. UFV, 2012. p. 191-211.

WUNDERLE, J. M. The role of animal seed dispersal in accelerating native forest regeneration on degraded tropical lands. Forest Ecology and Management, v. 99, p. 223-235, 1997. 



\section{Anexo}

\section{Fotos}

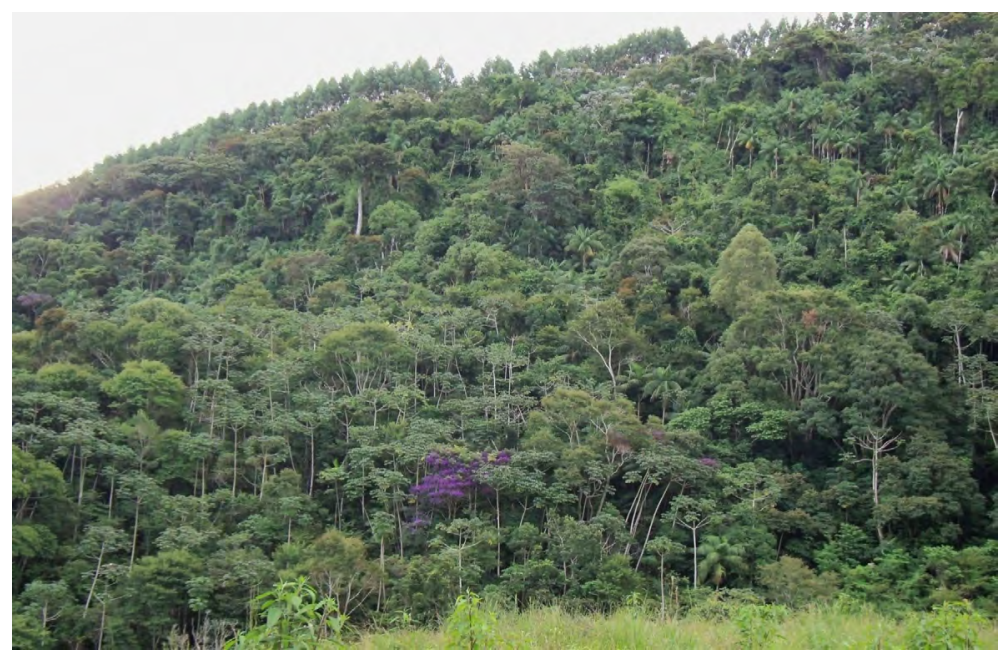

Ibitirama, ES: fragmento florestal em estágio médio de regeneração, anexo à floresta fornecedora de propágulos, com 15 anos de regeneração e ocupado anteriormente, durante mais de 20 anos, por culturas agrícolas - presença de várias espécies, destacando-se o Jacaré, a Embaúba, a palmeira Juçara e a Quaresmeira 


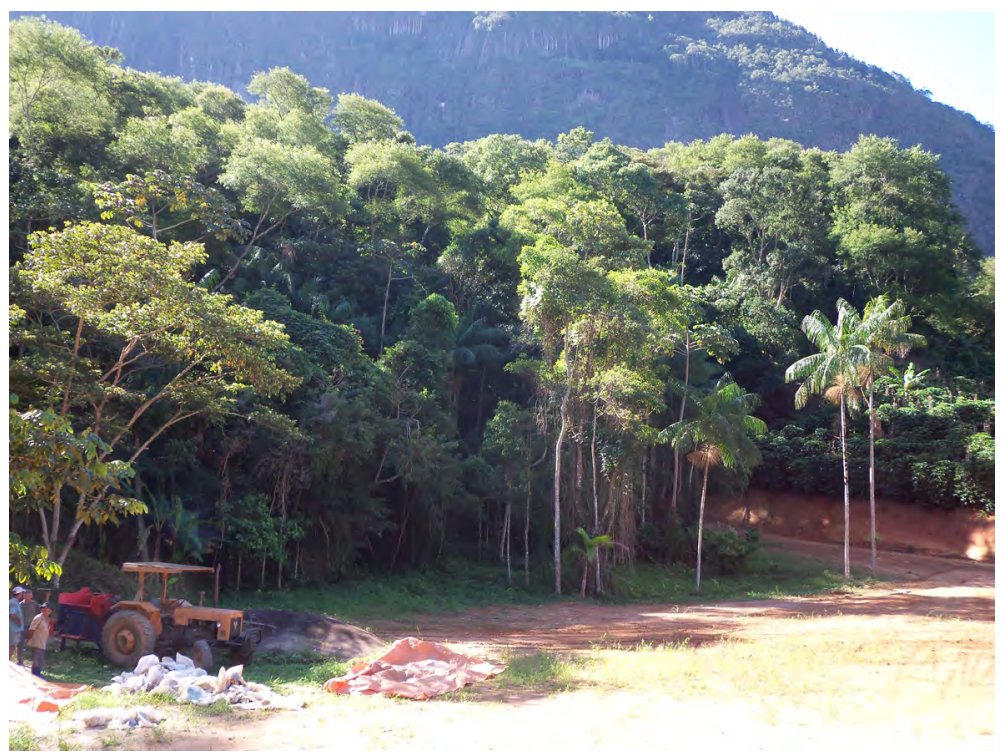

Ibitirama, ES: fragmento florestal em estágio avançado de regeneração, a 730 metros da floresta fornecedora de propágulos, com 35 anos de regeneração e ocupado anteriormente, durante mais de 20 anos, por café

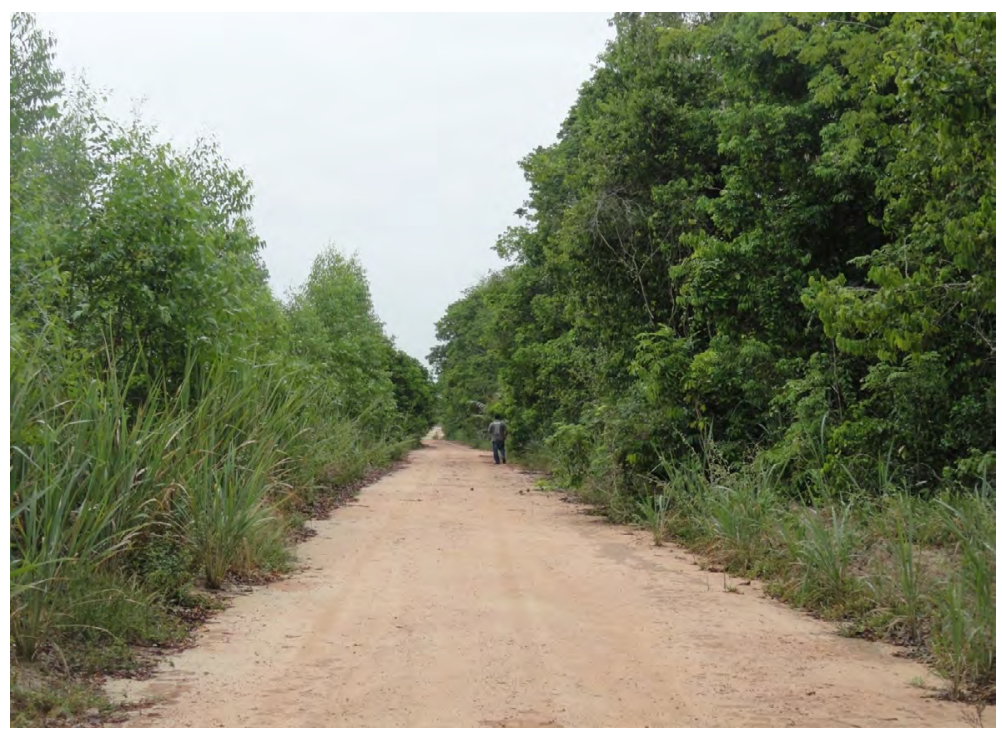

São Mateus, ES: fragmento florestal em estágio médio de regeneração, inserido em uma matriz de floresta de eucalipto e há 35 anos em regeneração, localizado a 500 metros da floresta fornecedora de propágulos 


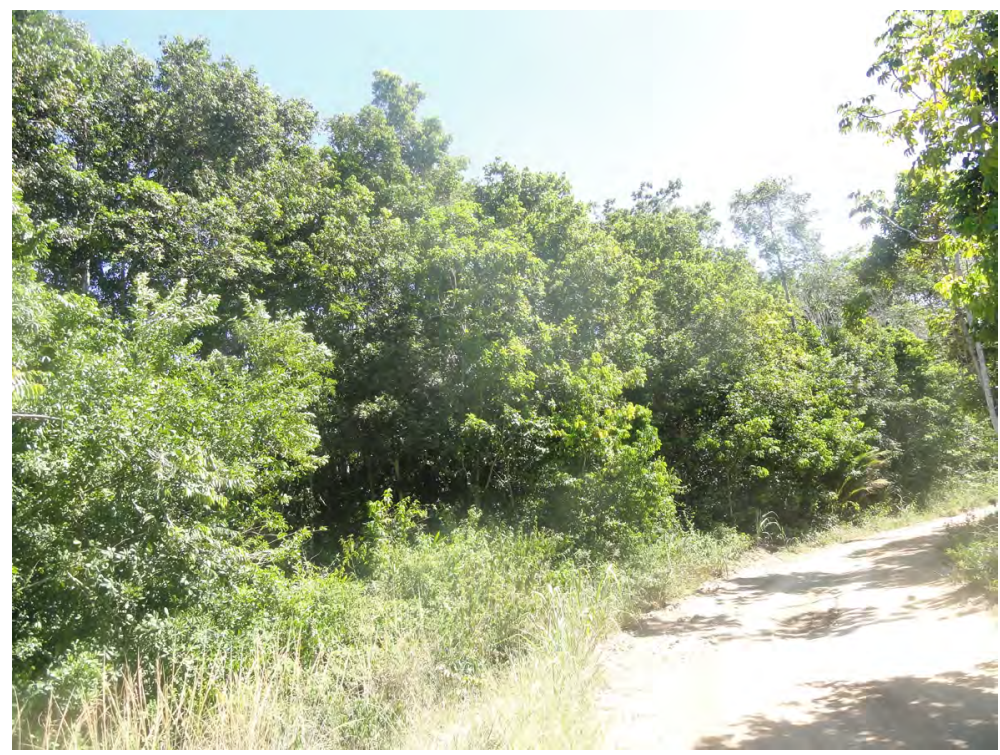

São Mateus, ES: fragmento florestal em estágio médio de regeneração e anexo à floresta fornecedora de propágulos

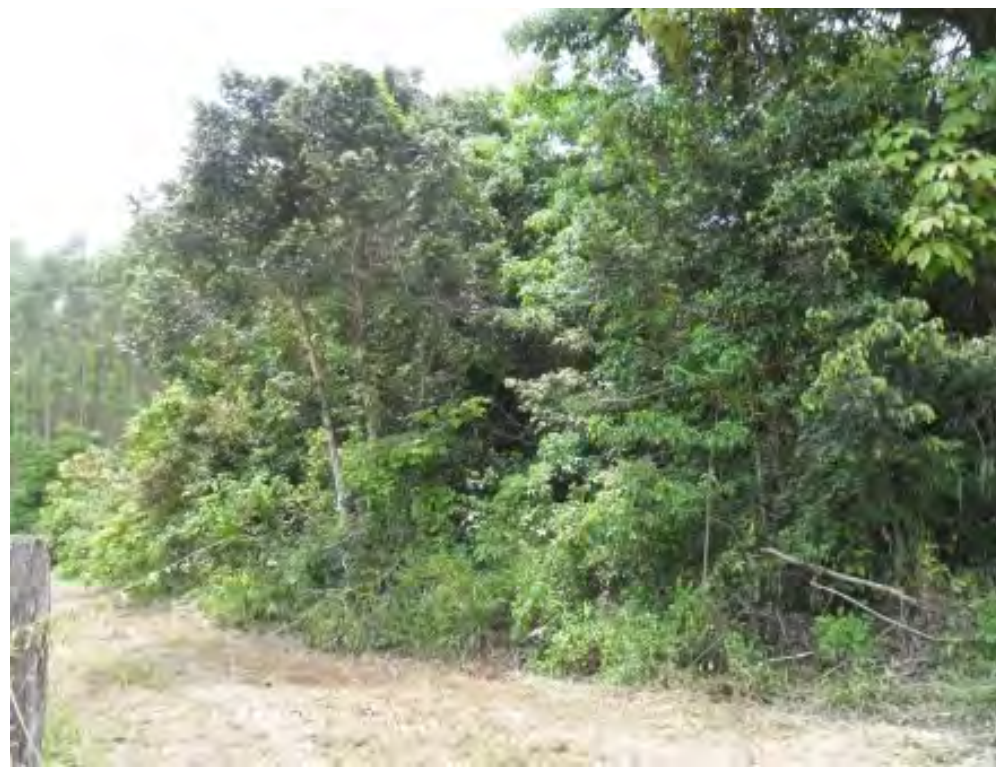

Aracruz, ES: fragmento florestal em estágio médio de regeneração, a 650 metros da floresta fornecedora de propágulos, com 25 anos de regeneração e ocupado anteriormente, durante 20 anos, por culturas agrícolas 


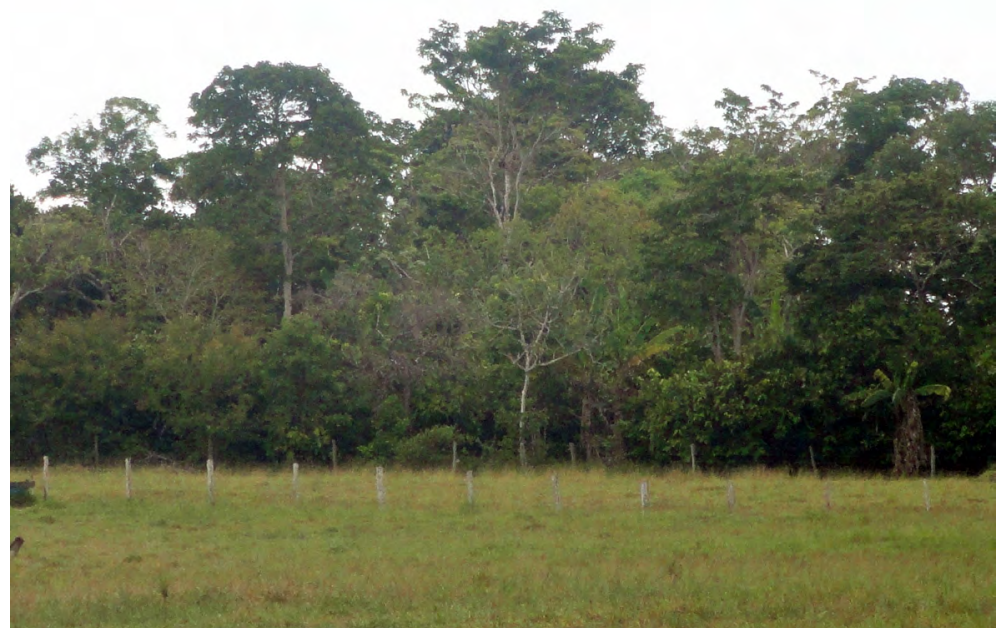

Linhares, ES: fragmento florestal em estágio médio de regeneração, a 870 metros da floresta fornecedora de pro1págulos, com 30 anos de regeneração e ocupado anteriormente, durante mais de 20 anos, por culturas agrícolas

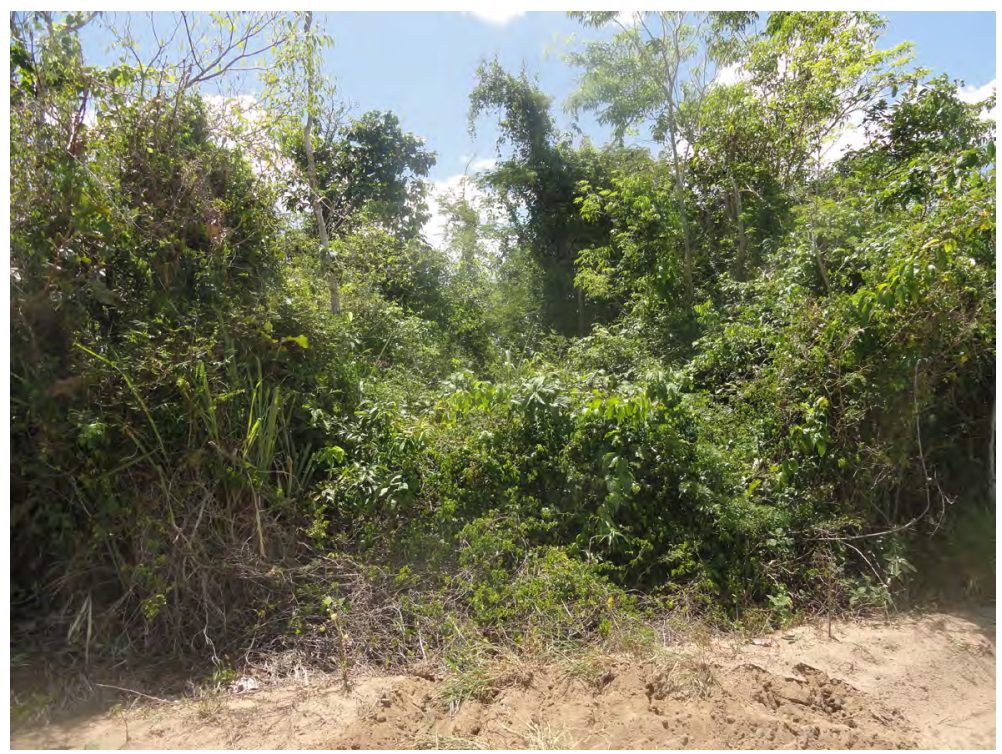

Linhares, ES: fragmento florestal em estágio médio de regeneração, a 350 metros da floresta fornecedora de propágulos, com mais de 20 anos de regeneração e ocupado anteriormente, durante 20 anos, por culturas agrícolas 


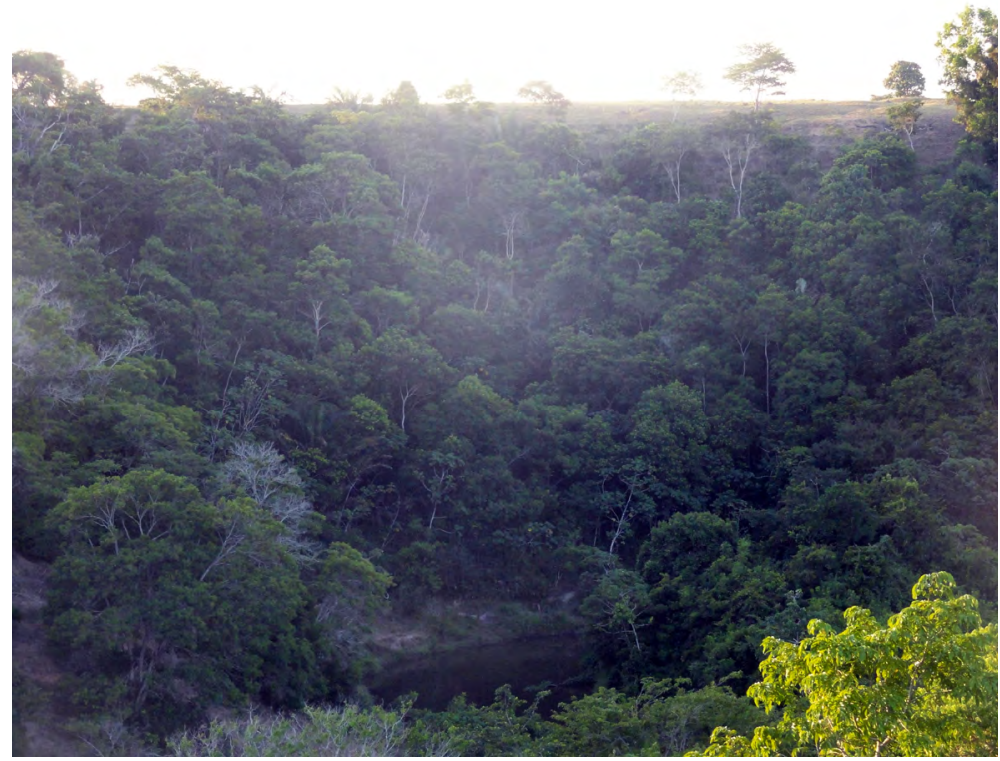

Pedro Canário, ES: fragmento florestal em estágio médio de regeneração

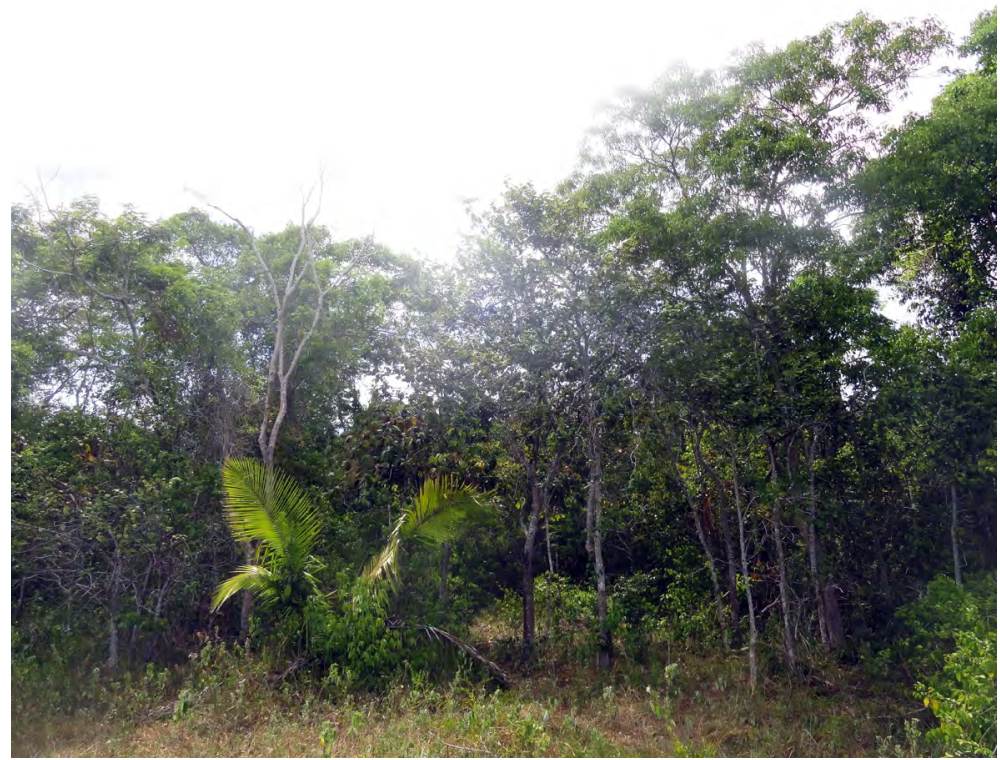

Nova Venécia, ES: fragmento florestal em estágio médio de regeneração, anexo à floresta fornecedora de propágulos, com 30 anos de regeneração e ocupado anteriormente, durante 20 anos, por culturas agrícolas 


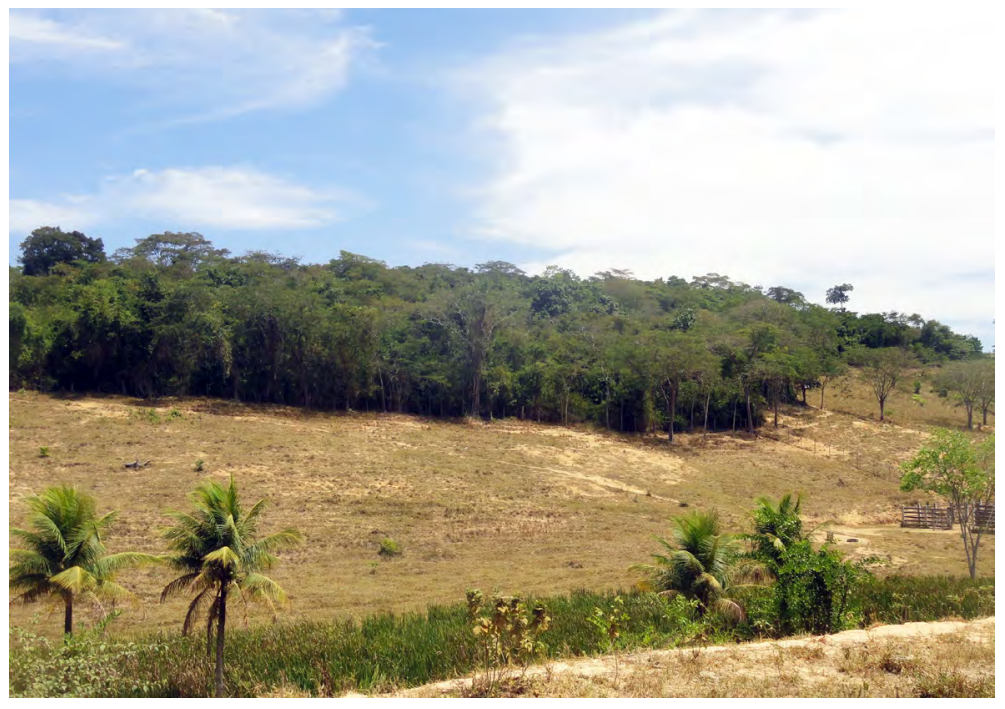

Vila Pavão, ES: fragmento florestal em estágio médio de regeneração, a 200 metros da floresta fornecedora de propágulos, com 30 anos de regeneração e ocupado anteriormente, durante 20 anos, por culturas agrícolas

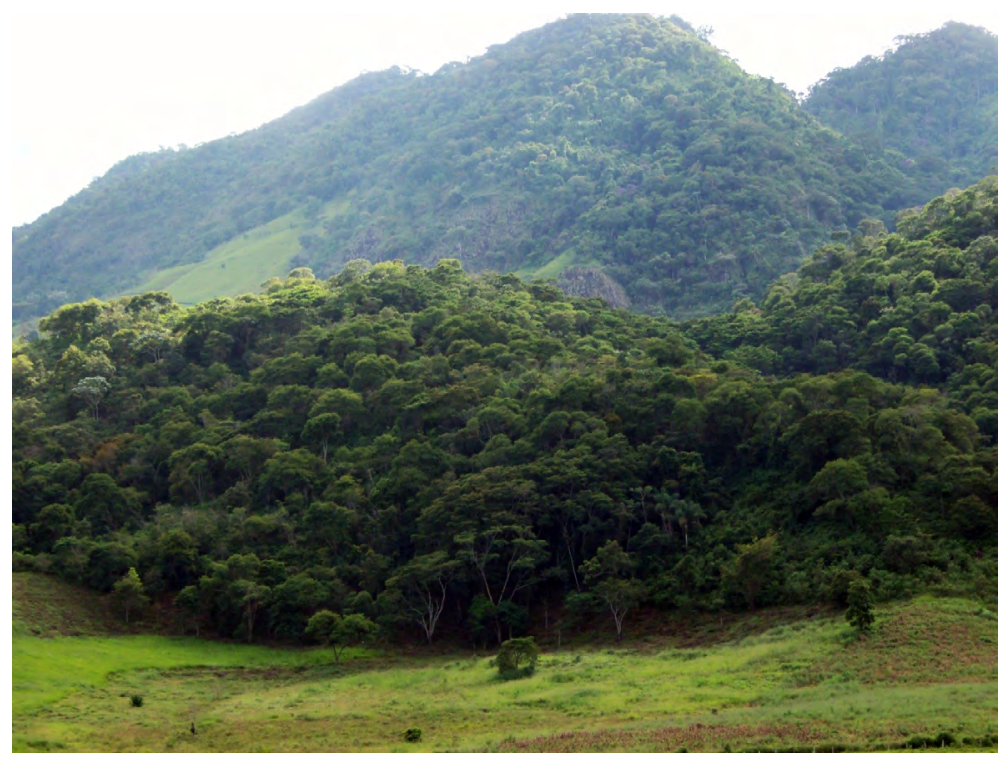

Guaçuí, ES: fragmento florestal em estágio médio de regeneração (à frente), localizado a 250 metros e abaixo da floresta fornecedora de propágulos (atrás), com 12 anos de regeneração e ocupado anteriormente, durante mais de 30 anos, por café 


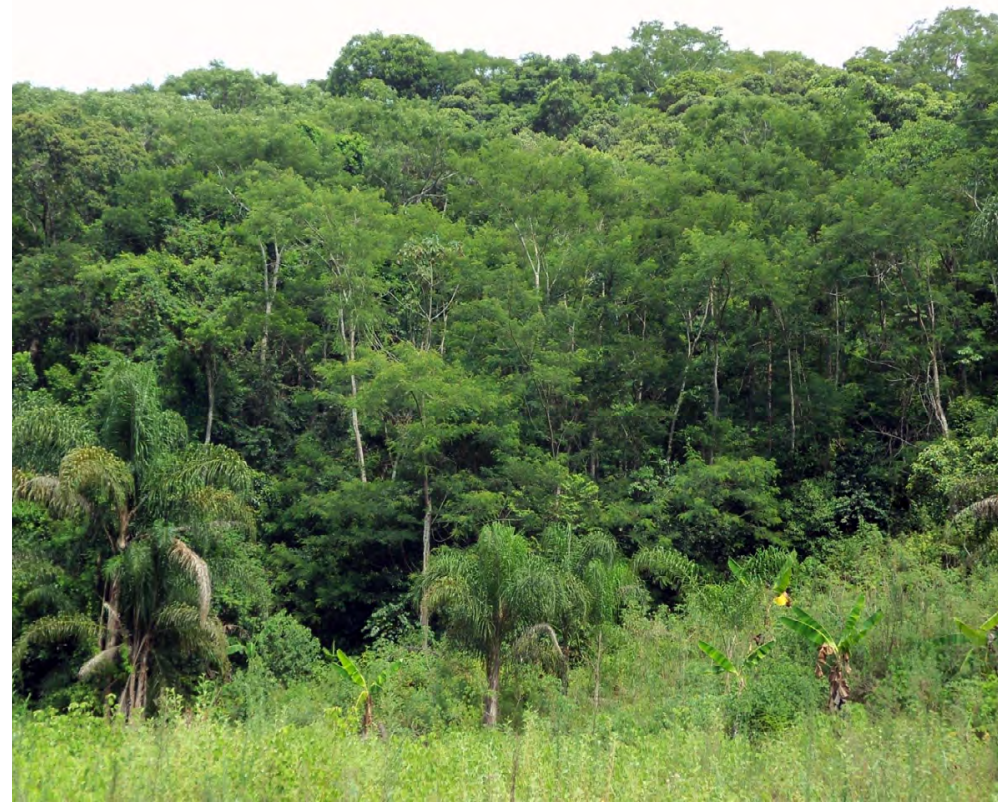

Domingos Martins, ES: fragmento florestal em estágio médio de regeneração

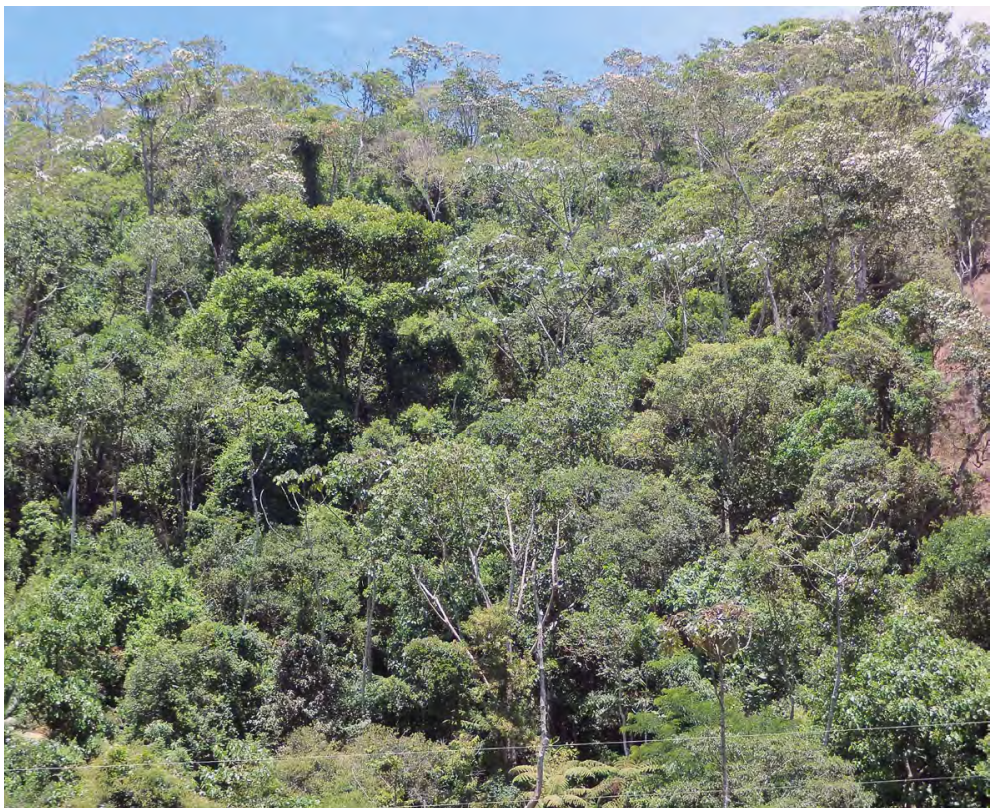

Domingos Martins, ES: fragmento florestal em estágio médio de regeneração 


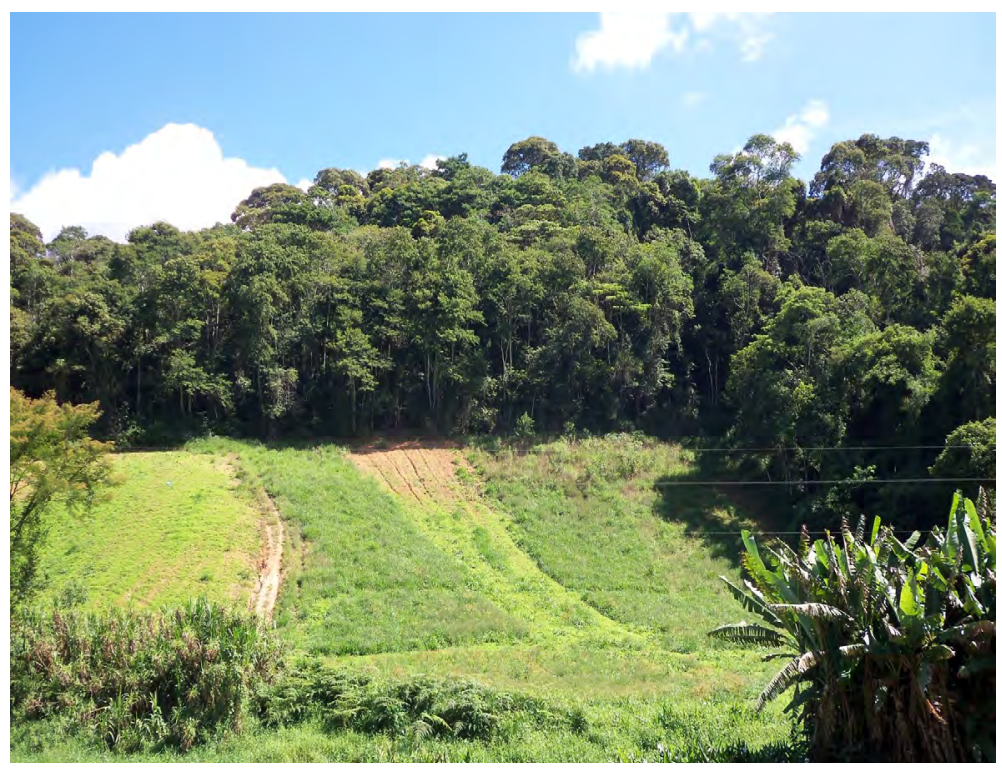

Domingos Martins, ES: fragmento florestal em estágio médio de regeneração, anexo à floresta fornecedora de propágulos, com 12 anos de regeneração e ocupado anteriormente, durante 30 anos, por pasto

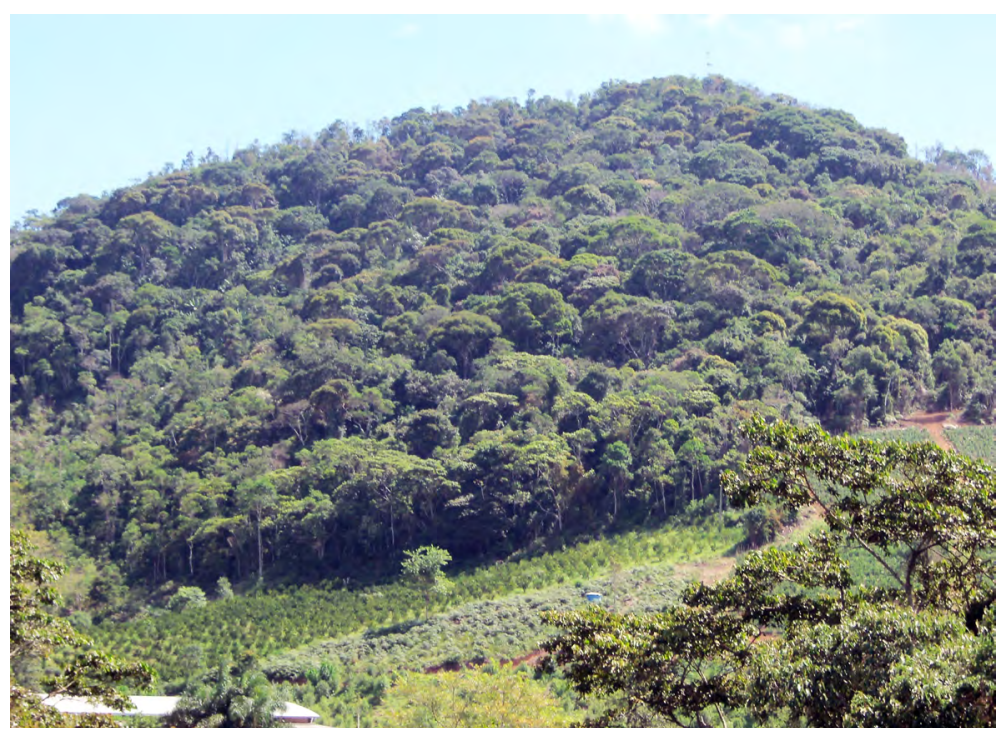

Domingos Martins, ES: fragmento florestal em estágio médio de regeneração, anexo à floresta fornecedora de propágulos, com 13 anos de regeneração e ocupado anteriormente, durante 20 anos, por pasto 


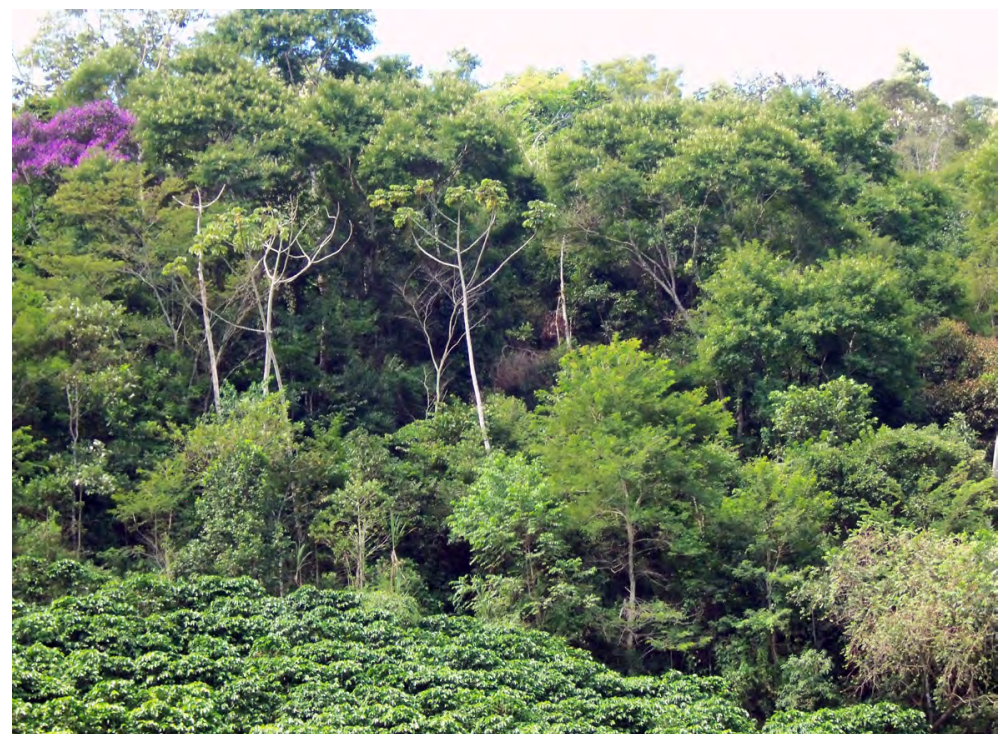

Venda Nova do Imigrante, ES: fragmento florestal em estágio médio de regeneração, anexo à floresta fornecedora de propágulos, com 20 anos de regeneração e ocupado anteriormente, durante mais de 20 anos, por pasto

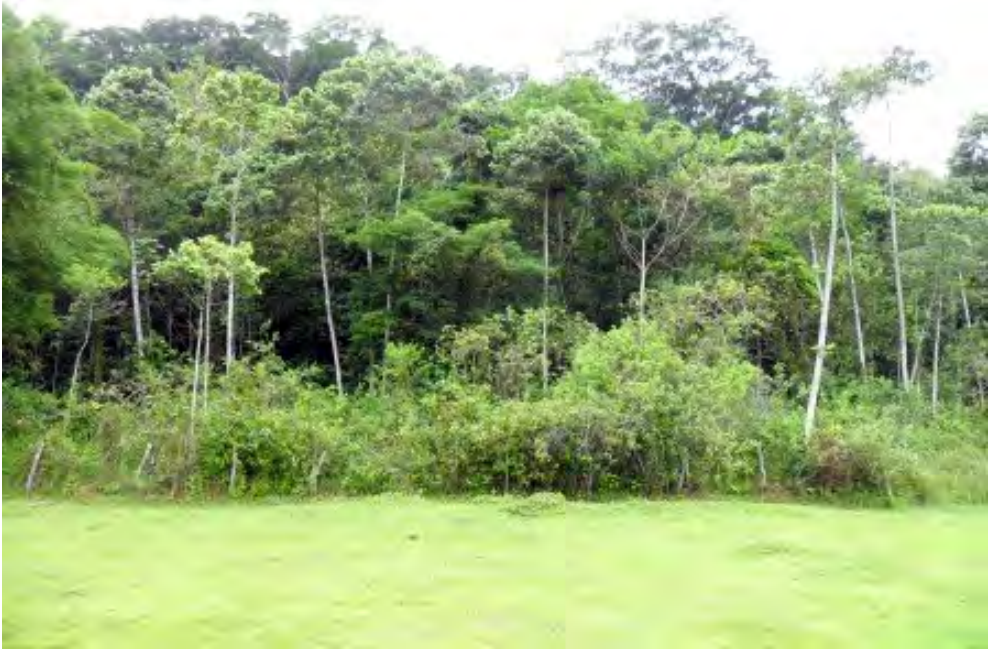

Cariacica, ES: fragmento florestal em estágio médio de regeneração, a 600 metros da floresta fornecedora de propágulos, com 35 anos de regeneração e ocupado anteriormente, durante mais de 10 anos, pela cultura da banana 


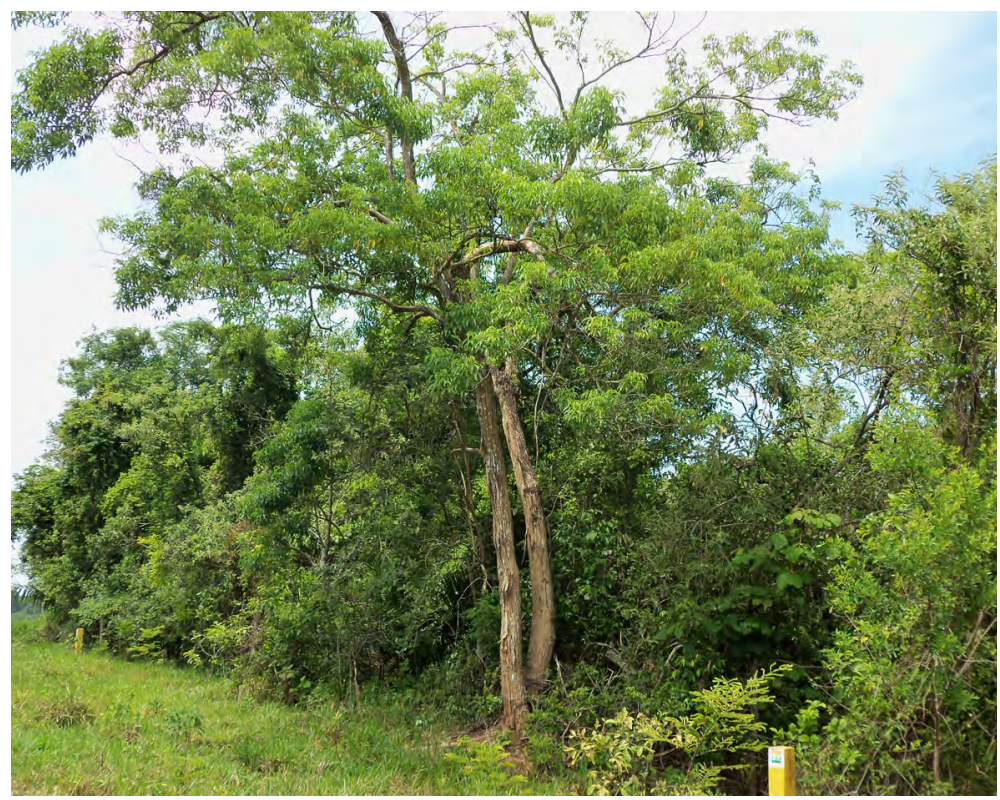

Guarapari, ES: fragmento florestal em estágio inicial/transição estágio médio de regeneração, anexo à floresta fornecedora de propágulos

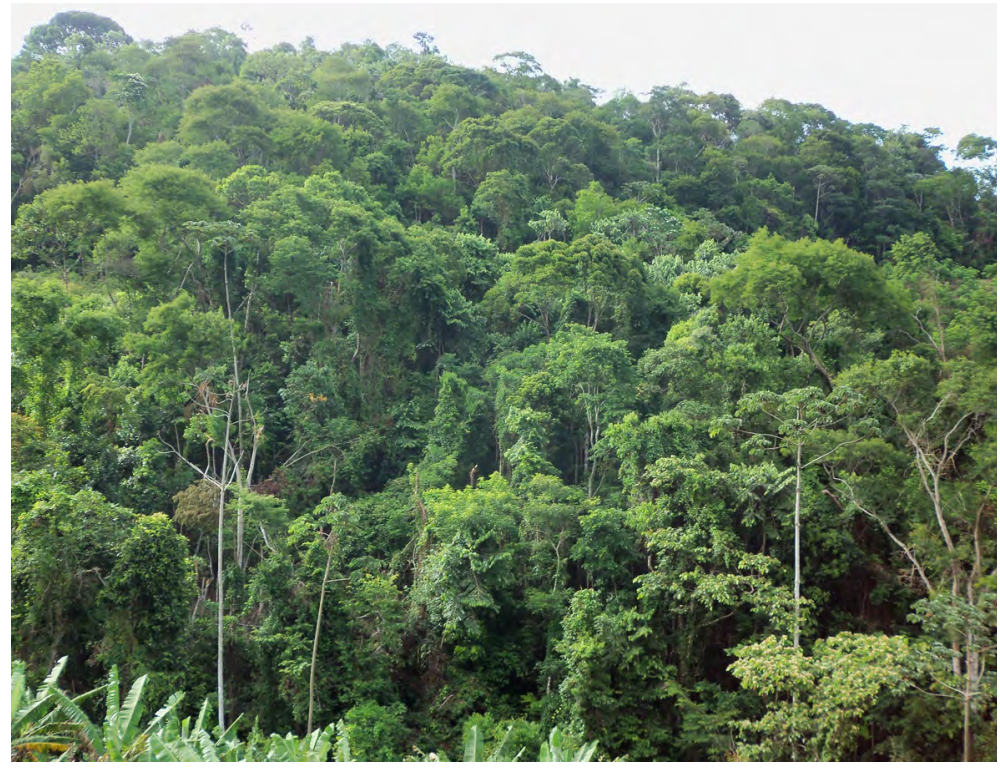

Guarapari, ES: fragmento florestal em estágio inicial/transição estágio médio de regeneração, anexo à floresta fornecedora de propágulos 


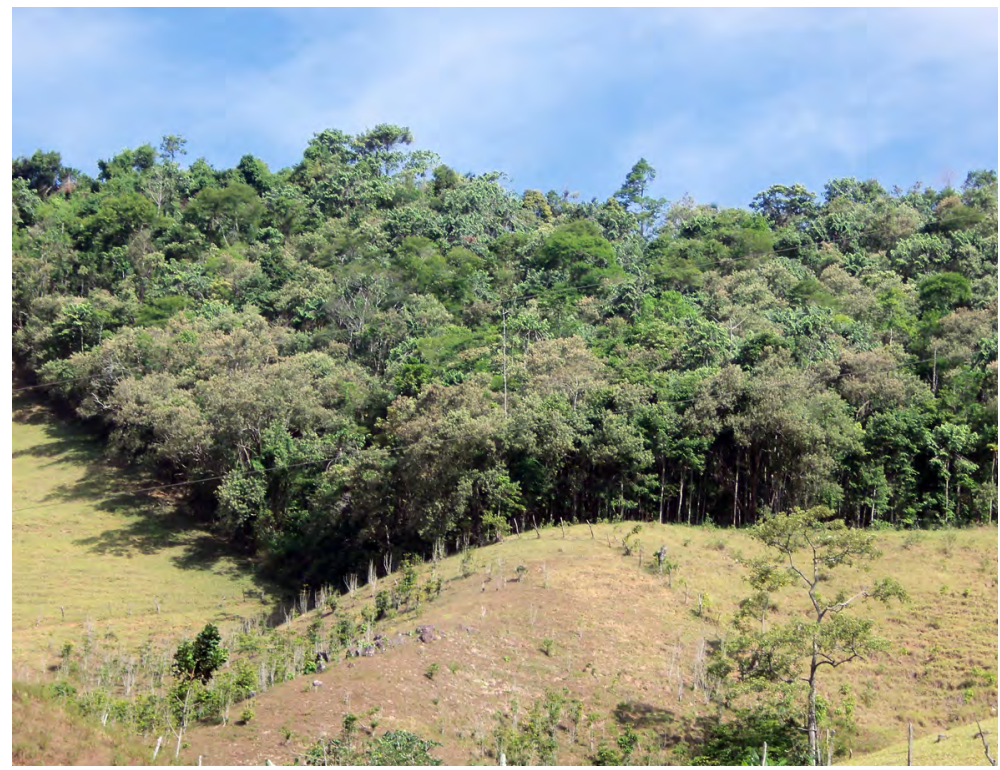

Guarapari, ES: fragmento florestal em estágio inicial/transição estágio médio de regeneração, a 470 metros da floresta fornecedora de propágulos

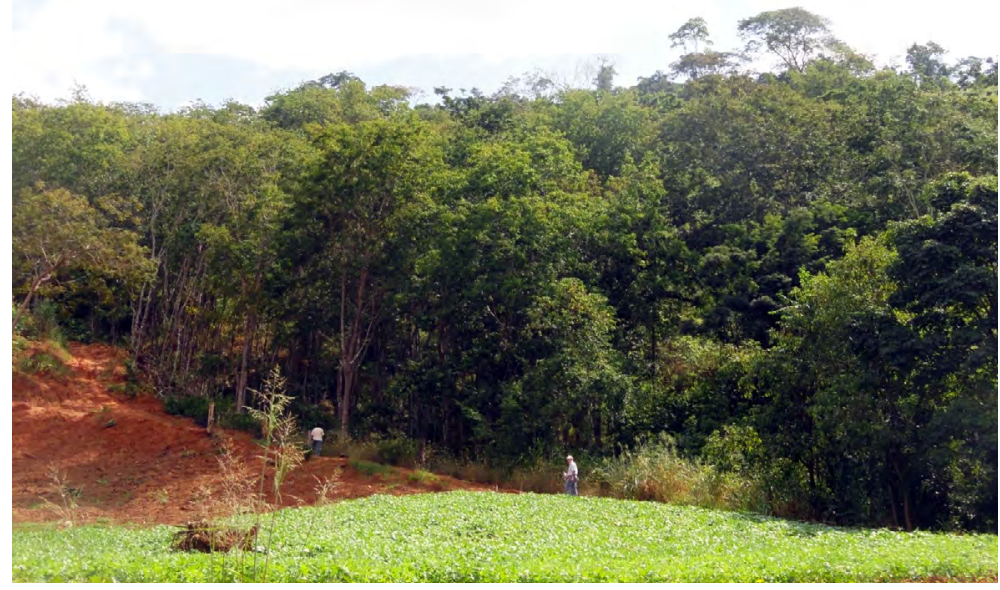

Laranja da Terra, ES: fragmento florestal em estágio médio de regeneração, anexo à floresta fornecedora de propágulos, com 15 anos de regeneração e ocupado anteriormente, durante 20 anos, por café 


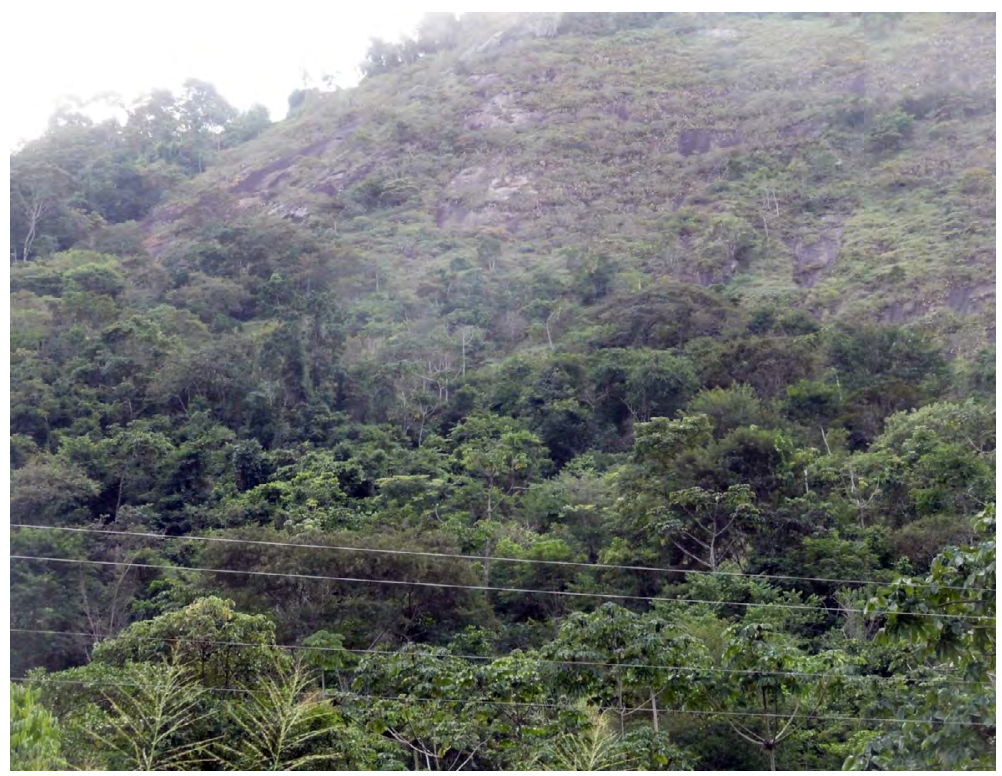

Itarana, ES: fragmento florestal em estágio médio de regeneração, a 250 metros da floresta fornecedora de propágulos, com 15 anos de regeneração e ocupado anteriormente, durante mais de 35 anos, por café

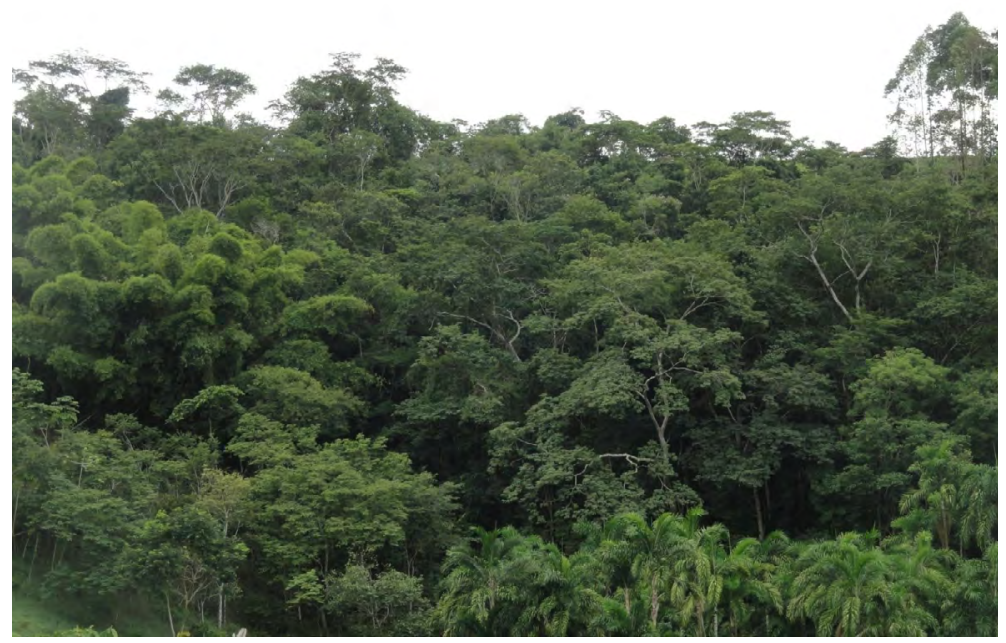

São Gabriel da Palha, ES: fragmento florestal em estágio médio de regeneração, a 400 metros da floresta fornecedora de propágulos e há 30 anos em regeneração 


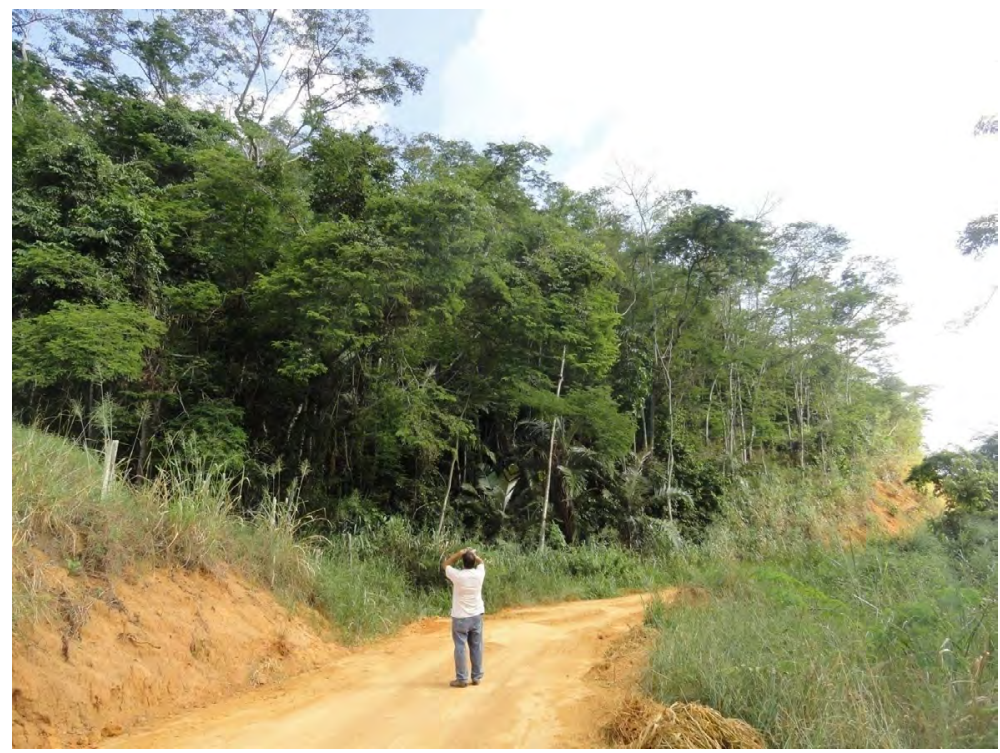

Itaguaçu, ES: fragmento florestal em estágio médio de regeneração, anexo à floresta fornecedora de propágulos, com 25 anos de regeneração e ocupado anteriormente, durante 30 anos, por pastagem

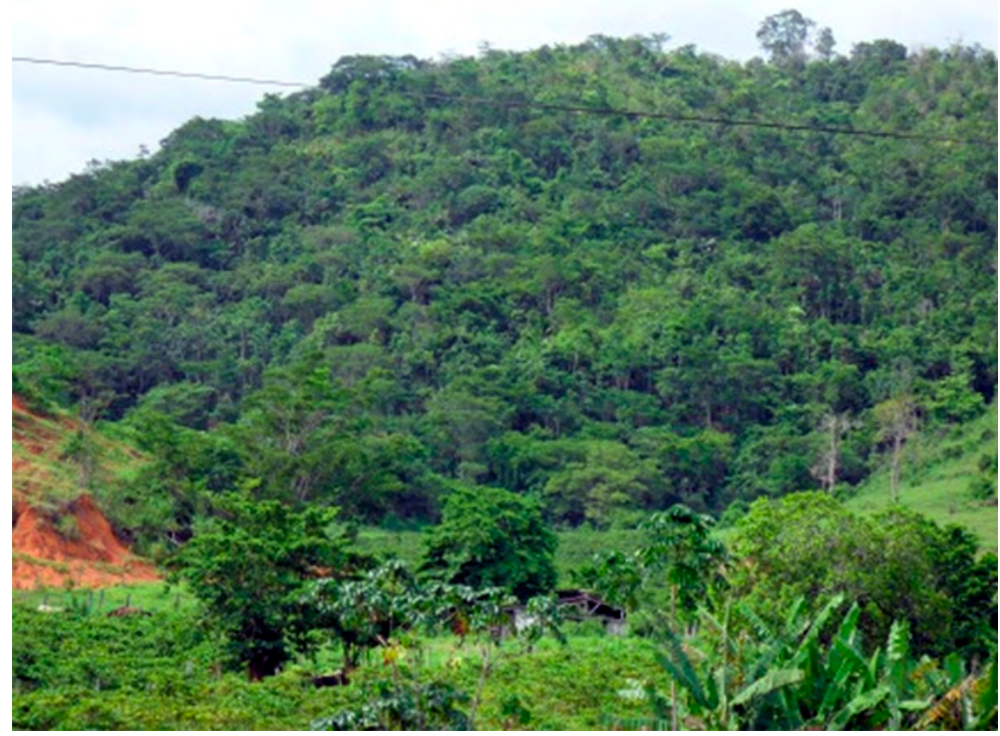

Colatina, ES: fragmento florestal em estágio médio de regeneração, com 15 anos de regeneração e ocupado anteriormente, durante 20 anos, por pastagem 


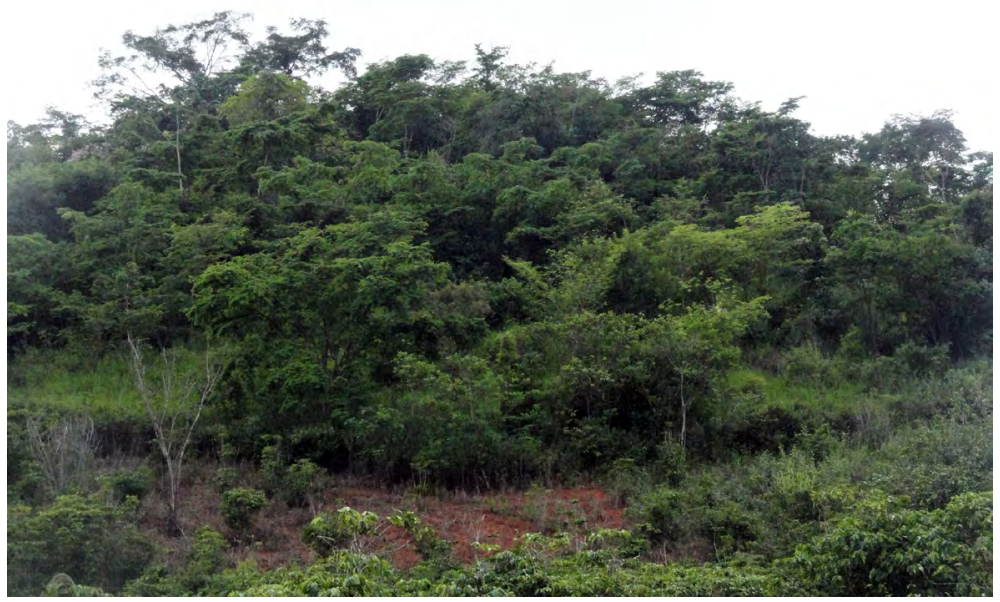

Pancas, ES: fragmento florestal em estágio médio de regeneração, a 650 metros da floresta fornecedora de propágulos, com 15 anos de regeneração e ocupado anteriormente, durante mais de 20 anos, por pasto

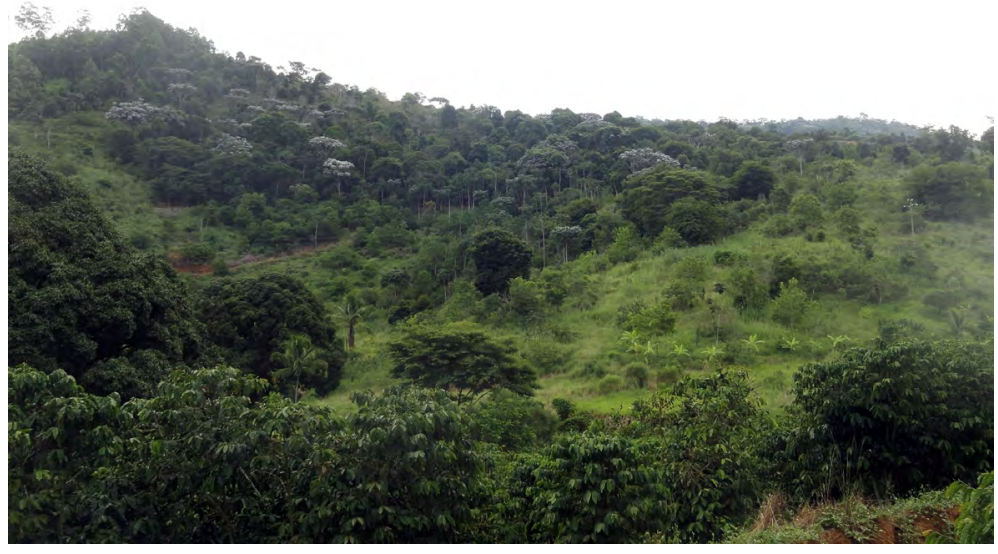

Pancas, ES: fragmento florestal em estágio médio de regeneração, a 800 metros da floresta fornecedora de propágulos, com 15 anos de regeneração e ocupado anteriormente, durante mais de 40 anos, por café 


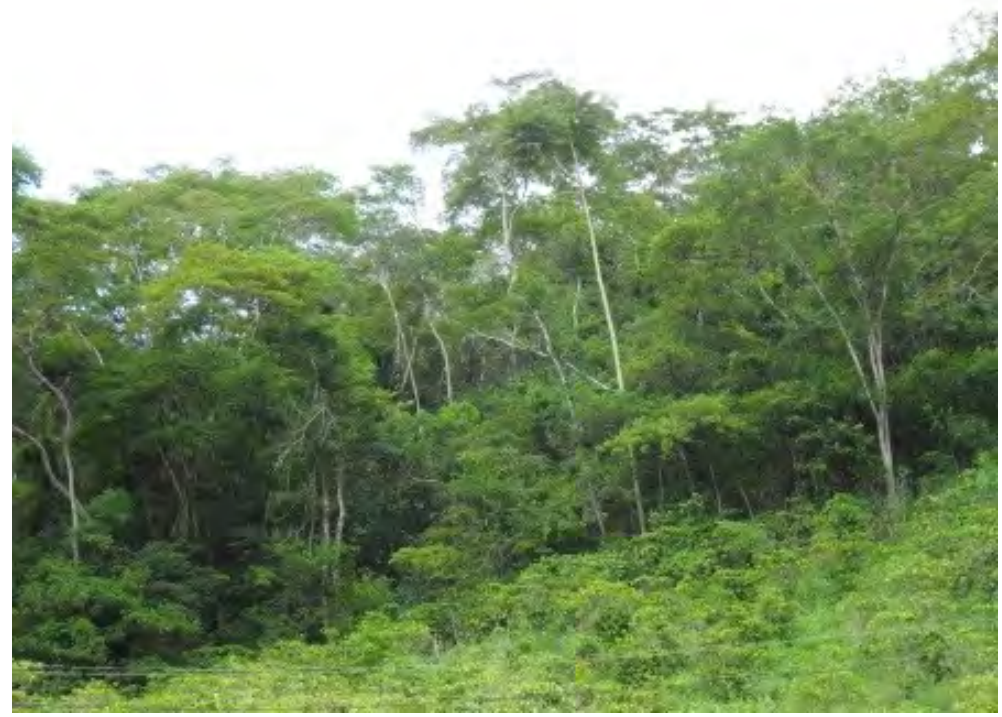

Colatina, ES: fragmento florestal em estágio médio de regeneração, com alta frequência de ocorrência de angico, a 600 metros da floresta fornecedora de propágulos, com 21 anos de regeneração e ocupado anteriormente, durante 60 anos, por pastagem

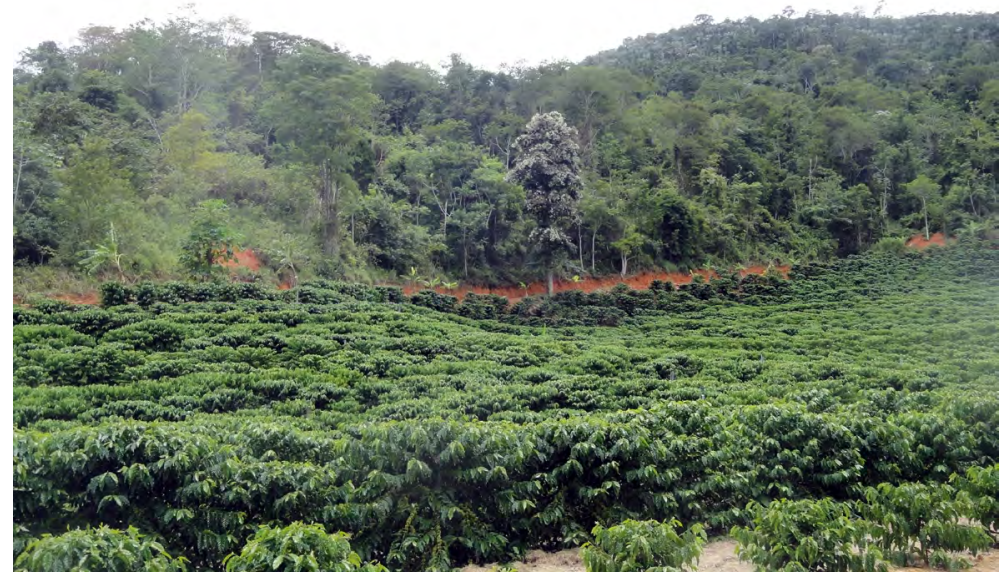

Marilândia, ES: fragmento florestal em estágio médio de regeneração, anexo à floresta fornecedora de propágulos, com 30 anos de regeneração e ocupado anteriormente, durante 20 anos, por café 


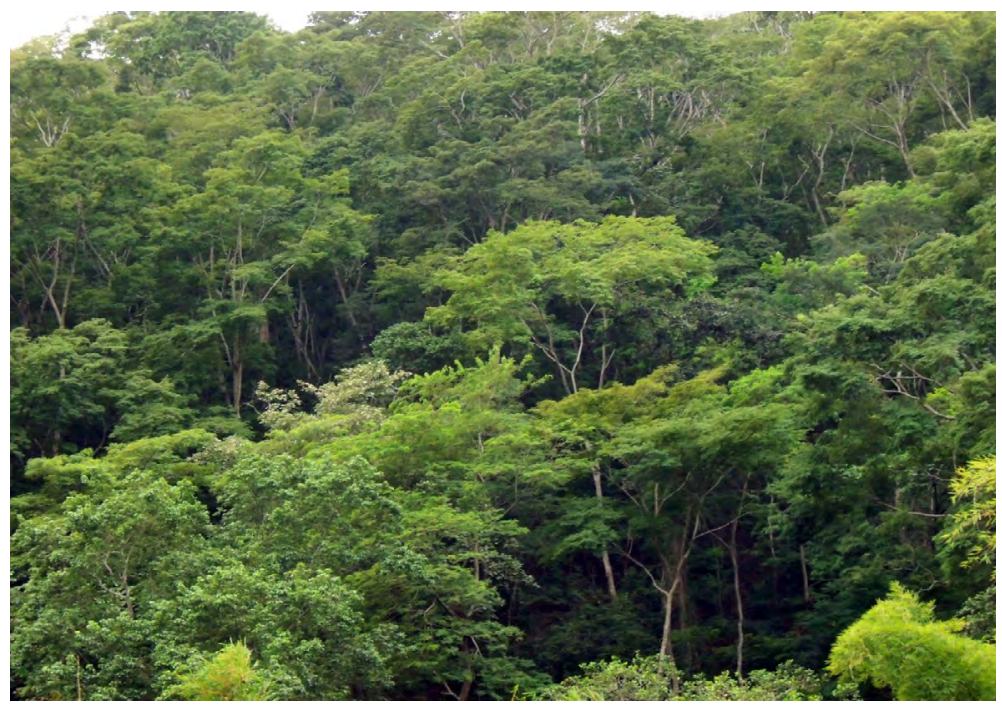

Atílio Vivácqua, ES: fragmento florestal em estágio médio de regeneração, com alta frequência de ocorrência de angico, anexo à floresta fornecedora de propágulos, com 30 anos de regeneração e ocupado anteriormente, durante mais de 20 anos, por culturas agrícolas

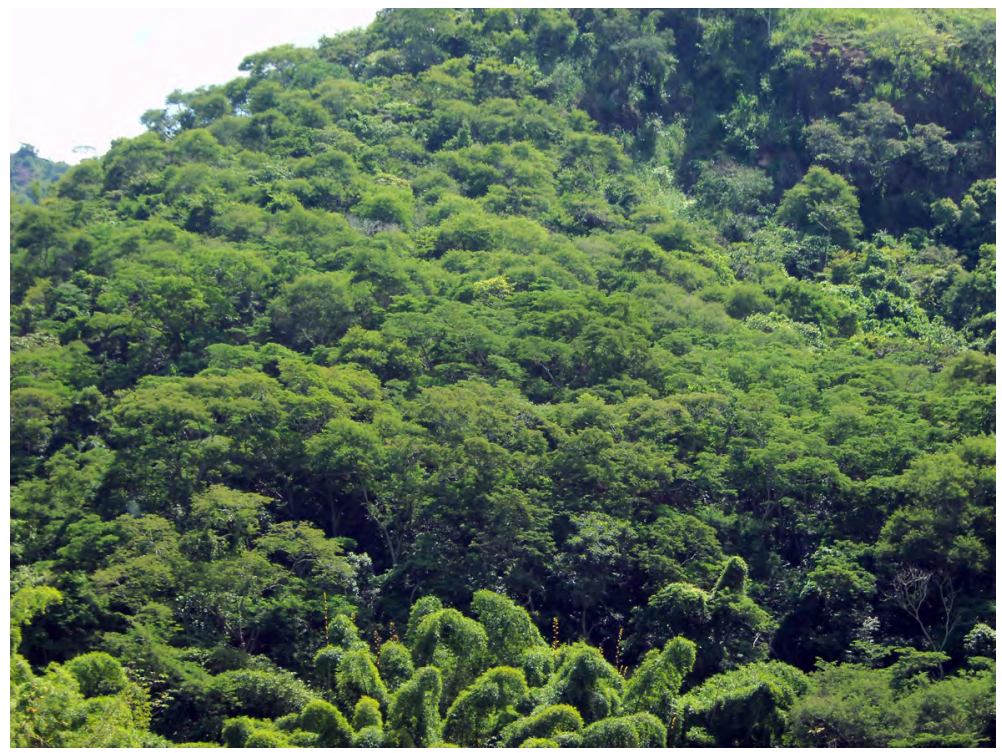

Bom Jesus do Norte, ES: fragmento florestal em estágio médio de regeneração, a 450 metros da floresta fornecedora de propágulos, com 30 anos de regeneração e ocupado anteriormente, durante mais de 20 anos, por café 


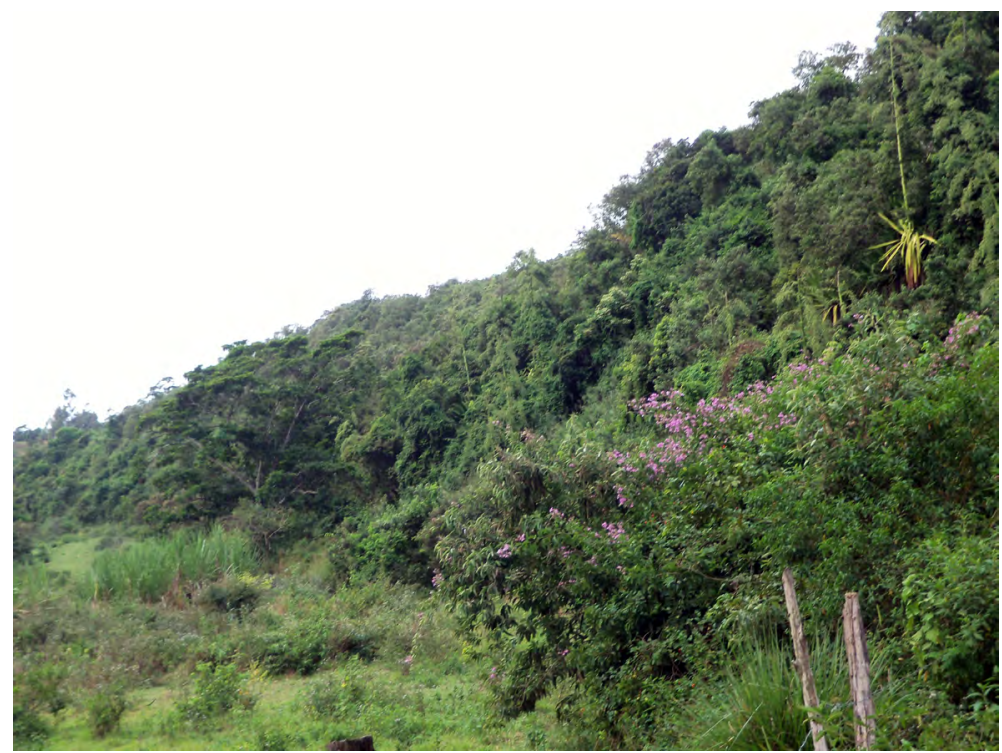

Itapemirim, ES: fragmento florestal em estágio médio de regeneração, a 600 metros da floresta fornecedora de propágulos, com 25 anos de regeneração e ocupado anteriormente, durante mais de 20 anos, por cana-de-açúcar

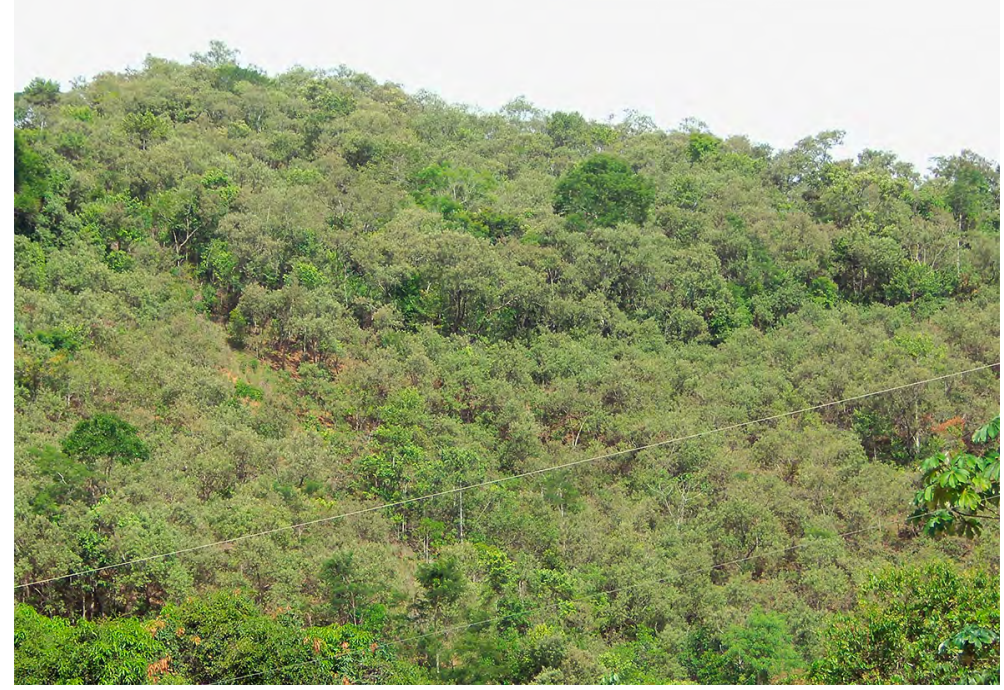

Itapemirim, ES: fragmento florestal em estágio inicial de regeneração, apresentando monodominância do camará, a 500 metros da floresta fornecedora de propágulos, com 10 anos de regeneração e ocupado anteriormente, durante mais de 20 anos, por culturas agrícolas 


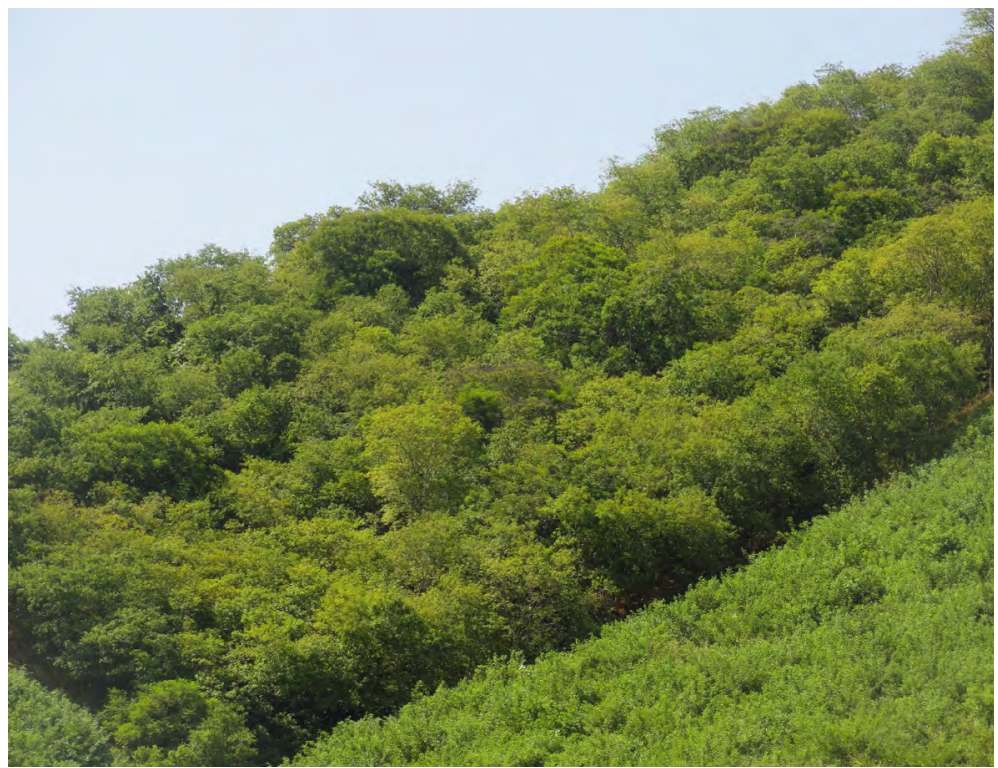

Baixo Guandu, ES: floresta em estágio inicial, apresentando monodominância da espécie aroeira

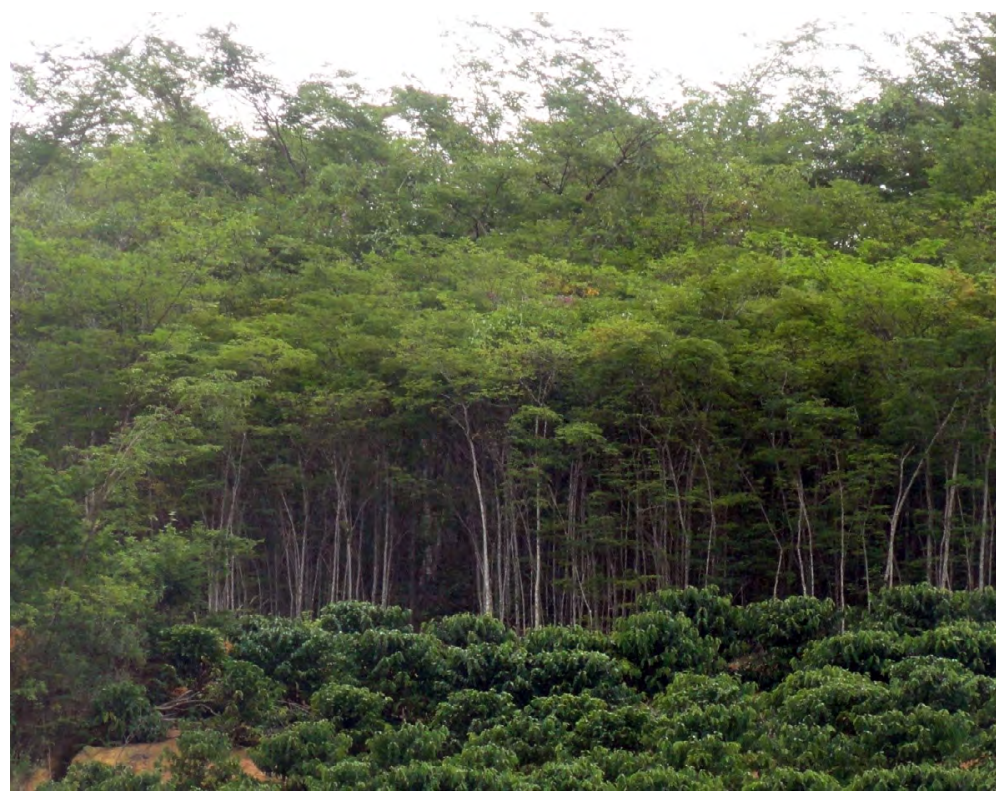

Marilândia, ES: fragmento florestal em estágio inicial de regeneração, apresentando monodominância da espécie falso-jacarandá 


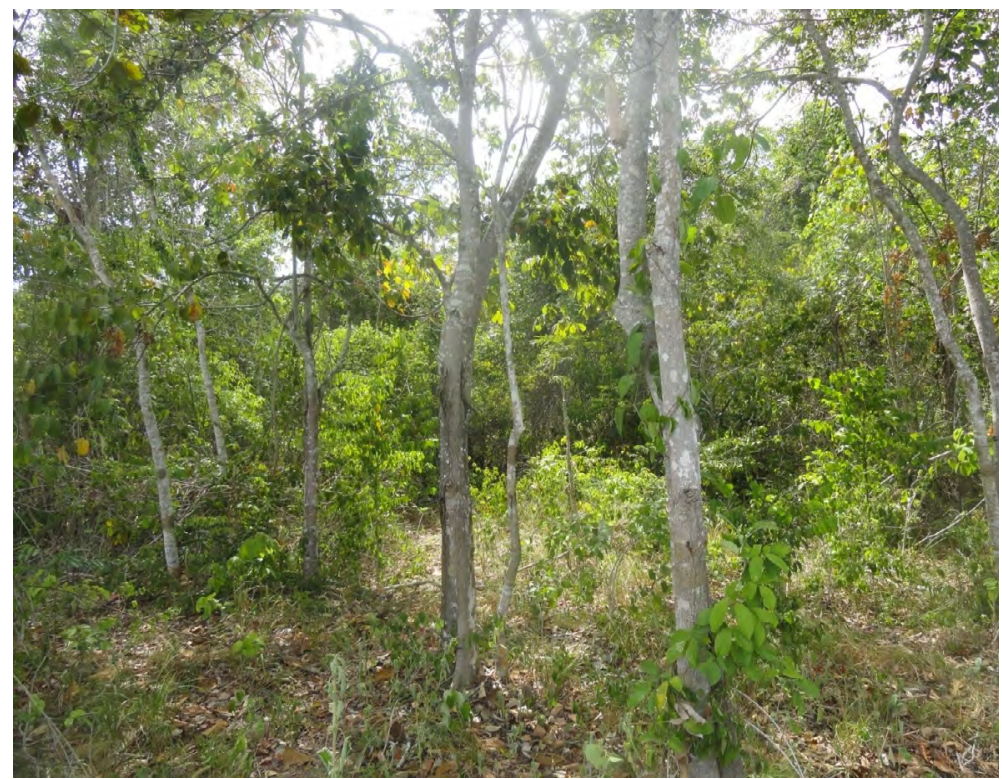

Nova Venécia, ES: fragmento florestal em estágio médio de regeneração, demonstrando o sub-bosque com forte impacto pelo pastoreio de bovinos

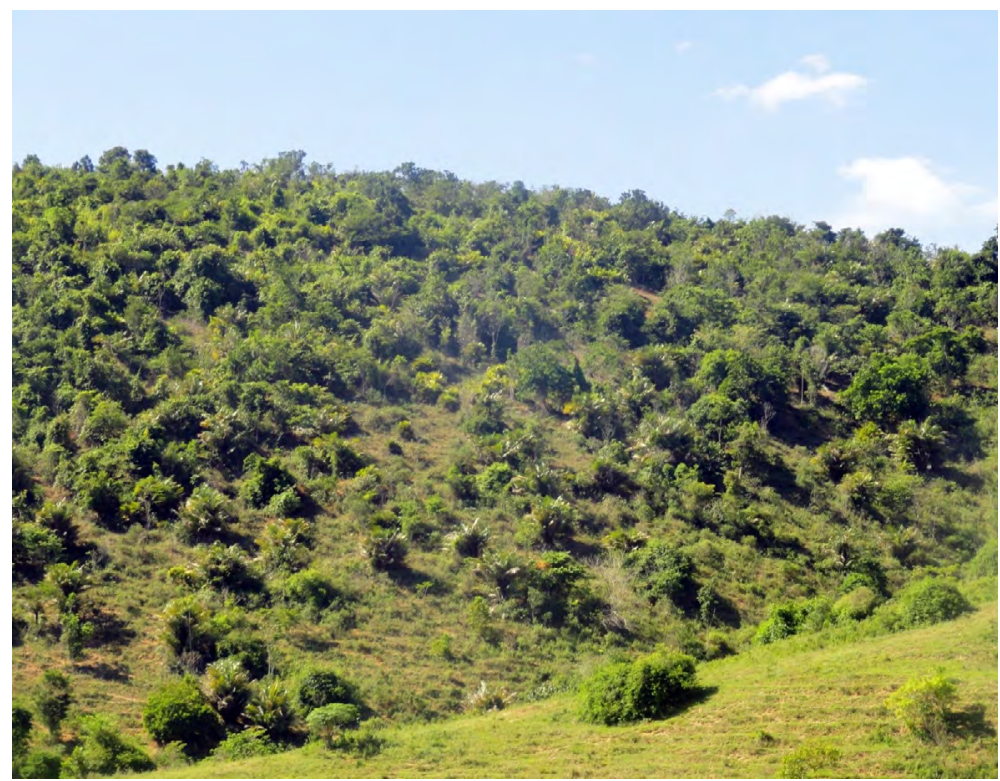

Ecoporanga, ES: área ocupada por espécies do grupo ecológico das pioneiras, demonstrando o início da regeneração natural 


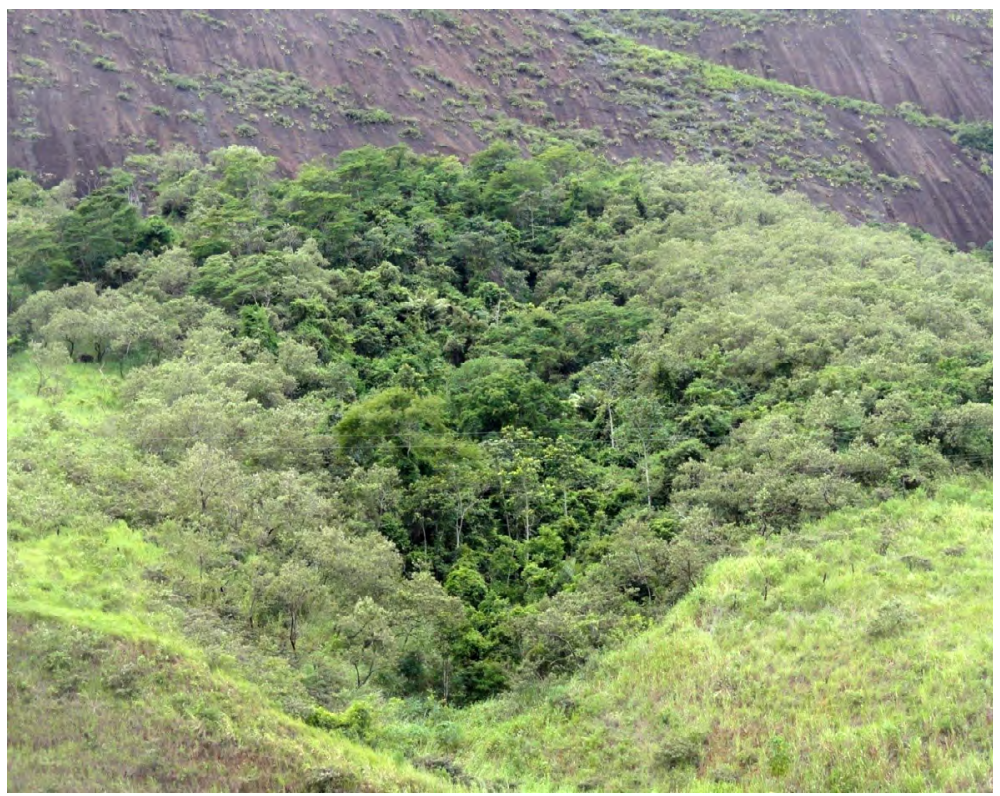

Ibiraçu, ES: fragmento florestal em regeneração, com tipologias diferentes associadas à condição pedoclimática

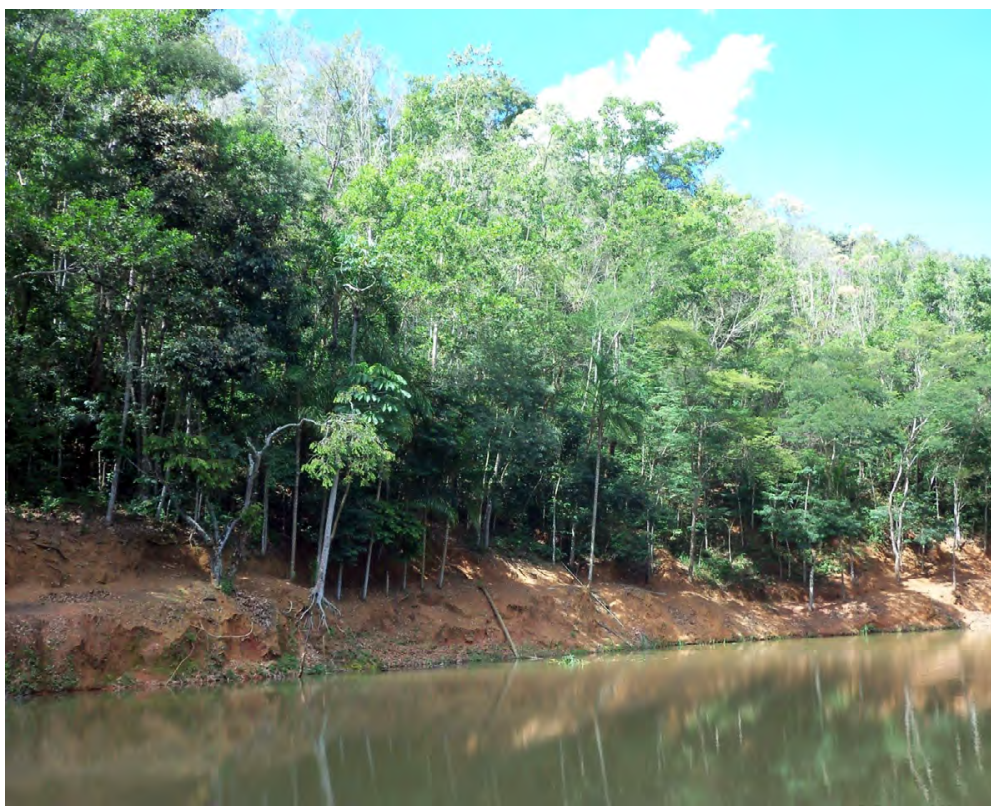

Venda Nova do Imigrante, ES: floresta ciliar plantada há 20 anos 


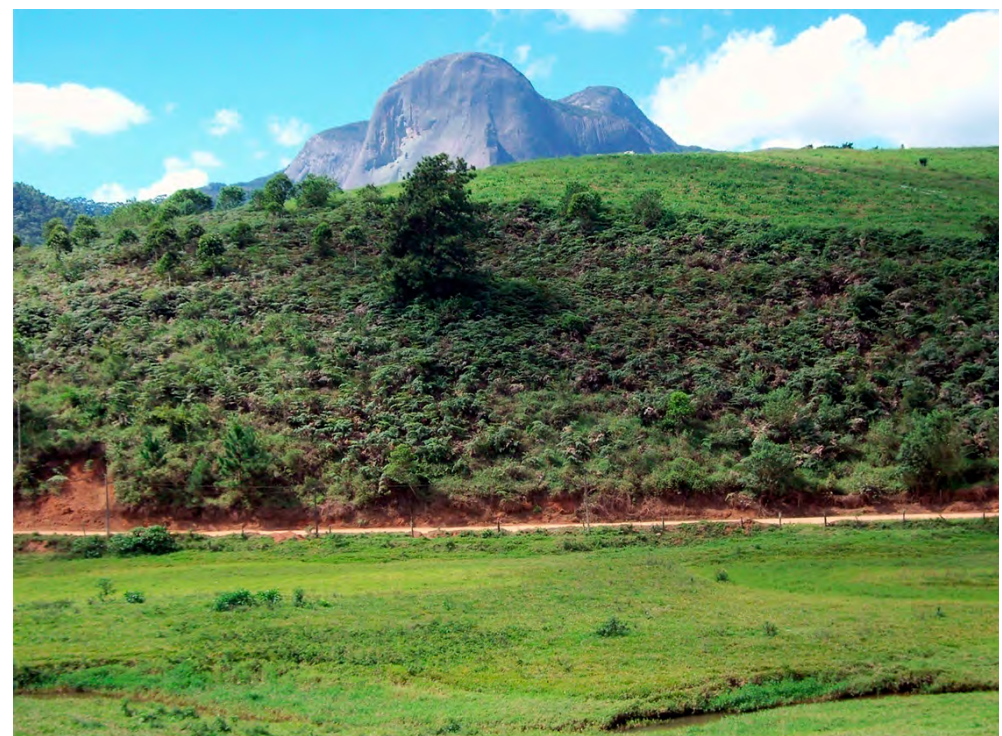

Pedra Azul/Domingos Martins, ES: área ocupada por samambaia, considerada uma espécie-problema para a regeneração natural de florestas

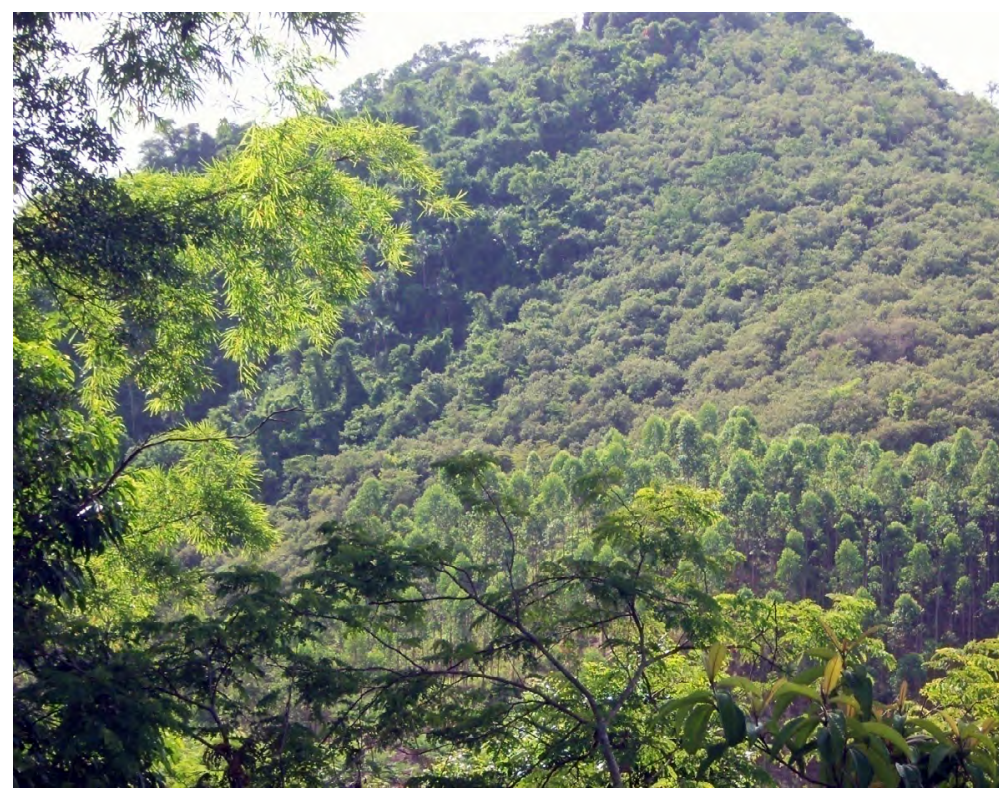

Domingos Martins, ES: fragmento florestal em estágio inicial/médio de regeneração, anexo à floresta fornecedora de propágulos, com dominância da espécie camará e há 20 anos em regeneração 


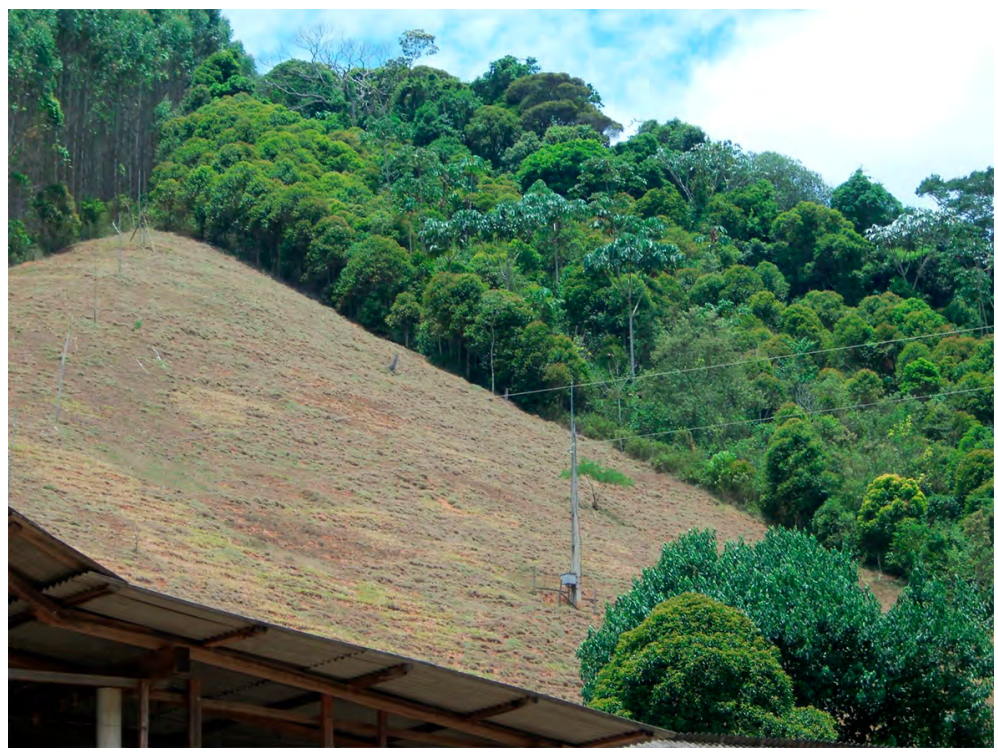

Domingos Martins, ES: fragmento florestal em estágio inicial de regeneração, anexo à floresta fornecedora de propágulos (matriz), com 5 anos de regeneração e ocupado anteriormente, durante 20 anos, por café 


\section{Sobre os autores}

\section{Marcelo Simonelli}

Biólogo. Mestre em Botânica. Professor do Ifes - Campus Vitória.

\section{Sebastião Venâncio Martins}

Engenheiro Florestal. Mestre em Ciência Florestal. Doutor em Botânica. Professor e Coordenador do LARF - Laboratório de Restauração Florestal - UFV -Viçosa, MG.

\section{Mário Sartori}

Geógrafo/Cartógrafo. Aposentado do Idaf. Professor Ufes.

\section{Frederico Lopes Raposo Filho}

Engenheiro Agrônomo. Mestre em Biologia Vegetal.

\section{Gilmar Dadalto}

Engenheiro Agrônomo. Mestre em Solos. Aposentado do Incaper/ Seag, Coordenador Técnico Cedagro.

\section{Marcos Lima Pereira}

Engenheiro Florestal. Mestre em Ciências Florestais. 
